
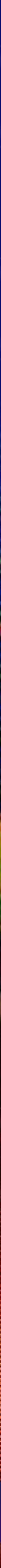


\section{Editor-in-Chief}

prof. Maria Kicheva, Ph.D., SWU “Neofit Rilski”, Bulgaria

\section{Deputy Chief Editor}

Vladislav Krastev, Ph.D., SWU “Neofit Rilski”, Bulgaria

\section{Editorial Board}

prof. Paul Leonard Gallina,

Ph.D., Williams School of Business, Bishop's University Sherbrooke, Québec, Canada

prof. José António Conceição Santos,

The School of Management, Hospitality and Tourism of the University of Algarve, Portugal

prof. Preslav Dimitrov, Ph.D.,

SWU "Neofit Rilski”, Bulgaria

prof. Dimitar Dimitrov, Ph.D.,

SWU “Neofit Rilski”, Blagoevgrad, Bulgaria

assoc. prof. Nikolay Marin, Ph.D.,

SWU “Neofit Rilski”, Blagoevgrad, Bulgaria

assoc. prof. Yuliana Mladenova Mateeva, Ph.D.,

Varna Free University, Bulgaria

assoc. prof. Andriyana Andreeva, Ph.D.,

University of Economics - Varna, Bulgaria

prof. dr of Economic Sc. Stanka Tonkova,

University of National and World Economy, Bulgaria

prof. Gancho Ganchev, Ph.D.,

SWU “Neofit Rilski”, Bulgaria

assoc. prof. Almaz Kadyraliev, Ph.D.,

Musa Ruskulbekov Kyrgyz Economic University

assoc. prof. dr. of Economic Sc. Bakas Bakhtiyar uulu,

Musa Ruskulbekov Kyrgyz Economic University

assoc. prof. Tran Van Hoa, Ph.D.,

Hue University, Vietnam

assoc. prof. Truong Tan Quan, Ph.D.,

Hue University, Vietnam

Pham Xuan Hung, Ph.D.,

Hue University, Vietnam

prof. Farhad Sariev, Ph.D.,

K. Tynystanov Issyk-Kul State University, Kyrgyzstan 
prof. Maksat Erkimbaev, Ph.D.,

K. Tynystanov Issyk-Kul State University, Kyrgyzstan

assoc. prof Svetlana Sirmbard, Ph.D.,

Adam University, Kyrgyzstan

prof. dr. of Technical Sc. Abdyrakhman Subankulovich Mavlyanov, Adam University, Kyrgyzstan

prof. dr. of Economic Sc. Almakuchukov Keneshbek Mukashevich, Adam University, Kyrgyzstan

assoc. prof. Dimitris Aidonis, Ph.D.,

Technological Educational Institute of Central Macedonia at Serres assoc. prof. Dimitris Folinas, Ph.D.,

Technological Educational Institute of Central Macedonia at Serres

chief. assist. prof. Petar Parvanov, Ph.D.,

SWU “Neofit Rilski”, Bulgaria

chief. assist. prof. Katarina Valaskova, Ph.D.,

University of Zilina, Slovakia

chief. assist. prof. Pavol Durana, Ph.D.,

University of Zilina, Slovakia

prof. Bistra Vasileva, Ph.D.,

University of Economics - Varna

assoc. prof. Desislava Serafimova, Ph.D.,

University of Economics - Varna

assoc. prof. Hristina Blagoycheva, Ph.D.,

University of Economics - Varna

\section{$\underline{\text { Production Editors }}$}

Chief Assist. Prof. Blagovesta Koyundzhiyska-Davidkova, Ph.D., SWU "Neofit Rilski”, Bulgaria

Chief Assist. Prof. Ivanka Vasenska, Ph.D., SWU “Neofit Rilski”, Bulgaria 


\section{CONTENT}

THE EFFECT OF AGGREGATE INSTITUTIONAL QUALITY ON FOREIGN DIRECT INVESTMENT IN NIGERIA: EVIDENCE FROM NARDL

Musa Abdullahi Sakanko

James Obilikwu

Joseph David

THE LESSONS LEARNED FROM THOMAS COOK FAILURE. IS IT BREXIT?

p. 14

\section{Doaa Salman}

Dina Seiam

IMPORTANCE OF THE MARKETING ENVIRONMENT ANALYSIS IN THE PROCESS OF STRATEGIC MARKETING DECISION MAKING

Dilyana Yaneva

EGYPTIAN FEMALE ENTREPRENEURSHIP AS DRIVING FACTORS IN THE DIGITAL ERA,

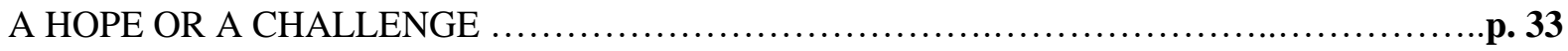

Doaa Salman

Abeer Rashdan

Layla Amr

THE IMPACT OF OTA - TRANSFORMING CONTEMPORARY TOURISTS'

INTENTIONS

Ivaylo Ivanov

FORECASTING OF SOME KEY INDICATORS OF THE RFI AND RFP PROCESSES OF THE BULGARIAN MOBILE TELECOMMUNICATION OPERATORS .p. 62 Avgustin Milanov

THE LIABILITY OF THE STATE FOR DAMAGE CLAIMS RESULT OF VIOLATION OF THE EUROPEAN UNION LAW ..p. 71

Veselina Kanatova-Buchkova 


\title{
THE EFFECT OF AGGREGATE INSTITUTIONAL QUALITY ON FOREIGN DIRECT INVESTMENT IN NIGERIA: EVIDENCE FROM NARDL
}

\author{
MUSA ABDULLAHI SAKANKO ${ }^{1}$ \\ JAMES OBILIKWU ${ }^{2}$ \\ JOSEPH DAVID 3
}

\begin{abstract}
The vital role of foreign direct investment has been widely studied and documented in the economic literature; however, the argument remains largely on identifying the main determinants of FDI to developing countries. It is on this note, the quantitative research method was adopted to investigates the asymmetric relationship between aggregate institutional quality and foreign direct investment in Nigeria using the Nonlinear Autoregressive Distributive Lag (NARDL) model on quarterly time-series data from 1999 Q1-2019 Q4. The bounds test obtains revealed that long-run co-integrating relationship exist among the variables. The NARDL result shows that both in the short-run and long-run aggregate institutional quality have asymmetric and a statistically significant effect on foreign direct investment. The study recommends that the government should establish or strengthen the quality of institutional indicators and legal framework to assure confidence in the system to motivate Foreign Direct Investment (FDI) inflow.
\end{abstract}

Keywords: foreign direct investment, institutional quality, NARDL

JEL Codes: F23, B52, C32

\section{Introduction}

The rising episodes of foreign direct investment (FDI) in less developed countries play a vital role while includes the provision of investment capital inflow, mobilization of savings, job creation, revenue generation, acquisition of modern technologies, enhancing foreign exchange, competition and productivity, local content and manpower developing thus, stimulation of economic growth. These advantages are not unknown to policymakers but due to the liberal of the economy and policies, the inflow of FDI in less developed countries is characterizing with incentive packages offering to encourage foreign investors (Esew \& Yaroson, 2014).

This study attempts to examine the asymmetric effect of institutional quality on FDI in Nigeria, as the quality of institutions, is the backbone and pillars of FDI's inflow, whereas, weak institutions insert uncertainty to the foreign investors because investment decisions are volatile to uncertainty. Therefore, globalization comes with many incentives that drive economic growth and development, one of them is FDI's and numerous factors encourage its inflow, among is institutional quality. For example, sound institutional qualities entice and

\footnotetext{
${ }^{1}$ Department of Economics, University of Jos, Nigeria. Sakanko2015@gmail.com

ORCID iDhttps://orcid.org/0000-0002-5203-5462

${ }^{2}$ Department of Economics, Ibrahim Badamasi Babangida University, Nigeria

ORCID iDhttps://orcid.org/0000-0001-6265-8906

${ }^{3}$ Department of Economics, Ibrahim Badamasi Babangida University, Nigeria. ORCID iDhttps://orcid.org/0000-0002-1357-5618
}

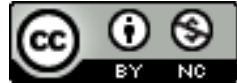

This work is licensed under a Creative Commons Attribution-NonCommercial 4.0 International License. 
convince foreign investors (Esew \& Yaroson, 2014) as it ensures a certain level of a property right to the investors and lesser cost for doing business whilst inefficient institution quality feature with mistrust, high levels of extortion, corruption, bureaucracy, marginal and fear of sunk costs.

Quite some time, Nigeria's FDI net inflow percentage of Gross Domestic Product, which grew from $4.28 \%$ to $4.85 \%$ and $5.79 \%$ in 1989, 1993, and 1994 respectively, declined to $2.83 \%$ in 2005 and later rose to $2.93 \%$ in 2009 , after which dropped to $1.66 \%$ in 2010 and further dropped to one time lowest $0.5 \%$ and $0.4 \%$ in 2018 and 2019 respectively (World Bank, 2019). Figure 1 below shows an overview chart of Nigeria's net inflow of FDI from 2005 to 2019.

Figure 1: FDI net inflow in Nigeria

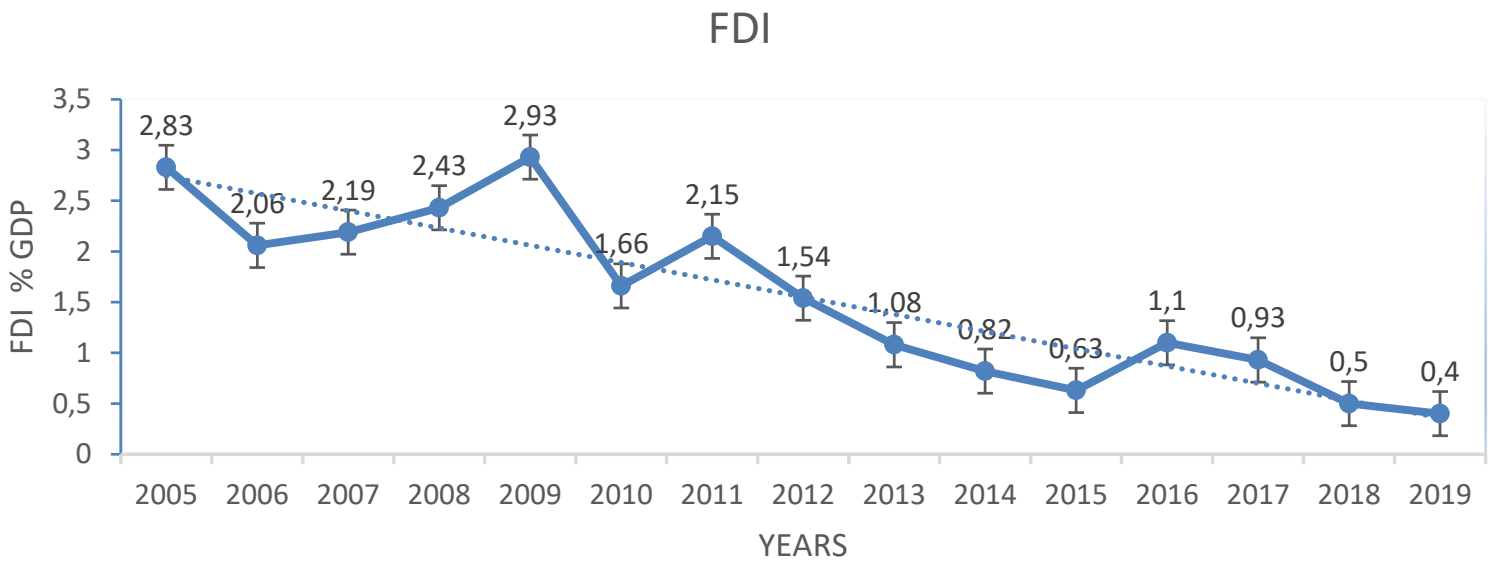

Source: World Bank (2019)

Figure 1 shows the FDI net inflow in Nigeria, over time has been seeping at a decreasing rate. The FDI net inflow was so substantial before the Democratic government in 1999 in Nigeria

This has awakened a skirmish among scholars, researchers, economists, political analysts, and policymakers as to what factors are responsible for the low attracting of FDI in the less developed countries, especially, Nigeria. Though, theoretical literature (Dunning, 1993) opined that market share or size, cheap labour force, governance efficiency or effectiveness and seeking resources are the motives for investing in foreign markets while Oke, Ezike \& Ojogbo (2012) and Ajide, Adeniyi \& Raheem (2014) suggest that obtaining political stability, control of corruption, and government effectiveness were the major determinate of FDI. Similarly, Blomstrom, Lipsey, \& Zejan (1994), Balasubramanyam, Salisu, \& Sapsford (1996), Borensztein, De Gregorio, \& Lee (1998), Hermes \& Lensink (2003), Bengoa \& Sanchez-Robles (2003), Alfaro, Chanda, Kalemli-Ozcan, \& Sayek (2004), Javorcik (2004), Azman-Saini, Law \& Ahmad (2010), Havranek \& Irsova (2011) and Gönel \& Aksoy (2016) ascertained that level of economic development, financial markets development, human capital, economic stability, trade liberalization, technology gap, FDI ownership and information, and communication technologies are influencing factors of FDI. Furthermore, in an aggregate study of institution quality Busse \& Hefeker (2007), Daude \& Stein (2007), Ali, Fiess, \& MacDonald (2010), Buchanan, Le \& Rishi (2012) and Jilenga \& Helian (2017) pinpointed that institutional failure is the determinant of FDI which has given room for other numerous maladies. Therefore, the fundamental principle underlines the paramount of institutional quality in appealing foreign direct investments to a country that is credited to what 
makes up these qualities. Besides, the institution quality has six components, therefore these indicators could differently influence FDI inflow (Esew \& Yaroson, 2014 and Omodero, 2019).

Given the above arguments, appraising the correlative between institutional qualities and FDI is significant. While different views still prevail in the literature, nonetheless, promising institutional qualities are linked to a higher inflow of FDI (Peres, Ameer \& Helian, 2018; Hayat, 2019; Fagbemi \& Bello, 2019). Certainly, despite the volume of rising contemporary perceptions concerning institutional quality and FDI, the available empirical studies in Nigeria investigate the individual effect of institutional indicators on FDI includes Esew \& Yaroson (2014), Akpo \& Hassan (2015), Brown \& Ibekwe (2018), Omodero (2019) and Zangina \& Hassan (2020). However, this study examines the asymmetric effect of aggregate institutional quality on FDI in Nigeria.

The objective of this study is to examine the effect of the aggregate institutional quality on FDI in Nigeria. Then, the study argued on two principal research hypotheses, that there is no asymmetric relationship between aggregate institutional quality and FDI. And the aggregate institutional quality has no effect on FDI.

The significance of this study is, the paper is among the first to use the aggregate institutional quality and measures its effect on FDI in Nigeria. In this regard, the findings of the study will enable specific assumptions or inferences to be drawn from the empirical outcomes by policymakers, researchers, economists, analysts, and business practitioners for further decision and policymaking.

This study contributes to the existing literature in the study area as follows. The paper used aggregate institutional quality i.e. all the six quality indicators were summed (control of corruption, political stability, and absence of violence, regulatory quality, rule of law, government effectiveness and voice and accountability). Secondly, previous studies assumed a linear relationship between institutional quality and FDI's except (Zangina \& Hassan, 2020), they used nonlinear ARDL model in Nigeria, yet on disaggregate institutional quality indicators (corruption), this study follows suit and evaluates nonlinear (positive and negative) corridors through which aggregate institutional quality might influence FDI in Nigeria because "macroeconomic variables are found to be nonlinear in most cases in social sciences" (Kahneman \& Tversky, 1979, p. 258; Shiller, 1993, p. 147). Thirdly, the annual time series data were converted to quarterly to overcome small sample size which has been a challenge for measurement of institution indicators and forced most of the previous studies to adopts panel study. Lastly, the asymmetric relationship exists between institutional quality and FDI's both in the short-run and long-run with significant absent only in the long-run.

Following the introductory section, section two is the literature review, section three methodology, section four the results and discussion, and section five conclusion and recommendations

\section{Literature review}

North (1991) affirmed that institutions are constraints developed by humans for economic, political, and social interaction. These institutions contain laws, customs, constitutions, and property rights that reduced uncertainty and order in society. That the environmental structure of institutions of a particular society provides firms with benefits to perform more efficiently. Similarly, Hayat (2019) substantiated that good institution feature certainty because of the prevailing rule of law, property right, and less corruption which can encourage technological transfer whereas week institutions deny rule of law and property rights, high corruption, and political instability thereby few inflows of the foreign direct investment due to uncertainty. Consequently, this study established institutional theories as a theoretical framework. Among the reasons for the choice of the theory are assumptions that 
effective institutions raise benefits and reduce the cost of the transaction of economic activities, induce incentives that shape economic growth and development, and lastly, influence per work output and levels of income.

Following the theoretical postulation and the findings of (Buchanan et al., 2012, p. 84) on "determinants of FDI's inflow", functional model of this study described in equation 1 as:

$$
F D I=f(I N S T)
$$

Where FDI, denote foreign direct investment and INST, is institutional quality. Equation 1 shows that institutional quality is a function of foreign direct investment inflows. Empirically, Samimi, Rezanejad \& Ariani (2010), evaluate the impact of good governance on foreign direct investment in 16 countries in the Middle East and North Africa (MENA) and found that political stability and control of corruption has a positive impact on foreign direct investment inflow. Buchanan et al. (2012), investigates foreign direct investment and institutional quality using panel techniques and established a positive and significant relationship between institutional quality and foreign direct investment. Buchanan et al. (2012) examine 164 countries and the empirical result obtain shows that institutional quality has a positive and significant effect on foreign direct investment. Another review by Bissoon (2012) on a study of 45 less developed countries in the African, Asian, and Latin American reveals that the institutional quality influences inflows of foreign direct investment. Similarly, Jilenga \& Helian (2017) employed the Generalized Method of moments and obtained a positive relationship between institutional quality and foreign direct investment in Sub-Sahara Africa. Also, Hayat (2019) used the same method in 104 countries and the estimation disclosed that institutional quality influences foreign direct investment.

At disaggregated institutional indicators, Ajide, Adeniyi \& Raheem (2014) adopted a panel estimation method in Sub-Sahara Africa and the result indicates that control of corruption, political stability, and government effectiveness influence foreign direct investment. Likewise, Peres, Ameer \& Helian (2018) observed that institutional quality by the sum of control of corruption and rule of law significantly impact on foreign direct investment in developing countries.

Furthermore, in Nigeria, Esew \& Yaroson (2014) employ the Vector Error Correction Model (VECM) and uncovered that political stability and corruption are determinants of foreign direct investment. Akpo \& Hassan (2015) applied the Autoregressive Distributive Lag model (ARDL) and concludes that institutional quality is a determinant of foreign direct investment in Nigeria. Brown \& Ibekwe (2018) took on the Granger causality test and found that political stability has a unilateral predictive effect on foreign direct investment inflows in the Nigerian economy. Omodero (2019) used the Ordinary Least Square Method (OLS) and proved that corruption has a significant and positive effect on foreign direct investment. Similarly, Zangina \& Hassan (2020) employed Nonlinear Autoregressive Distributive Lag (NARDL). The findings confirm that corruption influences foreign direct investment inflow and corruption control has asymmetric effects on foreign direct investment inflow to Nigeria.

\section{Methodology}

Here the procedure used to obtain data and the method of analysis is specified. This study utilizes secondary data. Secondary data is already available data collected by someone other than the researcher. The choice was motivated by the availability of data on the variables employed and is very simple to use. The data employed covered the period of 1999 Q1 - 2019 Q4, sourced from the World Bank development indicators report on Nigeria (2019) and the World Governance indicators (2019). The variables examined are Foreign direct investment, 
aggregate institutional qualities measures as the sum of institutional quality indicators (control of corruption, political stability, and absence of violence, regulatory quality, rule of law, government effectiveness and voice and accountability), employment, market capitalization and access to electricity, all were in percentage. The method of analysis adopted is a Nonlinear Autoregressive Distributive Lag (NARDL) model. The nonlinear Autoregressive distributive lag (NARDL), allow asymmetric long-run and short-run effect estimation, irrespective level of stationarity it can be applied except I (2), and a hidden cointegration easily detected by Nonlinear Autoregressive Distributive Lag, for example, a positive shock of institutional quality may have a larger impact in the short-run while a negative shock has a larger impact in the long-run.

Following the theoretical model in equation 1, institutional quality and control variables like employment, market capitalization, and access to electricity identify as determinants of foreign direct investment. Thus, the model specification adopted is presented:

$$
F D I=F(I N S T A G, E M P, M K L, E T R)
$$

Where: FDI denotes foreign direct investment, INSTAG is aggregate institutional quality - summation of all the institution's index; control of corruption, rule of law, government effectiveness, regulatory quality, political stability and absence of violence, voice and accountability. EMP is the employment rate - the percentage of those that are actively involved in the workforce. MKL is a market capitalization - the traded value of companies listed in the stock market. And ETR represents access to electricity - the percentage of the population that has access to national electricity including organizations, communities, and multinational companies. Equation 2 represents a functional relationship between the explanatory variables and the explained variable. To estimate a linear relationship equation 3 will be considered. Where $\beta$ 's are the parameters estimated, INSTAG, EMP, MKL, ETR are regressors coefficients, $\mu$ is error term or stochastic, and $t=1,2,3 \ldots$

$$
F D I t=\alpha+\beta_{1} I N S T A G_{t}+\beta_{2} E M P_{t}+\beta_{3} M K L_{t}+\beta_{4} E T R_{t}+\mu_{t}
$$

To achieve the objective of this study, a recent Nonlinear Autoregressive Distributive lag model developed by Shin, Yu, \& Greenwood-Nimmo (2014) as an advanced of the conventional Autoregressive Distributive Lag model was adopted (Pesaran, Shin \& Smith, 2001). The method was used to validate the work of Kahneman \& Tversky (1979) and Shiller (1993). They assumed that many studies find an insignificant relationship between economic variables due to assuming a linear relationship.

The Nonlinear Autoregressive Distributive Lag model specified as:

$$
\begin{aligned}
& F D I t=\alpha+\beta_{1}{ }^{+} I N S T A G_{t L}+\beta_{2}{ }^{-} I N S T A G_{t L}+\beta_{3}{ }^{+} E M P_{t L}+\beta_{4} E M P_{t L}+\beta_{5}{ }^{+} M K L_{t L}+\beta_{6} M P L_{t L}+ \\
& \beta 7^{+} E R_{t L}+\beta_{8} E T R_{t L}+\mu_{t}
\end{aligned}
$$

Equation 4 demonstrates the long-run model for estimating Nonlinear Autoregressive Distributive Lag. The model has two components. Partial sum of positive and negative (+ -) change in independent variables. Where INSTAGtL is the long-run aggregate institution variable, EMPtL is the long-run employment rate variable, MKLtL indicates long-run market capitalization variable, ETRtL implies long-run access to electricity, L represents long-run symbolic, $\beta+$, and $\beta$ - are the long-run parameters and respective coefficients. Besides the shortrun estimation describes in equation 5 . 


$$
\begin{gathered}
F D I t=\alpha+\beta_{1}{ }^{+} I N S T A G_{t S}+ \\
\beta_{2}{ }^{-I N S T A G_{t S}}+\beta_{3}{ }^{+} E M P_{t S}+\beta_{4} E M P_{t S}+\beta_{5}{ }^{+} M K L_{t S}+\beta_{6} M K L_{t S}+ \\
\beta_{7^{+} E T R_{t S}+\beta_{8} E T R_{t S}+E C M_{t-1}}
\end{gathered}
$$

Where INSTAGtS illustrates the short-run aggregate institution variable, EMPtS depicts the short-run employment rate variable, MKLtS suggests short-run market capitalization variable, ETRtS signifies short-run access to electricity, and $\mathrm{S}$ is short-run denotation. The essence of equation 5 is to compare the short-run and long-run asymmetric effect of aggregate institutional quality to determine which of the partial sum has much impact on the dependent variable in Nigeria. The error correction mechanism demonstrates the shortrun speed of adjustment to ascertain equilibrium in the long-run. It has two conditions which must be satisfied. Negative and statistically significant.

\section{Results and discussion Descriptive Statistics}

The summary of the descriptive statistics of the variables utilized in the estimation of this study is shown in Table 1. Descriptive statistics present the data in a meaningful way for easy interpretation, for example, it shows the distribution, deviation from the mean, the spread of data, visualization of raw data, etc.

Table 1. Descriptive Statistics

\begin{tabular}{llllll}
\hline & FDI & INSTAG & EMP & MKL & ETR \\
\hline Mean & 1.612160 & -6.706914 & 52.63858 & 10.72994 & 50.93173 \\
Medium & 1.677500 & -6.770000 & 52.84000 & 10.57000 & 50.35500 \\
Std. Dev. & 0.661159 & 0.387683 & 0.414473 & 5.388148 & 4.583879 \\
Skewness & -0.110978 & -0.160382 & -1.123940 & 1.227540 & -0.123696 \\
Kurtosis & 2.087337 & 2.357635 & 2.687290 & 5.600663 & 1.893204 \\
Jarque-Bera & 2.977488 & 1.739889 & 17.38377 & 43.16916 & 4.340923 \\
Probability & 0.225656 & 0.418975 & 0.000168 & 0.000000 & 0.114125 \\
Observation & 81 & 81 & 81 & 81 & 81 \\
\hline
\end{tabular}

Source: Authors' computation (2020)

Table 1 reveals that the mean values and deviations from the mean scores for FDI, INSTAG, EMP, MKL, and ETR within the sample period are 1.612 (0.661), -6.707 (0.388), 54.639 (0.414), 10.730 (5.388) and 50.932 (4.584) respectively. The MKL reported the highest deviation. Likewise, the Skewness $-0.111,-0.160,1.352,-1.124$, and -0.124 respectively, symbolize that while the majority of the data points lay on the left-hand side of the normal curve except that for MKL which spread from the right-hand side of the normal curve. The Jarque-Bera test for normality shows that EMP, MKL, and ETR are normally distributed leaving out FDI and INSTAG.

\section{Empirical Results}

The strategy for measuring the empirical model of this study involves first, experimenting, or testing the individual properties of the time-series data towards establishing a suitable and adequate technique to be adopted in the estimation. Accordingly, the Augmented 
Dickey-Fuller (ADF) and Phillips-Perron (PP) for unit root tests were performed and the outcomes related in Table 2.

Table 2. Test for Unit Root Results

\begin{tabular}{lllll}
\hline & \multicolumn{2}{c}{ Level } & \multicolumn{2}{c}{ First Difference } \\
Series & ADF & PP & ADF \\
\hline FDI & -0.322 & -0.808 & -2.235 & $-4.497^{* * *}$ \\
INSTAG & $-3.126^{* *}$ & $-2.586^{*}$ & $-3.284^{* *}$ & $-4.051^{* * *}$ \\
EMP & -1.298 & -0.252 & $-2.499^{*}$ & $-2.637^{*}$ \\
MKL & $-2.582^{*}$ & -2.024 & -2.189 & $-4.110^{* * *}$ \\
ETR & -1.370 & $-4.449^{* * *}$ & -1.027 & $-4.5801^{* * *}$ \\
\hline
\end{tabular}

*** significant at $1 \%$ level, $* *$ significant $5 \%$ level and $*$ significant $10 \%$ level

Source: Authors' computation (2020)

The null hypothesis of the tests has it that a particular series has a unit root. Hence, Table 2 shows that while FDI and EMP achieved stationary after first difference, EMP in both the ADF and PP, FDI only in PP tests. Similarly, INSTAG stationary at a level in both ADF and PP. MKL and ETR stationary at a level in ADF and PP. The results of the unit root tests signify the variables have a mixed level of integration. This has to validate the use of the intended NARDL model. Therefore, the Nonlinear Autoregressive Distributive Lag (ARDL) Bounds test was used to establish whether a long-run relationship exists among the variables. The result of the NARDL Bounds test, shown in Table 3.

Table 3. Result of the Bounds Test

\begin{tabular}{lllll}
\hline Test Statistics & Value & Significance & $\mathrm{I}(0)$ & $\mathrm{I}(1)$ \\
\hline F-statistics & 4.755 & $10 \%$ & 1.85 & 2.85 \\
$\mathrm{~K}$ & 8 & $5 \%$ & 2.11 & 3.15 \\
& & $1 \%$ & 2.62 & 3.77 \\
\hline
\end{tabular}

Source: Authors' computation (2020)

Note: The automatic lag selection was used to determine the maximum lag length

Given the F-statistics value (4.755) greater than the upper boundary at $10 \%, 5 \%$ and $1 \%$ level of significance respectively, the variables have been said to have a long-run relationship, signing that the independent variables have a long-run relationship with the dependent variable. Then, the estimation of the NARDL model was considered appropriate to determine the short-run and long-run asymmetric relationship between FDI and the explanatory variables in Nigeria. Table 4 presented both short-run and long-run estimates.

Table 4. NARDL Results. Dependent variable (FDI)

\begin{tabular}{lll}
\hline Variables & Coefficients & t-statistics \\
\hline INSTAG_POS & 0.852 & $2.338 * *$ \\
INSTAG_NEG & -2.653 & $-6.381 * * *$ \\
EMP_POS & 24.939 & 4.590 \\
EMP_NEG & 0.004 & 0.012 \\
MKL_POS & -0.167 & $-3.735 * * *$ \\
MKL_NEG & 0.335 & $4.023 * * *$ \\
ETR_POS & -0.384 & $-7.930 * * *$
\end{tabular}




\begin{tabular}{lll}
\hline ETR_NEG & 0.005 & 0.073 \\
& Short-Run & \\
INSTAG_POS & 1.606 & $10.551^{* * *}$ \\
INSTAG_NEGs & -0.785 & $-6.363^{* * *}$ \\
EMP_POS & -0.513 & -0.516 \\
MKL_POS $_{\mathrm{S}}$ & 0.110 & $6.311^{* * *}$ \\
MKL_NEG $_{\mathrm{S}}$ & -0.087 & $-4.834^{* * *}$ \\
ETR_POS & 0.128 & $5.810^{* * *}$ \\
ETR_NEG & 0.215 & $7.135^{* * *}$ \\
ECM & -0.300 & $-7.689^{*}-1 * *$ \\
DW Stat. $=2.228$ & $\mathrm{R}^{2}=0.919$ & Adjusted $\mathrm{R}^{2}=0.867$ \\
\hline
\end{tabular}

Source: Authors' computation (2020)

Having obtained both long-run and short-run asymmetry estimated models in (4) and (5). Dynamics asymmetric results for both short-run and long-run are given in Table 4 . In the long-run, coefficients of aggregate institutional quality, significant relationship is confirm for both positive (INSTAG+L), and negative (INSTAG-L). Especially, the effect of the positive component of aggregate institutional quality on foreign direct investment is statistically significant, with a 1 percent increase of institutional quality, leading in a 0.85 percent increase in foreign direct investment in Nigeria. This corroborated with the above-cited literature, particulary with Samimi, Rezanejad \& Ariani (2010), Buchanan et al, (2012) and Jilenga \& Helian (2017). They found that institutional quality has a positive effect on FDI. Correspondingly, the effect of the negative component of aggregate institutional quality on foreign direct investment is statistically significant and bigger in magnitude, with a percentage decrease of aggregate institutional quality, resulting in an average of $2.65 \%$ decrease in FDI in Nigeria. These findings revealed that the long-run negative component of aggregate institutional quality impact is larger than the positive component by 1.8. Nonetheless, in the long-run, employment $(\mathrm{EMP}+\mathrm{L})$ or size of the working force positive component has a positive and statistical significance effect on FDI, a percentage increase in the working force leading to an average of $24.94 \%$ improvement in FDI while the negative component (EMP -L) expressed a positive sign but statistical insignificance. Meaning a percentage decrease in the working force will bring about a $0.004 \%$ gain in FDI. However, the market share measured using market capitalization, both positive and negative components (MKL+ - L) show a significant effect on FDI. Specifically, a 1 percent increase in the positive component of the market share (MKL+ L) leading to an average of $0.17 \%$ reduction in FDI. Similarly, a 1 percent decrease in the negative component of the market share (MKL- L) will result in a $0.34 \%$ increase in FDI. This finding complies with Dunning (1993) and Balasubramanyam et al. (1996). Furthermore, access to electricity positive components has a depreciating effect on the FDI and statistical significance while the negative component prevailed an insignificant appreciating effect on FDI. Particularly, the positive component of access to electricity on FDI (ETR+L), with a percentage increase in access to electricity yielding a depreciation of 0.38 percentage on FDI. The negative component (ETR-L) on FDI reveals an appreciation of $0.005 \%$ statistical insignificance.

In the short-run, a significant relationship was obtained for both positive (INSTAG+S) and negative (INSTAG-S) coefficients of aggregate institutional quality. Specifically, the effect of the positive components of aggregate institutional quality on foreign direct investment 
is statistically significant, with a $1 \%$ increase in the aggregate institutional quality resulting in an average of $1.61 \%$ increase in foreign direct investment. This is corresponding with Buchanan et al. (2012), Bissoon (2012), Akpo \& Hassan (2015) and Jilenga \& Helian (2017). Similarly, the negative component of aggregate institutional quality on foreign direct is statistically significant, a $1 \%$ decrease in institutional quality leading to an average of $0.79 \%$ decline in FDI in Nigeria is observed. Therefore, the findings revealed that the short-run positive component of aggregate institutional quality impact is larger than the negative component by $0.82 \%$. Furthermore, both the positive and negative changes in the market share (MKL+ - S) have a statistically significant effect on FDI in the short-run. That is the positive $(\mathrm{MKL}+\mathrm{S})$ component on FDI, with a percentage increase in MKL, FDI appreciated by 0.11 percentage. Similarly, the negative (MKL-S) component on FDI, with a percentage decrease in MKL, FDI depreciated by 0.09 percentage. Also, both positive and negative components of access to electricity (ETR+ $-\mathrm{S}$ ) effect on FDI are statistically significant. Implying that the positive component of access to electricity on FDI $(E T R+S)$, a percentage increase in access to electricity yielding appreciation of 0.13 percentage on FDI. In the same manner, the negative access to electricity component on FDI (ETR-S), $1 \%$ reduction in the access to electricity will result in an average of $0.22 \%$ increase in FDI.

The finding also reveals the speed of adjustment (ECMt-1) has the required sign negative and is statistically significant. Meaning, a short-run shock will be adjusted to equilibrium in the long-run with an average speed of $30 \%$ quarterly. The coefficient of determination $\left(\mathrm{R}^{2}\right)$ shows that the variables employed accounted for $92 \%$ variation in the response variable and the remaining $8 \%$ have not been captured. This implied that the model is a good fit. Durbin Watson statistics reveal the absence of autocorrelation since the estimated value approximately is not more than 2 .

After ascertains long-run and short-run NARDL results, there is need to test for the assumptions of the technique used (Normal distribution of error term, serial correlation, and heteroscedasticity) as well the stability of the estimated model to determine whether the method of analysis adopted passed the classical OLS assumption and stability test or not, established in Table 5 and 6:

\section{Table 5. Diagnostic tests}

\begin{tabular}{lll}
\hline Tests & Statistics & Prob. \\
\hline Normal distribution & Jarque-Bera & 0.363 \\
Serial correlation & Breusch-Godfrey & 0.105 \\
Heteroscedasticity & Breusch-Pagan-Godfrey & 0.936 \\
\hline
\end{tabular}

Source: Authors' computation (2020)

The classical assumption of the OLS method employed given the probability values in Table 5 shows that the error term is normally distributed with zero mean and constant variance, homoscedastic, and not serial correlated. Thus, it concluded that the model passed the key assumptions test, the findings and policy implications of the paper stand to be implemented by any relevant and concerned organizations.

Table 6. Stability tests

\begin{tabular}{lll}
\hline Tests & Statistics & Prob. \\
\hline Ramsey RESET & F-statistics & 0.466 \\
CUSUM and CUSUMQ & Stable & 0.05
\end{tabular}

Source: Authors' computation (2020) 
Table 6 shows results for Ramsey RESET and CUSUM and CUSUMQ. Ramsey RESET presented with a probability value greater than $5 \%$. This implied that the model is wellspecified. CUSUM and CUSUMQ are stable because the probability value is within the required region of 5\% (0.05). Based on these outcomes, the policy recommendation from this study is valid.

\section{Conclusion and recommendations}

The study examines the asymmetric relationship between aggregate institutional quality and foreign direct investment in Nigeria. The NARDL model was adopted on quarterly timeseries data from 1999 Q1 - 2019 Q4, a deviation from the traditional annual time-series data employed by previous literature. The bounds test obtains revealed that long-run co-integrating relationship exist between the institutional quality and foreign direct investment in Nigeria. The NARDL result shows that in the short-run and long-run the positive components of the aggregate institutional quality have an appreciating effect on foreign direct investment and statistical significance. Similarly, the negative components of the aggregate institutional quality have a decline effect on foreign direct investment and statistically significant in both the short-run and long-run.

It was also discovered that the positive component of the aggregate institutional quality in the short-run has a larger effect on foreign direct investment than the negative component. Likewise, in the long-run, the negative component of the aggregate institutional quality has a larger effect on foreign direct investment than the positive component. Generally, the negative component of the aggregate institutional quality has a substantial effect on foreign direct investment than the positive component. The aggregate institutional quality and control variables exploited in the model are determinants of foreign direct investment in Nigeria proofed by the coefficient of determination (92\%). The short-run partial shock caused by aggregate institutional quality and control variables can converge to equilibrium in the longrun at an approximate speed of 30\% quarterly. This study established that efficient institutional quality will positively and significantly attract investors and amplify economic growth all things being equal.

The study recommends, that the relevance of aggregate institutional quality attracts FDI inflows, hence, the government should establish or strengthen the quality of institutional indicators and legal framework to secure confidence in the system to motivate FDI inflow. This is because the aggregate institutional quality is found to have an asymmetric effect on the FDI both in the short-run and long-run in Nigeria.

This study is among the first to used time-series data to measure the effect of aggregate institutional quality on foreign direct investment in Nigeria, was constrained with a lack of available studies to compare its findings with. Another weakness is the inability of the researchers to estimate the symmetric effect along to carry out a comparative validation of the method of analysis adopted. Therefore, further studies should investigate both the symmetric and asymmetric effects of the aggregate institutional quality on foreign direct investment in Nigeria.

\section{Acknowledgments}

We thank the World Bank and World governance indicators for regular publication of data that gave a boost to this study. The authors thank the reviewers and editors of Journal Economics and Law for their precious and valuable contribution. 


\section{References}

Ajide, K., Adeniyi, O., \& Raheem, I. (2014). Does Governance Impact on the Foreign Direct Investment Growth Nexus in Sub-Saharan Africa? Zagreb International Review of Economics \& Business, 17(2), 71-81

Akpo, E. S., \& Hassan, S. (2015). Institutional Quality Matter: An Empirical Investigation of Foreign Direct Investment in Nigeria. e-Journal of the Social Science Researches, $3,60-73$

Ali, F. A., Fiess, N., \& MacDonald, R. (2010). Do institutions matter for foreign direct investment? Open Economies Review, 21(2), 201-219. https://doi.org/10.1007/s11079-010-9170-4

Alfaro, L., Chanda, A., Kalemli-Ozcan, S., \& Sayek, S. (2004). FDI and Economic Growth: The Role of Local Financial Markets. Journal of International Economics, 64, 89112. https://doi.org/10.1016/S0022-1996(03)00081-3

Azman-Saini, W. N. W., Law, S. H., \& Ahmad, A. H. (2010). FDI and economic growth: New evidence on the role of financial markets. Economics letters, 107(2), 211-213. https://doi.org/10.1016/j.econlet.2010.01.027

Balasubramanyam, V. N., Salisu, M., \& Sapsford, D. (1996). Foreign Direct Investment and Growth in EP and IS Countries. The Economic Journal, 106 (434), 92-105. https://doi.org/10.2307/2234933

Bengoa, M., \& Sanchez-Robles, B. (2003). Foreign Direct Investment, Economic Freedom, and Growth: New Evidence from Latin America. European Journal of Political Economy, 19(3), 529- 545. https://doi.org/10.1016/S0176-2680(03)00011-9

Bissoon, O. (2012). Can better institutions attract more foreign direct investment? Evidence from developing countries. International Research, Journal of Finance and Economics, 82, 142-158.

Blomstrom, M., Lipsey, R., \& Zejan, M. (1994). What Explains Developing Country Growth? Convergence and Productivity: Gross-National Studies and Historical Evidence. Oxford: Oxford University Press.

Borensztein, E. R., De Gregorio, J., \& Lee, J. (1998). How Does Foreign Direct Investment Affect Economic Growth? Journal of International Economics, 45 (1), 115-135. https://doi.org/10.1016/S0022-1996(97)00033-0

Buchanan, B. G., Le, Q. V., \& Rishi, M. (2012). Foreign direct investment and institutional quality: Some empirical evidence. International Review of financial analysis, 21, 8189. https://doi.org/10.1016/j.irfa.2011.10.001

Busse, M., \& Hefeker, C. (2007). Political risk, institutions and foreign direct investment. European Journal of Political Economy, 23(2), 397-415. https://doi.org/10.1016/j.ejpoleco.2006.02.003

Daude, C., \& Stein, E. (2007). The quality of institutions and foreign direct investment. Economics \& Politics, 19(3), 317-344. https://doi.org/10.1111/j.1468$\underline{0343.2007 .00318 . x}$ 
Brown, E. D., \& Ibekwe, E. E. (2018). Effect of Institutional Factors on Foreign Direct Investment in Nigeria. The Economics and Finance Letters, 5(1), 12-27.. https://doi.org/10.18488/journal.29.2018.51.12.27

Dunning, J. H. (1993). Multinational Enterprises and the Global Economy. Addison Wesley: New York.

Esew, N. G., \& Yaroson, E. (2014). Institutional Quality and Foreign Direct Investment (FDI) In Nigeria: A Prognosis. Journal Of Humanities And Social Science (IOSRJHSS) 19(6), 37-45.

Fagbemi, F., \& Bello, K. M. (2019). Foreign Direct Investment-Growth Linkage in SubSaharan Africa: Is Governance a Mediating Factor?. International Journal of Business, 6(2), 111-129.

Gönel, F., \& Aksoy, T. (2016). Revisiting FDI-led growth hypothesis: the role of sector characteristics. The Journal of International Trade \& Economic Development, 25(8), 1144-1166. https://doi.org/10.1080/09638199.2016.1195431

Hayat, A. (2019). Foreign direct investments, institutional quality, and economic growth. The Journal of International Trade \& Economic Development, 28(5), 561-579. Retrieved from https://mpra.ub.uni-muenchen.de/91213/

Havranek, T., \& Irsova, Z. (2011). Estimating Vertical Spillovers from FDI: Why Results Vary and What the True Effect Is? Journal of International Economics, 85(2), 234244. https://doi.org/10.1016/j.jinteco.2011.07.004

Hermes, N., \& Lensink, R. (2003). Foreign Direct Investment, Financial Development, and Economic Growth. Journal of Development Studies, 40(1), 142-163. https://doi.org/10.1080/00220380412331293707

Javorcik, B. S. (2004). Does Foreign Direct Investment Increase the Productivity of Domestic Firms? In Search of Spillovers through Backward Linkages. The American Economic Review, 94(3), 605-627. https://doi.org/10.1257/0002828041464605

Jilenga, M. T., \& Helian, X. (2017). Foreign direct investment and economic growth in SubSaharan Africa: The role of institutions. Turkish Economic Review, 4(4), 378-387.

Kahneman, D., \& Tversky, A. (1979). Prospect theory: An analysis of decision under risk. Econometrica, 47(2), 263-292.

North, D. C. (1991). Institutions. Journal of economic perspectives, 5(1), 97-112.

Omodero, C. O. (2019). Effect of corruption on foreign direct investment inflows in Nigeria. Studia Universitatis ,, Vasile Goldis” Arad-Economics Series, 29(2), 54-66. https://doi.org/10.2478/sues-2019-0008

Oke, B. O., Ezike, J. E., \& Ojogbo, S. O. (2012). Locational Determinants of Foreign Direct Investment in Nigeria. International Business Research 5(4), 103-111. https://doi.org/10.5539/ibr.v5n4p103

Peres, M., Ameer, W., \& Helian, X. (2018). The impact of institutional quality on foreign direct investment inflows: Evidence for developed and developing countries.

Economic Research, 31(1), 626 - 644. https://doi.org/10.1080/1331677X.2018.1438906 
Pesaran, M. H., Shin, Y., \& Smith, R. J. (2001). Bounds testing approaches to the analysis of level relationships. Journal of applied econometrics, 16(3), 289-326. https://doi.org/10.1002/jae.616

Samimi, A. J., Rezanejad, Z., \& Ariani, F. (2010). Growth and FDI in OIC Countries. Australian Journal of Basic and Applied Sciences, 4(10), 4883-4885.

Shiller, R. J. (1993). Macro markets: Creating institutions for managing society's largest economic risks. Oxford: Clarendon Press.

Shin, Y., Yu, B., \& Greenwood-Nimmo, M. (2014). Modelling asymmetric cointegration and dynamic multipliers in a nonlinear ARDL framework. Springer, New York, NY.

World Bank (2019). World development indicators report on Nigeria. Washington DC: Author. Retrieved from http://documents1.worldbank.org/curated/en/816281518818814423/pdf/2019-WDR$\underline{\text { Report.pdf }}$

World governance indicators (2020). Governance indicators. Washington DC: Author Retrieved from https://datacatalog.worldbank.org/dataset/worldwide-governanceindicators

Zangina, S., \& Hassan, S. (2020). Corruption and FDI inflow to Nigeria. A nonlinear ARDL approach. Journal of Financial crime, 27(2), 635 - 650. https://doi.org/10.1108/JFC$\underline{\text { 09-2019-0116 }}$ 


\title{
THE LESSONS LEARNED FROM THOMAS COOK FAILURE. IS IT BREXIT?
}

\section{DOAA SALMAN ${ }^{1}$ \\ DINA SEIAM ${ }^{2}$}

\begin{abstract}
The aim of this research paper is to discuss market failure of Thomas Cook and analyse the reasons behind the market failure of Thomas Cook Group and how outdated technology, having high debts, and did Brexit lead to its collapse. Further on analysis of the reasons for failure supported by literature review across different economic schools has been elaborated. The paper provides clarification to the characteristics of the airlines and their entry barriers taking into consideration the tour operator. Further, it is described how Thomas Cook collapse affected Africa and Europe. Lastly, the conclusion is about the losses occurred in Thomas Cook Company, how other firms can avoid failure and the direct negative impact of the BREXIT on the company.
\end{abstract}

Keywords: debt problems, bankruptcy, tourism

JEL Codes: F34, G33, Z32

\section{Introduction}

In any event market can be understood as a place where products are bought and sold at wholesale or retail prices. However, in economics the word "market" refers not to a specific place as such, but to a market for a commodities. It is a system in which buyers and sellers come into direct or indirect contact with each other for the sale and purchase of goods.

Every market always tries to serve a sufficient number of customers to maintain high profits with fewer costs, besides every firm tries to avoid any market failure to occur by planning for the future years and concern to have less load of debts.

Thomas Cook, one of the most famous tour operators on earth, offered low-cost vacation packages to dozens of destinations around the world, making it a popular option to travellers looking for an affordable getaway. Thomas Cook Group Plc had been involved in the fields of tourism and travel. The company owned, operated, and maintained travel agents, tour operators, and agencies for car rental, and owned its own fleet of aircraft, cruise ships, and resorts. Thomas Cook, was the British innovator and founder of the worldwide tourism business Thomas Cook and Son. It can be said that Cook had invented modern tourism and was known as the father of tourism package tours. Also, there is a lot of history, they come with, and besides the business had 178 years of history (Leadbeater, 2019).

The research is divided into different sections, starting with a literature review that discusses two points first is the market type of the airline industry and tour business and second is the market failure and reasons that caused it it. Followed by the characteristics of the airline industry, then the barriers of entry in both airlines and tour business. Next, a indepth analysis of Thomas Cook's collapse stressing on the debt and lack of updating with the new technology has been made. Later, a description on how Europe and Africa were affected by the collapse is

\footnotetext{
${ }^{1}$ October University for Modern Sciences and Arts, Cairo, Egypt, dsalman@msa.eun.eg ORCID iDhttps://orcid.org/0000-0001-5050-6104

${ }^{2}$ October University for Modern Sciences and Arts, Cairo, Egypt, dinaseiam@gmail.com ORCID IDhttps://orcid.org/0000-0002-0204-6753
}

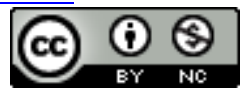

This work is licensed under a Creative Commons Attribution-NonCommercial 4.0 International License 
represented. Eventually, the research ends with a conclusion that shows the losses of Thomas Cook and proposes policies to overcome the collapse.

\section{Literature Review}

\subsection{Market Category}

Travel agencies and airlines are known to be a profitable oligopoly industry and a form of imperfect competition because it is a kind industry that has a few major companies and a large number of purchasers. Every seller has a large market share. There are a few large firms in the oligopoly, which means that every player has its own importance and can affect the market price of the commodity, in addition there are many purchasers on the market. The number is increasing in a way that the market price cannot be influenced by any individual buyer. The entry of new companies is limited by numerous barriers, the obstacles are almost like those of monopoly. It is very difficult but not impossible for the new business to enter the market. In addition, a cartel can be created to prevent the competitiveness. Cartel is a negotiated arrangement between the companies aimed at reducing market competition. In oligopoly market prices can be regulated, each rival company responds instantly to the changed price, as a result of which the price stays rigid on the market (Rubin \& Joy, 2005).

The shape of the demand curve is indeterminate in the oligopoly, because if one company reduces the price, we cannot guarantee whether the company will sell more. Their current rigidity in prices and the cartels. There are two types of collusive and non-collusive oligopolies. The first type is collusive, it is a form of business in which there are few companies on the business and all agreed to avoid competition through structured agreement. They collude in forming a cartel and in setting production quotas and market price for themselves. Often the cartel recognizes a leading firm in the industry as a price leader. Cartel participants accept the price as set by the price leader. The second type is non-collusive, it is the form of a market in which there are few companies on the market and each company sets its price and production and all companies are separate from the rival companies. Each company strives to increase its market share through competition. Competition preferred as a method of raising profit by a few firms on the market.

\subsection{Market failure}

The failure of the market refers to the inefficient distribution of free market goods and services. The prices of goods and services in a typical free market are determined by supply and demand strengths and every change in one force results in price shifts and an appropriate change in the other. The changes have resulted in a price balance. In other words, market failure happens when market distortions create a state of unbalance. It happens when the supplied amount of goods or services does not equate to the required amount of goods or services. Many inequalities affecting the free market may include monopoly power, price controls, wage minimum requirements and regulations of the government (Corporate Finance Institute, 2015).

There are seven different reasons that causes of market failure. Firstly, private markets are commonly known as being incapable of producing public goods. Secondly, where externalities or spill overs occur between various economic activities, which result in a difference between social costs and benefits as well as private costs and benefits. Such issues are industrial pollution as markets may fail to deliver efficient results because market rates do not represent the true social costs and benefits involved. Thirdly, if markets are monopoly or oligopoly rather than competitive, there would be markets failure. Fourthly, where either purchasers or sellers have insufficient information or when the information that is available is asymmetrically applied to participants in the market, markets that collapse. Fifthly, incomplete markets could lead to market failure because markets cannot supply all goods and services because demand is insufficient to cover the cost of supply. A sixth and related type of market 
failure is induced by incomplete markets implying that complementary markets are absent. Complementary between markets is said to occur where operation in one market depends on the presence of other relevant markets. Finally, market failure is also claimed to occur in the macro-economies of industrial societies in the context of a business loop Periodic economic downturns resulting in unemployment and decline in income, whereas economic upturns may create inflationary episodes. This form of macro-economic uncertainty is generally faced with policy interference in the umbrella of macroeconomic measures intended to flatten the market cycle. Usually, these macro-economic strategies aim to boost economic growth during recessionary times and to minimize this development during boom cycles. (Dollery \& Wallis, 1997).

\section{Characteristics of airline industries}

As we have mentioned beforehand that both airline industries and travel agencies are player on a oligopoly market. They produce an homogenous product but have price discrimination, where businesses charges are at a different rates to consumer groups for the same commodity, depending on their willingness to pay. There are three different types of price discrimination, first-degree, second-degree and third-degree. According to Stavins (1996), airlines price differentiates in two ways: first, by providing customers a variety of packs, or variations of fares and ticket restrictions; and second, by reducing the number of discounted seats on each trip. The first type of price discrimination is known as second degree or price discrimination based on self-selection. Consumers select their favourite product version based on their ability to pay for particular good attributes (e.g. time, ease, flexibility). The second form is a case in which carriers use a rationing system and limit the cheaper good's supply. For this analysis both of these are combined.

However, Hazledine (2010) claims that airline industries and travel agencies follow first-degree price discrimination. First-degree price discrimination means the practice of charging each customer his/her reservation price (a maximum charge that a consumer is willing to pay for a good). In the case of airlines, there are different flight classes like economy, premium economy, business, and first-class. Each of these categories charged differently.

Airlines distinguish between themselves by occupying various slots in flight schedules and by providing specific networks of routes. For instance, a carrier with a large number of West Coast connections varies from a carrier flying only along the East Coast, even though both sell tickets for the Boston-Miami route. Therefore, such a market is competitive monopolistic. In addition, consumers differ in demand because of their varying price elasticity. Although it is possible to resell airline tickets, it requires high search costs and does not remove limitations such as blackout days or time-of-day limitations (Stavins, 1996).

\section{Barriers and limitation to enter}

\subsection{Airline Industry}

There are several entry barriers for a airline which are fleet costs, fuel, government regulations, competition, and cabin crew. Let's start with the fleet costs, for many beginners in the airline industry, purchasing a fleet of aircraft poses a major barrier to entry. Singleaircraft prices ranged from around $\$ 11$ million for a small Embraer prop plane built for regional operation to over $\$ 320$ million for a Boeing 777 . Nevertheless, this is not a straightforward industry to enter into without a huge amount of capital. Besides several airlines overcome the financial obstacle by purchasing used planes from other airlines to build a fleet. For example, Allegiant Air started off at a larger competitor with a fleet of MD-80s retired from the service.

Next is fuel, along with the other costs of starting an airline, fuel is the greatest entry obstacle for many beginners to the industry. Fuel prices account for up to 50 per cent of the 
expenses of an airline. The fluctuation in fuel prices can make it difficult for a start up to budget accurately without financial strategies which commit far in advance to specific purchases.

Moreover, government regulations, airlines are subject to a wide number of government regulations, and for certain airline businesses, compliance with all of them may be a barrier to entry. Regulatory provisions, including compulsory reimbursement for rejected bookings, a compulsory 30-minute notice of changes in flight status and guidelines on how airlines have to deal with tarmac delays, cost the entire airline industry more than $\$ 1.5$ million annually (Evans, 2019).

Aside from government regulation, new airlines will face a significant entry barrier simply by attempting to get a gate at a major airport. A limited number of major airlines regulate most of the gates at large hub airports, making it difficult for new airlines to gain a foothold in such markets (Evans, 2019).

Lastly the pilots, staffing an airline requires a range of entry-roles to be filled, but the company still wants qualified expertise in the pilot's seat. A report discusses an ongoing pilot shortage, and states that new pilots continue to choose a job in an existing business rather than a more risky start up (Evans, 2019).

\subsection{Tour Business}

Companies seeking to develop themselves as travel agents and tour operators face a range of legal and financial obstacles. Such barriers could reduce the number of companies seeking to enter the market by reducing competition. A business wishing to develop itself as a tour operator providing package holidays must be authorized by ATOL (Air Travel Organizers Licensing). The scheme is intended to ensure that holidaymakers do not risk money and are not left stranded overseas if they fly with a company that they have booked to liquidate. Tour operators applying for a license would have to pay into an insurance program to repay passengers harmed by a tour operator's failure.

Association of Independent Tour Operators (AITO) may be joined by the small independent tour operators. There are around 160 AITO participants, most are owner controlled with a specified aim of offering preference, price, and operation. They usually concentrate on specialty holiday market selling package tours to different regions or areas. Alternatively they can concentrate on a particular style of vacation (safari, adventure, etc.). These businesses must provide quality support, quality guidance or any other aspect of the holiday that can have added benefit or a means of competitive advantage in order to compete with the big operators. AITO members popularity is mirrored in their continued participation in the consumer-voted Travel Awards.

The cost of breaking into the holiday business is a subject of discussion. One leading tour operator estimated that the risk of operating as a tour operator serving 200000 passengers would entail a $£ 6$ million insurance guarantee and $£ 9$ million net assets. In addition, a corporation entering the market might expect the first three years of trading to be loss-making (Economic Investigations, 2015).

Branding is another possible entry obstacle. Customers can be expected to have a preference for a given holiday company. That is not the case in fact. Surveys among holidaymakers show that one of the least important influences influencing tourists purchasing tastes has been the holiday business brand (Economic Investigations, 2015).

\section{Reasons for the failure of Thomas Cook}

Investigating for the reasons will provide insight of the lessons to be learned to avoid similar pitfalls. Thomas Cook has been trapped in the past, despite all his 178-year history. It had been a master of package holidays, using its worldwide name image and financial strength to establish relationships with hundreds of small tour operators, hotels and caterers. Yet, all 
these supply chain alliances have made it very linear, allowing travellers no options or versatility. After rescue talks failed to secure $\$ 250$ million in contingency funds, Thomas Cook fell into liquidation in September in 2019, leaving several thousands who paid the firm for holidays without a return ticket home. There are different reasons for the collapse of the company Brexit, debt, and inability to adapt to a new generation technology and remain competitive.

\section{1. Brexit}

Thomas Cook blamed Brexit's confusion, reporting a £1.5bn loss and stating several offers for his airline had been made. The tour operator said UK tourists missed their summer holidays due to political impasse. The heat wave last summer has lowered consumer appetite for winter sun and, according to Chief Executive Peter Fankhauser, led to the "poor operating climate". Shares in Thomas Cook slumped more than 17 per cent after their results were announced for the six months to March 31 in 2019. More than two-thirds of the pre-tax losses, $£ 1.1 \mathrm{bn}$, were linked to a 2007 reassessment of the company's integration with MyTravel (Kollewe, 2019).

The firm said in a statement that "financial instability in recent months relating to Brexit has resulted in lower demand for summer holidays across the market". After reporting firstquarter losses of $£ 60 \mathrm{~m}$, the tour operator put their in-house airline up for sale in February.

Until then, it has been getting offers for all or part of the company, Mr Fankhauser said. "As we review these bids, we will find all opportunities to maximize shareholder interest and step up our strategic focus", he stated (Stubley, 2019).

\section{2. Debt}

Thomas Cook was in debt of $£ 1.7$ billion, about $\$ 2.1$ billion, which they called "insurmountable" as per Chief Executive Peter Fankhauser. They had been negotiating for $\$ 250$ million in emergency funding when bankruptcy was declared (Sims, 2019). The following figure represents the extreme duration due to the increase net debt, a status that reflect on the decline of the earning per share during the period 2013-2018.

Figure 1. Basic EPS and underlying EPS and net Debt
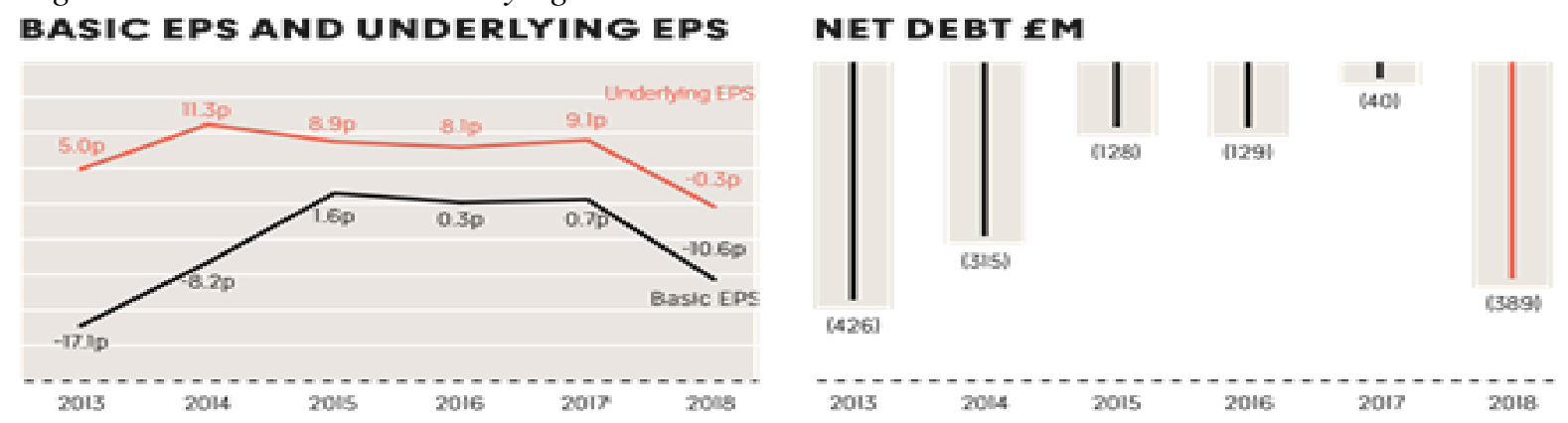

Source: Thomas Cook Group annual report, 2018

From the above figure, we can observe that the profits were on minus in 2007, due to some unwise deals when the company merged with MyTravel Group (a company that in the previous six years had made profits only once) resulting in extreme debt for the group. In 2011, the company failed to clear the $£ 1.1$ billion debt burden that nearly had already destroyed it. Although, the shareholders raised $£ 425$ billion in 2013 , which were insufficient in order to pick up the company from the red line with enormous amounts of money just paid to meet the outstanding debt. Indeed, as of 2011, 1 1.2 billion had been waged in interest alone. And by the end, the accrued debts had been estimated on $£ 1.7$ billion, which meant that they had to sell only three million vacations a year to cover its interest (Hernandez, 2020). 
The situation only worsened in 2016 when there was political unrest in Turkey and an attempted presidential coup, which led to a sharp downturn in tourist visits in the country which was one of Thomas Cook's top customer destinations. And with Brexit raising other concerns such as a severe weakening of the pound that was affecting UK consumers overseas travels, and the unsure atmosphere that was contributing to decline in summer vacation reservations, Thomas Cook ended up facing considerably harsher headwinds, which could not eventually be resolved. In addition, Thomas Cook secured a rescued deal of $£ 900$ million led by his largest Chinese shareholder, Fosun in August 2019, but its banks recent demand to raise additional $£ 200$ million in contingency funding put the deal in doubt. In the next month, the company could not continue with the huge debts that it reached into, which lead to huge negative loss (Hernandez, 2020).

Figure 2. Five-Year Average Operating Profit Margin, in percentage

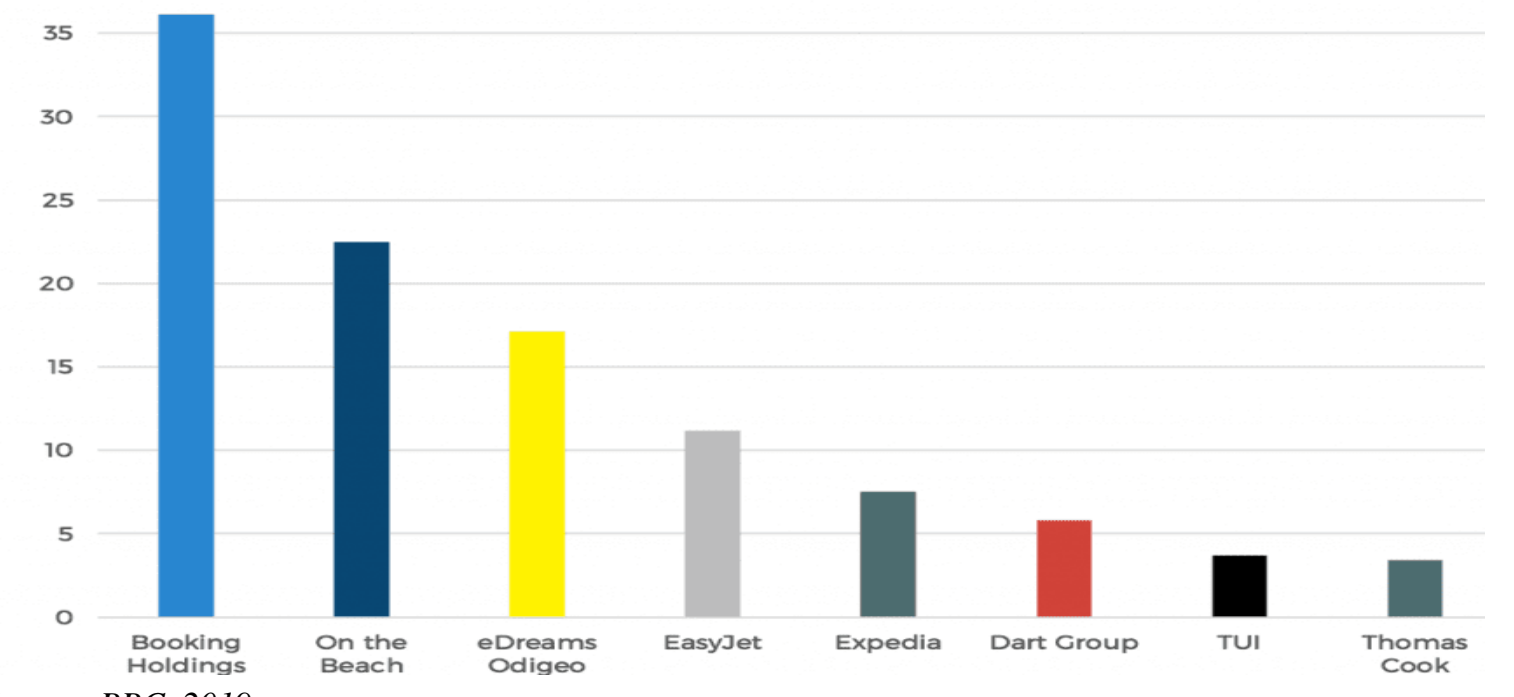

Source: BBC, 2019

\section{3. Lack of update with new technology}

While the travel bookings business has moved online further and further, the Thomas Cook had nor done that, although it signed an Expedia partnership in 2017. It depended on telephone and offices sales (Sims, 2019).

As we see from the above chart Thomas Cook had lowest profir margins among the other travel companies due to the failure to adopt the new generation type of operations like other more flexible traveling companies remaining competitive services, low-cost airlines and travel-related online services. People started booking online and when it comes to developing their packages, customers have much more visibility and flexibility in booking with different airlines. However, in the case of Thomas Cook customers need to run multiple searches to view the same kind of options (Whyte, 2019).

Figure 3. Thomas Cook share price - price in pence (2007-2019) 


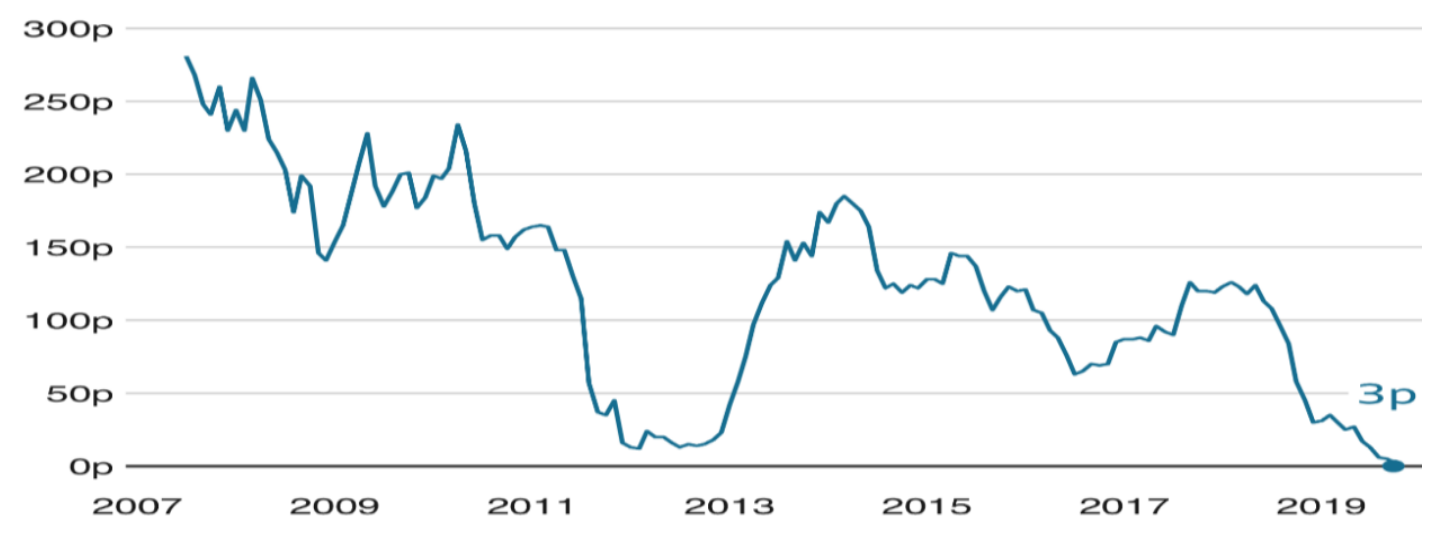

Source: https://www.bbc.com/news/business-49791249

As we see from the Figure 3, the market share price fluctuated throughout the years. In the period between 2011 and 2013 there was a sharp decline in the company's market share that reached to 13.50 pence due to the failure of paying the debt. However, it prive had been raised later in 2013 when Thomas Cook announced the creation of the new Digital Advisory Board to assist management in recognizing "the leading online trends" and raising of money from the shareholders (Whyte, 2019). At the end in 2019, the market share reached a price of 3.50 pence due to the large debts and the high-street market made the company a weak survival candidate, besides the failure was "a matter of deep regret" according to Peter Fankhauser, Thomas Cook Chief Executive Officer (BBC, 2019).

\section{Thomas Cook's loss sounded across Europe and Africa}

Thomas Cook's downfall thrown policymakers across Europe and Africa into disaster contingency mode as they had to help repatriate more than 500,000 displaced visitors and continue to count on already-battered economies the risk of the holiday company's demise. Around 50,000 holidaymakers in Greece, 21,000 in Turkey, 15,000 in Cyprus, and 4,500 in Tunisia were stuck. Thousands of tourists in the US and dozens of other countries were also stuck, an estimated 150,000 visitors were from the UK followed by the tourists from Germany - 140,000 holidaymakers (Hayden-Lefebvre, 2019).

\section{1. Spain}

Melisa Rodríguez, a Spanish politician and delegate for Tenerife (the largest of Spain's Canary Islands), said that the failure of Thomas Cook could affect the Spanish economy and the Canary Islands in particular. She requested response from Spain's caretaker administration. In September 2019, about 525 Thomas Cook planes, mostly carrying visitors, were scheduled to travel to Spanish airports, wich was about 70 percent of UK-Spanish routes. Rodríguez said there were already 30000 people stuck on the Canary Islands and 3000 on the Balearics (Neate \& Smith, 2019).

"Fuerteventura's Queen", which exclusively had a contract with Thomas Cook, covering $95 \%$ of its 688 rooms until 2023, became the first hotel on the islands to close its doors due to the the company's failure that effected the local tourism. 160 employees hat to be laid off and at least 3400 other industry involved workers had to bear that burden according to projections (Badcock, 2019).

\section{2. Greece}

Thomas Cook became Greece's biggest UK holidaymakers' provider, sending three million tourists a year to the islands and hiring 1,000 people on site. Thomas Cook franchised deals with almost 50 Greek hotels. On Crete, where it was estimated that 20000 travellers were marooned, tourism officials compared the company's failure to a huge earthquake that would 
reverberate long through the economy. Michalis Vlatakis, president of Crete's travel bureaux and travel agents said that the problem was not only that all contracted tourists that had arrived were already gone, it was also in contracts that did not materialize as tourists scheduled to arrive before November 10 in 2019 just are not going to arrive (Neate \& Smith, 2019).

\section{3. Turkey}

According to the company's website, Turkey was the second most popular summer destination for Thomas Cook vacationers in 2019. That means plenty of visitors were stranded - about 21000 . The crash also poses a blow to the tourism sector in the region, which is a core pillar of the Turkish economy. Turkish officials said thousands of hotel workers were in danger when another company joined Turkish hotel chains as a partner. "Some hotels served for Thomas Cook alone" said Osman Ayik, president of the Federation of Turkish Hoteliers (McCormick, 2019).

\section{4. Tunisia}

For example in such low-middle-income countries such as Tunisia, tourism was not only accounting for $8 \%$ of economic growth but also empoyeed around 400000 workers (Hayden-Lefebvre, 2019).

\section{Conclusion and Recommendations}

The incident of BREIXT, if finalized will reflect on the policy design across the regional representatives. In the light of Thomas Cook bankruptcy, the competitiveness of tourism companies will be highly impacted through specialization, employment and export will be highly volatile. Especially the service sector which represents around 80 per cent of the UK economy, while manufacturing represents 10 per cent (Levarlet et al., 2018).

In conclusion, the loss of the tour operator placed 22000 jobs at risk, including 9000 in the United Kingdom. Although the fall of Thomas Cook impacts about 150000 Britons, the business had about 350,000 to 450,000 clients worldwide. Holidaymakers got home via free flights booked at no extra cost through another scheduled airline with details on the official website. The CAA (Civil Aviation Authority) contacted Thomas Cook hotels that were booked as part of a package to notify them that the tourists costs will be covered by the government via the Air Travel Trust Fund and the licensing scheme for Air Travel Organizers' Licensing (Atol) (BBC, 2019). However, Thomas Cook was lucky to shut down in September 2019 because if the government provided them with a loan at that time the company would have gone into a bigger debt due to the Coronavirus (COVID-19) which grounded many airline companies like the British airline Flybe. In March 2020, the British airline Flybe crashed as a result of the recent coronavirus outbreak that brought the carrier its final blow. The airline has been failing for quite a time. The UK government announced in January that its finances debated and the management of Flybe and the airline's shareholders put the airline "on the road to recovery", but Flybe was "complemented by a coronavirus outbreak that had a serious impact on the market in recent days", said the airline (Toh, 2020).

Companies need to avoid market failure through various steps. First, companies should be updated day to day with the new technology, since it became one of the essential things in peoples' lives and can be the easiest way to gain profits. Second, if there are competitors, the company needs to be unique among them with its their promotions, discounts, and packages. Third, through advertising the preferences of customers are changing. Fourth, balancing the expenses, considering government costs expenditures. The company needs to equilibrium transaction costs and government costs. 


\section{References}

Badcock, J. (2019, October 13). Thomas Cook collapse a big threat to Spain's tourist industry. BBC. Retrieved August 13, 2020 from https://www.bbc.com/news/worldeurope-49997775

BBC News. (2019, September 23). Thomas Cook collapses as last-ditch rescue talks fail. Retrieved from https://www.bbc.com/news/business-49791249

Corporate Finance Institute. (2015). Market Failure - Definition, Causes, and How to Address. Retrieved from https://corporatefinanceinstitute.com/resources/knowledge/economics/market-failure/

Dollery, B. E., \& Wallis, J. L. (1997). Market Failure, Government Failure, Leadership and Public Policy. Journal of Interdisciplinary Economics, 8(2), 113-126. Doi: 10.1177/02601079x9700800202

Economic Investigations. (2015, September 9). Handout: Barriers to Entry - Tour Operators. Retrieved from http://peped.org/economicinvestigations/handout-barriers-to-entrytour-operators/

Evans, K. (2019, February 11). Barriers to Entry in the Airline Industry. Biz fluent. Retrieved from https://bizfluent.com/list-7576197-barriers-entry-airline-industry.html

Hayden-Lefebvre, T. J. (2019, September 29). The Impact of Thomas Cook's Collapse on Tourism. Simple Flying. Retrieved from https://simpleflying.com/thomas-cookcollapse-tourism/

Hazledine, T. (2010). Oligopoly price discrimination with many prices. Economics Letters, 109(3), 150-153. doi:10.1016/j.econlet.2010.09.009

Hernandez, V. (2020, January 16). The Collapse of Thomas Cook: What Happened and Why. International Banker. Retrieved from https://internationalbanker.com/brokerage/thecollapse-of-thomas-cook-what-happened-and-why/

Kollewe, J. (2019). Brexit chaos hits Thomas Cook as losses mount to£ $1.5 \mathrm{bn}$. The Guardian. Available at: https://tinyurl.com/y42xjyzt.

Leadbeater, C. (2019, September 20). The history of Thomas Cook, from tours for teetotallers to boozy packages in Spain. The Telegraph. Retrieved from https://www.telegraph.co.uk/travel/tours/history-of-thomas-cook/

Levarlet, F., Seri, P., Zingaretti, C., Hrelja, D., \& Lorgeoux, E. (2018). Assessing the Impact of the UK's Withdrawal from the EU on Regions and Cities in EU27. European Committee of the Regions. Doi:10.2863/572180. Retrieved from https://op.europa.eu/en/publication-detail/-/publication/38798c7b-387c-11e8-b5fe$\underline{01 \text { aa75ed71a1 }}$

McCormick, M. (2019, September 23). Thomas Cook: Collapse of UK's oldest travel group reverberates around the world - as it happened. Financial Times. Retrieved from https://www.ft.com/content/18c6356f-d806-3fef-9ff7-29fb80a343c7 
Neate, R., \& Smith, H. (2019, September 23). Fallout from Thomas Cook collapse felt across Europe and Africa. The Guardian. Retrieved from https://www.theguardian.com/business/2019/sep/23/fallout-thomas-cook-collapsefelt-across-europe-africa

Rubin, R. M., \& Joy, J. N. (2005). Where are the airlines headed? Implications of airline industry structure and change for consumers. Journal of Consumer Affairs, 39(1), 215-228.

Sims, S. (2019, September 23). How Could Travel Giant Thomas Cook Fail? The New York Times. Retrieved from https://www.nytimes.com/2019/09/23/travel/why-thomascook-travel-collapsed.html

Stavins, J. (1996). Price Discrimination in the Airline Market: The Effect of Market Concentration. Review of Economics and Statistics. Doi/10.1162/rest.2001.83.1.200

Stubley, P. (2019, May 16). Thomas Cook blames Brexit for $£ 1.5$ bn loss. Independent. Retrieved from https://www.independent.co.uk/news/business/thomas-cook-shareprice-profit-loss-results-brexit-travel-flights-a8916061.html

Thomas Cook. (2019, September 23). Share Price. Retrieved from https://www.thomascookgroup.com/investors/share_price

Thomas cook annual report (2018). Thomas Cook Group plc. Retrieved from: https://www.annualreports.com/HostedData/AnnualReports/PDF/LSE_TCG_2018.pd $\underline{\mathrm{f}}$

Toh, M. (2020, March 5). UK airline Flybe collapses as coronavirus crisis deals the final blow. CNN Business. Retrieved from https://edition.cnn.com/2020/03/04/business/flybe-collapse-2020/index.html

Whyte, P. (2019, September 30). Debt, Egos and Bad Decisions: How Thomas Cook Failed to Adapt to a New Era of Travel. Skift. Retrieved from https://skift.com/2019/09/30/debt-egos-and-bad-decisions-how-thomas-cook-failedto-adapt-to-a-new-era-of-travel/ 


\title{
IMPORTANCE OF THE MARKETING ENVIRONMENT ANALYSIS IN THE PROCESS OF STRATEGIC MARKETING DECISION MAKING
}

\author{
DILYANA YANEVA ${ }^{1}$
}

\begin{abstract}
The analytical activity aims to increase company's competitiveness and establish its strategic position in the business. Timely diagnosis of threats, identification of key success factors and competitive advantages enables company management to constantly review its marketing goals and strategies by taking proper and timely strategic marketing decisions.

In this regard, the main objective of the article is to examine the characteristics and main directions of marketing analysis, emphasizing their importance in the process of strategic marketing decision making. A survey was used as a main method for collecting primary data. The evaluation of the studied indicators is performed on a 5-point Likert-type scale. The obtained results show the underestimated role of the environment analysis in the companies' marketing activity and its necessity in decision making for a long-term development and prosperity. The conclusion includes a summary concerning the overcoming of these problems.
\end{abstract}

Keywords: marketing analysis, marketing environment, strategic marketing decisions, strategic marketing decision making process

JEL Codes: M10, M30, M31

\section{Introduction}

In today's dynamic market conditions and relationships, the optimization of marketing efforts is invariably associated with successful strategic marketing planning. A key role in this process is the analytical direction of marketing activity that helps company to get acquainted with the state and capabilities of its own business, trends in economic conditions and market, power and strength of stakeholders. Due to this, a real and timely assessment of the marketing environment impact on the company's condition and development could be made.

The main aspects of the analytical activity are the research of the economic, social, technological and other factors; examination of the market characteristics, trends and opportunities; analysis of consumers, competitors, suppliers; assessment of the company's potential, problems, etc.

Pehlivanov (2006, p. 67) defines the research function as the main one in the process of marketing management. According to the author it allows to find the most profitable for the company opportunities for the products' realization and determination of the strategy and tactics based on the previously diagnosed market risks. Kyurova (2014) notes its importance for the entrepreneurial business as it allows control of external factors and identification of strategic alternatives (p. 86). It can also be added that marketing analysis serves as a starting point for defining marketing goals.

\footnotetext{
${ }^{1}$ Faculty of Economics, Department of Management and Marketing, South-West University "Neofit Rilski”, Blagoevgrad, d janeva@swu.bg,

ORCID iD https://orcid.org/0000-0003-3472-4595
}

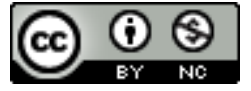

This work is licensed under a Creative Commons Attribution-NonCommercial 4.0 International License. 
"The companies of twenty-first century increasingly need managers who can think and act strategically" (Planellas \& Muni, 2019). The strategic decision precess has three main stages: analysis, decision and implementation (Planellas \& Muni, 2019, p. 2). Therefore, strategic marketing decisions aim to create a system of preventive measures and protective mechanisms to counteract the negative effects of the dynamic external and internal business environment. They are based on the idea of creating sustainable competitive advantages and key competencies by finding strategic opportunities for company development. This is unthinkable without the use of reliable timely market information and appropriate marketing mechanisms and approaches. In this regard, Karakasheva, Mencheva and Markova (2001, p. 16) emphasize that the effect of any marketing and management decision is determined by the quality, volume, specificity and content of the information that is collected and processed for the purpose.

Based on the above, it can be concluded that marketing analysis is the basis for the right strategic marketing decision making. However, in order to better understand the importance of marketing analysis, it is necessary to consider their main characteristics and directions.

\section{Features of marketing analysis}

An important condition for understanding the analytical activity and its importance in the process of making strategic marketing decisions is the consideration of its main functions - descriptive, explanatory and predictive. The obligatory parameters are purposefulness, objectivity, timeliness and orderliness (Zaharchenko \& Kuznetsov, 2005, p. 20-22).

The effective analysis of the marketing activity is determined by the established and maintained marketing information system of the company (MIKS). Its main components include a variety of equipment, technology, capabilities, organization, management (Karakasheva et al., 2001, p. 17), procedures, methods and marketers (Kotler, 1994). Extremely important for the detection of the condition, trends, deviations and reasons for the obtained results is the marketing primary and secondary information. It can be said that the strategic orientation of the company's activity is built on its basis. It is no coincidence that Tsiakis (2015) argues that "strategic information, domain knowledge and guidance within systematic strategic analysis are vital for managers to support strategic operation of firms such as marketing strategy development".

The algorithm of the marketing analysis process consists of seven main stages:

- determination of the marketing analysis object (symptoms causing discrepancy in the company management system);

- $\quad$ setting goals;

- creation of a plan of the analysis;

- developing a schedule for collecting and processing information;

- systematization of the received data;

- information analysis;

- development of conclusions and recommendations based on the conducted analysis (Zaharchenko \& Kuznetsov, 2005).

An important aspect, in relation to the studied issues, is the Feasibility Study Model. In order to move from current state to desired state, the company must study a number of factors such as risks, options, resourses, time frame, location and stakeholders. The key role in the model is played by the feasibility analysis levels: departmental/unit factors, business level factors, industry and market segment level factors and macroenvironment factors PESTEL (Kampira, 2018). 
At the same time, it is necessary to consider the main directions of marketing analysis. The literature review shows a diversity of the opinions of the authors. Based on the literature review, there is a divergence in the opinions related to the main directions of the marketing analysis. For a number of authors they include market analysis, analysis of the market opportunities and consumer behavior; industry analysis; competitor analysis (Madgerova et al., 2012). Marinova (2014) considers that analytical activity should be viewed through the prism of the external marketing environment (general economic, market and competitive environment); marketing activity (sales volume, market share, profit, marketing procedures, marketing organization, control, marketing mix) and the marketing system (marketing goals, strategy, rights and obligations of marketing specialists, information system, planning, control, interaction, profitability analysis, etc.). However, Kyurova (2014) maintains that the marketing environment is crucial in this process. The author considers two main types of analysis - the external environment (industry and competitive analysis) and the internal environment (analysis of the market, market share, sales, marketing costs and marketing potential).

Our opinion is that the marketing environment is a reliable indicator for the analysis of the company's marketing activity. Including all the driving forces that influence business directly or indirectly (Palmer \& Hartley, 1999), marketers prioritize factors such as the emergence of new consumer tastes and needs, the development of information and communication technologies, free access to information, global and multicultural relations, analysis of company resources, opportunities and potential.

In this regard, our thesis is that it is appropriate to consider the main directions of marketing analysis as: external macro, external micro and internal marketing environment.

\section{Main directions of marketing analysis}

\subsection{Analysis of the external macro marketing environment}

The macro-environment consists of difficult to predict factors that are not subject to control by the enterprise. They are highly dependent on each other, and their influence is different for each company (Kyurova, 2014).

After the literature reference, the major factors - the subject of the study, are grouped into economic, demographic, socio-cultural, technological, political and legal, climatic and ecological. Among them, special attention should be paid to the indicators of market conditions, financial stability, industry attractiveness, lifestyle changes, culture and perceptions, innovation and technological development, climatic and environmental changes, regulatory measures, restriction and promotion of business, etc.

The choice of method for analysis and evaluation of the external macro environment depends on the experience, capabilities and views of the company management. Looking for changes in the pre-defined profile of environmental factors, it is appropriate to use econometric modeling, extrapolation, risk forecasting, correlation and regression method, scenario methods, experiment, PEST-analysis, PESTLE-analysis.

\subsection{Analysis of the external micro marketing environment}

The micro environment includes all actors close to the organization that influence (positively or negatively) on its ability to serve customers - to create value and build relationships with them (Kotler \& Armstrong, 2010, p. 90). The literature review reveals that these are consumers, shareholders, investors, owners, company employees, competitors, suppliers, government agencies and other organizations. It is evident that the main importance of this type of analysis is the acquisition of knowledge about the state and trends in the market situation, the competitive company position in the market, changing tastes and increasing requirements of consumers, the supply system, etc. 
The analyzes that must be applied to study the external micro environment are analyzes of the industry, consumers, competitors and suppliers.

The main parameters related to the industry and subjected to research are its structure, dynamics and attractiveness. The aim is to identify threats, drivers and key success factors. Emphasis is placed on employment, competition, life cycle, production, sales, profitability, investment, innovation, etc. Milusheva (2012, p. 106-108) groups them into five categories: factor conditions, demand conditions, related and supporting industries, company strategies, structure and competition, government. Mladenova (2006, p. 87) also raises the question of the process algorithm including the determination of the structure-determining conditions supply and demand; market and industry structure; functioning and results.

The comparative analysis of competitors is aimed at a detailed study of their number, concentration, market share, profitability, sales, corporate image, goals, strategies, tactics, etc. This would help to determine the state of competition, thus will stabilize the market position of the company, build its competitive advantages and choose the most profitable competitive strategy that will help to increase the company's competitiveness.

For the purposes of this article, it is appropriate to consider the consumer survey. An important condition is to analyze comprehensively consumer needs and tastes. This is necessitated by the development of the „4P" concept which has become „4C" concept in recent years. At its center is placed the consumer with the customer value, customer costs, convenience and communication (Ivanov, 2015, p. 4). The main indicators that are subject to analysis and evaluation are the attitude of customers to the company and brand, level of satisfaction with products and services, motivation for purchase, interests and preferences, etc. Thus, with the help of the developed customer profile, the company will build an effective model of consumer behavior that will help it to make the right strategic marketing decisions.

Regarding to the suppliers' analysis, it is necessary to study the supply system and suppliers - their company image, experience, financial stability, quality of materials, scope, contract terms, prices, deadlines, after-sales service, etc.

\subsection{Analysis of the internal marketing environment}

The need to study of the internal marketing environment factors is related to their direct impact on the company's activities and prosperity. The main analyzed indicators are market efficiency, production capacity, financial resources (Havaldar, 2005, p. 26), company culture and corporate image.

Detailed examination of the literature on the issue shows the use of a variety of analyzes: market analysis, analysis of the business portfolio, market share, sales, distribution, costs, profit, etc. However, in clarifying the nature of the internal analysis, the importance of both quantitative and qualitative parameters should be mentioned.

In our opinion, the key role in the strategic decision-making process is played by the study and evaluation of the company's resources, opportunities and potential. They are the basis for building sustainable competitive advantages, which is a prerequisite for permanent establishment of the company on the market.

Grant (2015, p. 116-119) has contributed to the theory, which considers company resources as tangible, intangible and human resources. The indicators that can be used in their analysis are financial (profit, financial return, liquidity), production (productivity, number of hours of equipment operation), marketing (sales volume, sales costs, degree of customer satisfaction, number new customers) and indicators related to management (efficiency of orders, efficiency of personnel management). 
The building of key competencies is the basis of the study of company opportunities. Functional analysis and value chain analysis are essential for their understanding. The first type of analysis identifies the organizational capabilities in each of the company functional areas (Grant, 2015, p. 123). The value chain matrix is considered by Porter (1985) as a starting point for the development of company strategies. The author argues that through the main operations (incoming logistics, operations, outgoing logistics, marketing, sales, services) and supporting activities (infrastructure, technological development, HRM, delivery), the construction, establishment and stabilization of the company's competitive advantages is achieved.

The analysis of the company potential deals with the construction of a company profile, based on the identified problems and opportunities for the company development. The objective is to achieve the set goals by laying the foundations for building a corporate strategy and making strategic decisions for business success.

The company's potential should be considered in the following areas: financial and economic, potential of production opportunities, technological, market and human resources. Factors that the marketing team must consider are finance, personnel, leadership style, marketing, goods and services, production, market, supplies, exclusive opportunities, efficiency (Goncharuk, 2000). According to Linkevich and Gulmanov (2011, p. 29) the main analyzed indicators are summarizing (potential efficiency), differentiating (labor productivity) and functional indicators (market activity, market share).

In this case, the role of the Analytical Hierarchic Process (AHP) approach, considered by Tsvetanova \& Veleva (2014), is also very important. It helps not only to define the market potential and key competencies, but also to determine the relative position in relation to competitors and the sustainability of the company's potential.

From the above it is clear that marketing analyzes are directly related to the strategic planning and management of the company and play a key role in the process of strategic marketing decisions. However, it is necessary to study what marketing analyzes are performed in Bulgarian companies and what is their role according to the company management.

\section{Results and Discussion}

The study used data from a questionnaire-based survey, conducted in June - July 2019, of 132 managers and owners of enterprises in the field of production, trade and services in Blagoevgrad district, Bulgaria. The object of the study is to reveal the extent to which the analytical activity in the company's marketing management is represented and whether its importance in the process of strategic marketing decision making is realized.

The distribution of the enterprises in the sample according to their field of activity shows a predominance of those in the field of services (59.1\%). The rest are manufacturing (9.1\%) and trading companies $(31.8 \%)$. It is established that micro-enterprises are $52.3 \%$, small $-27.3 \%$, medium $-6.8 \%$, and large companies $-13.6 \%$ of respondents. The distribution of enterprises according to the period of their establishment is as follows: $2.3 \%$ - up to 1 year, $25.1 \%$ - from 1 to 5 years, $18.2 \%$ - from 5 to 10 years and $54.4 \%$ - over 10 years.

An important point is the organization of the company's marketing activities, as in our opinion it shows the level of perception of the marketing approach in corporate management.

Presented results of the study show the lack of a reliable company marketing structure. It is found that only $22.7 \%$ of the companies have a marketing department. $4.5 \%$ of the enterprices have one marketer. Marketing activities in many companies are carried out by other company departments $(27.3 \%)$ or marketing agencies $(50 \%)$. In $9.1 \%$ these activities are performed by the manager and in $2.3 \%$ - by the owner. It is noteworthy that $22.7 \%$ of the 
companies give priority to their marketing activities only when a problem is identified. In these cases, a temporary working group of employees is formed.

Regarding the analyzes performed by the companies, it turns out that the companie's study mainly the external micro environment. The least attention is paid to the analysis and evaluation of the internal company environment. Let us take a closer look at the different areas of the company's analytical activity.

The majority of managers claim that they mainly monitor the current state of the external macro-marketing environment. $65.9 \%$ of them believe that it is very important for the company's prosperity. At the same time, for $54.6 \%$ it is extremely important to study the trends in its future development. $34.1 \%$ of managers believe that this type of analysis is partly significant and for $4.5 \%$ it is absolutely irrelevant.

Figure 1. Importance of the researches of the external macro marketing environment for the enterprise development

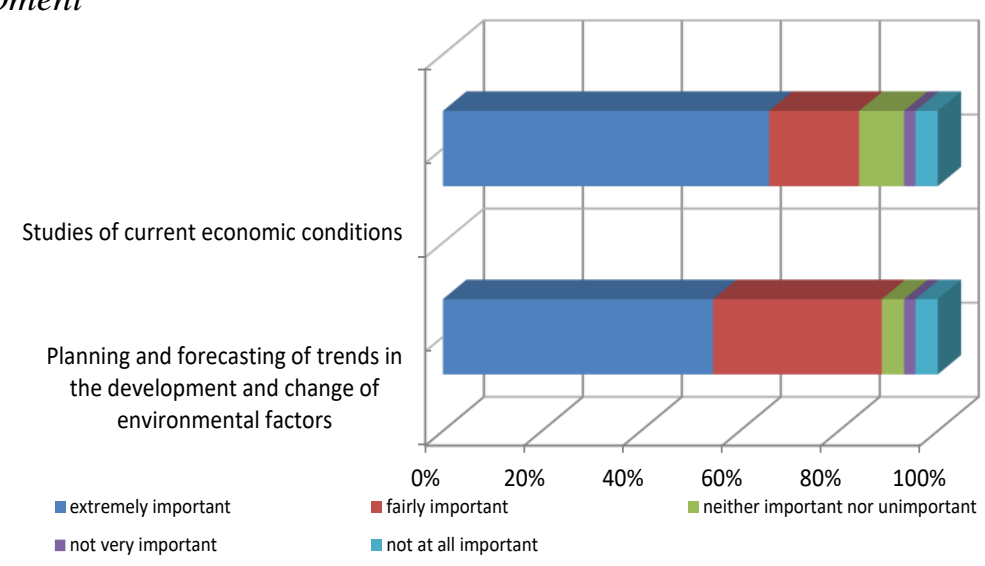

Source: own calculation based on surveys' results

As regards the external micro-environment, increased attention is paid to consumer research. It is defined as extremely significant by $75 \%$ of the respondents. However, it is necessary to consider what this type of analysis contains.

Figure 2. Importance of the researches of the external micro marketing environment for the enterprise development

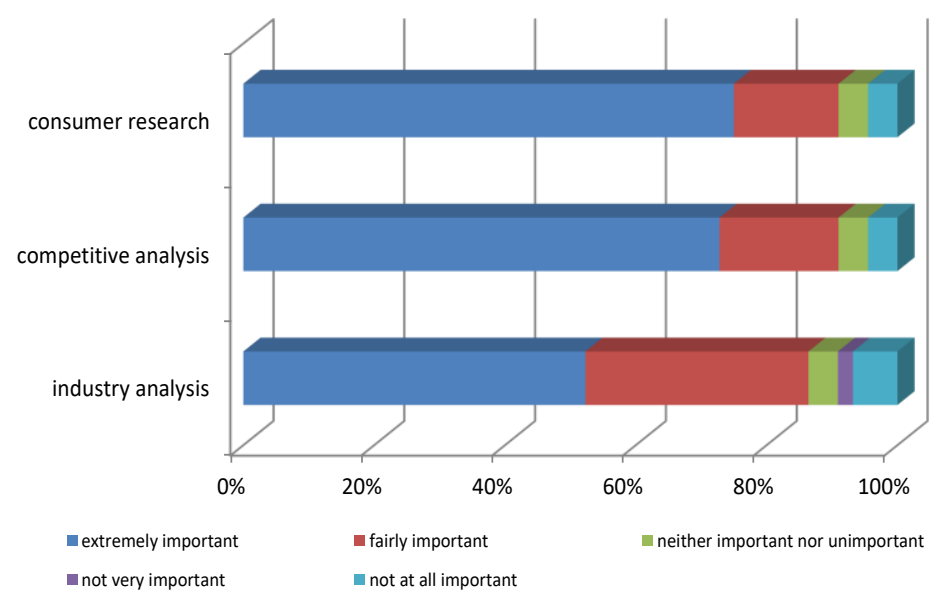

Source: own calculation based on surveys' results

In the first place is the analysis of consumer demand and current consumer preferences $(79.5 \%)$, followed by studies of trends and changes in needs $(72.7 \%)$ and the 
number and concentration of market segments (56.8\%). $29.5 \%$ of enterprises pay attention to the consumer behavior and $27.3 \%$ to the attitude to similar competing goods.

Competitive analysis is very important for $72.8 \%$ of respondents. Nodal is the place of study of competitive products $(81.8 \%)$, price policy $(81.8 \%)$, consumers $(61.4 \%)$, communication and advertising policy $(56.8 \%)$, sales volume $(54.5 \%)$, distribution channels (52.3\%), number of competitors (47.7\%), scope of action (45.5\%). Paradoxically, very few respondents study the goals and strategies of their competitors (respectively $38.6 \%$ and $43.2 \%)$.

It turns out that $52.3 \%$ of respondents believe that industry analysis contributes to corporate development.

The results concerning the internal analysis show that for $65.9 \%$ of managers the importance of financial indicators (productivity, profit, costs, etc.) and non-financial parameters (corporate image, staff motivation, need for additional training, etc.) is crucial. On the other hand, the importance of the study of the company's marketing activity is underestimated. $27.4 \%$ of respondents consider it partly essential, $4.5 \%$ rather insignificant, and $6.8 \%$ believe that it has absolutely no meaning.

Figure 3. Importance of the researches of the internal marketing environment for the enterprise development

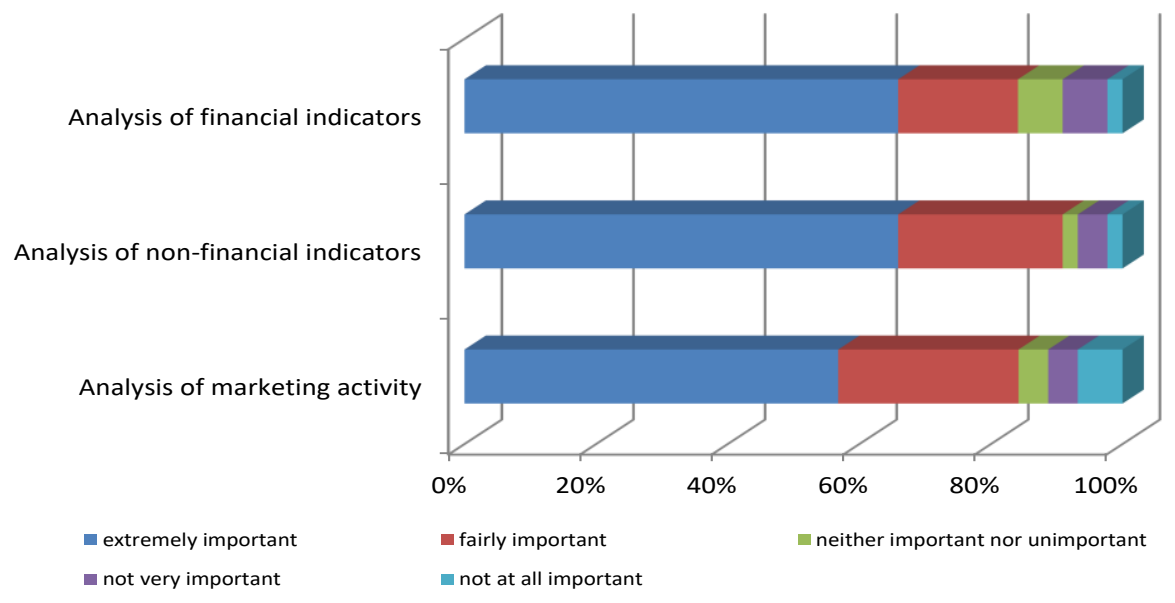

Source: own calculation based on surveys' results

\section{Conclusion and Recommendations}

Based on the above, some findings and essential summaries can be made to serve a better understanding of the marketing analysis importance in the effective and timely strategic decision making.

The results of the study reveal significant gaps in the marketing activities of the enterprises in Blagoevgrad district, Bulgaria. The lack of a reliable organizational structure of marketing activities has a serious negative impact on the overall process of strategic marketing planning. Insufficient use of marketing analysis interferes the timely diagnosis and management of the threats from the external macro environment and the use of business opportunities. Despite the priority attention to consumers and their needs, there is a neglect of the goals and strategies of competitors. The role of the internal analysis and especially of the marketing activity, affecting the strategic research and evaluation of the company resources, opportunities and potential, is also underestimated. This hinders the building of key competencies and stable competitive advantages and has a direct impact on the growth, competitiveness and lasting establishment of companies in the market. 


\section{References}

Goncharuk, V. A. (2000). Enterprise development. M. Case. http://devbiz.narod.ru/home/kozloff/Management/EntDevGoncharuk.pdf

Grant, R. (2015). Contemporary strategy analysis: text and cases edition. 9th Ed., Chichester: John Wiley \& Sons. ISBN 9781119120841

Havaldar, K. (2005). Industrial marketing: text and case. $2^{\text {nd }}$ Ed., New Delhi: Tata McGrawHill Education. ISBN 0-07-058840-6

Ivanov, P. (2015). Стратегически маркетинг - реалност и перспективи [Strategic marketing - reality and perspectives]. Бизнес посоки, 2, 3-8. Retrieved from https://bjournal-bfu.bg/uploads/posts/2015_2_03-08_bg.pdf

Kampira, A. (2018). Feasibility Studies: New Product Development and Launch, Pretoria: Abisha Kampira. Retrieved from https://tinyurl.com/yauvmu9x

Karakasheva, L., Mencheva, L., \& Markova, B. (2001). Маркетинг [Marketing]. Призма. София. ISBN 954-8571-11-0.

Kotler, P. (1994). Marketing management, analysis, planning, implementation, and control. London: Prentice-Hall International.

Kotler, Ph., \& Armstrong, G. (2010). Principles of marketing. New Jersey: Pearson Education. Retrieved from https://tinyurl.com/y8m5ulxe

Kyurova, V. (2014). Маркетинг в предприемаческата дейност [Marketing in entrepreneurial activity]. УИ „Неофит Рилски“. Благоевград. ISBN 978-954-680923-0].

Linkevich, V., \& Gulmanov, S. (2011). Методика анализа эффективности потенциала компании [Methodology for analyzing the effectiveness of the company's potential]. Экономический анализ: теория и практика, 10(6). Москва: Финансы и кредит. ISSN 2311-8725 (Online), ISSN 2073-039X (Print)

Madgerova, R., Georgiev, G., Karashtranova, E., Kyurova, V., Terziyska, I., Stavrova, E., Dimitrova, R. (2012). Организация и управление на малкия бизнес [Organization and management of small business]. Langov. Blagoevgrad. ISBN 978-619-90031-2-1

Marinova, N. (2014). Подходи в планирането и организацията на маркетинговата дейност [Approaches in the planning and organization of marketing activities]. Tenth anniversary scientific conference with international participation ,, Space, ecology, safety “, 465-470. София. Retrieved from: http://www.space.bas.bg/SES/archive/SES\%202014_DOKLADI/4_Ecoclogy/19_Mar inova.pdf

Milusheva, V. (2012). Методи за оценка и анализ на конкурентоспособността на индустриалната фирма [Methods for assessment and analysis of the competitiveness 
of the industrial company]. Икономически и сочиални алтернативи, 4, 102-117. София. Retrieved from https://www.unwe.bg/alternativi/bg/journalissues/article/5064

Mladenova, G. (2006). Маркетингово планиране [Marketing planning]. УИ Stopanstvo, София.

Palmer, A., \& Hartley, B. (1999). The business and marketing environment. Europe, Middle East \& Africa: McGraw-Hill. ISBN 0077094948, ISBN 9780077094942.

Pehlivanov, V. (2006). Курс по маркетинг [Marketing course]. Галик, София.

Planellas, M. (2019). Strategic Decisions: The 30 Most Useful Models. Cambridge University Press. ISBN 978-1-108-48624-8, ISBN 978-1-108-73195-9.

Porter, M. (1985). Competitive advantage: creating and sustaining superior performance. New York: The Free Press. ISBN 0-684-84146-0.

Tsiakis, T. (2015). Trends and innovations in marketing information systems, advances in marketing, Customer relationship management and e-services, Harrisburg: Idea Group. ISBN10: 1466684593, ISBN13: 9781466684591.

Tsvetanova, A., \& Veleva S. (2014). Determining the potential of company activities to achieve competitive advantage, International Forum - Albania, E-University, Sofia: TU. Retrieved from https://e-university.tu-sofia.bg/e-publ/search-det.php?id=1522.

Zaharchenko, V., \& Kuznetsov, E. (2005). Стратегический маркетинг на предприятии [Strategic marketing of the enterprise] Одеса: Наука и техника. Retrieved from https://tinyurl.com/y7js473w 


\title{
EGYPTIAN FEMALE ENTREPRENEURSHIP AS DRIVING FACTORS IN THE DIGITAL ERA, A HOPE OR A CHALLENGE
}

\author{
DOAA SALMAN ${ }^{1}$ \\ ABEER RASHDAN ${ }^{2}$ \\ LAYLA AMR ${ }^{3}$
}

\begin{abstract}
This paper attempts to critically analyse the driving factors that affects Egyptian female employability in the digital sector. On the other hand, investigates the challenges that female face in the business world, in the light of the entrance of Egypt in the digital era and governments efforts to achieve the sustainable development goals. Currently, Egyptian females have a better chance than ever in becoming entrepreneurs. The aim of the paper is to analyse some of the factors that affect female as employers and draws a clearer image to what factors could help increasing female employability in Egypt during the period from 1991 to 2019.

This study used Augmented Dickey Fuller (ADF) test to check stationarity of variables. On the basis of results of ADF test, ARDL approach of cointegration was applied. Results show that internet ratio has positively affected female employability, while laws have not affected it significant. Finally, conclusion and policy recommendation are proposed.

Based on the study findings that show that female opportunities on Egyption labour market need to be accompanied with schools and universities education development in order to equip them with digital knowledge and skills necessary in the digital era. Also, government policies and laws are still needed to consider female as an engine to growth.
\end{abstract}

Keywords: Female entrepreneurship, SDGs, Financial inclusion, Digital Era, Digitalization

JEL Codes: A2, J16, L25, 126

\section{Introduction}

Females in the United States were not allowed to own land or properties and if a female by law had lands and got married the entire ownership of her properties were given to her husband according to the "The Married Women's Property Act" of 1848, considered one of the most important estate laws in the United States (Shammas, 1994). For example, in 1929 Canada finally included women in the legal definition of "person" which means that until 1929 a woman in Canada was not even considered a person. After that women were given the right to become a member of Canada senate and increase their political participation. According to the World Bank, women are almost half of the population of the world countries but they are still unable to hold properties or to assert equal rights or protection when it comes to their estates (World Bank, 2019). "For men and women alike, land is the foundation for security, shelter,

\footnotetext{
${ }^{1}$ Prof. of Economics, Head of the Economic Department, October University for Modern Sciences and Arts, Cairo, Egypt, dsalman@msa.eun.eg,

ORCID iD https://orcid.org/0000-0001-5050-6104

${ }^{2}$ Lecturer of economics, Future university in Egypt, i_abeer@ hotmail.com, ORCID iD https://orcid.org/0000-0002-8703-3926

${ }^{3}$ October University for Modern Sciences and Arts, Cairo, Egypt, layla.amr@ msa.edu.eg, ORCID iDhttps://orcid.org/0000-0002-8657-2493
}

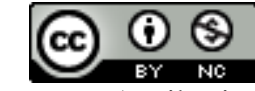

This work is licensed under a Creative Commons Attribution-NonCommercial 4.0 International License. 
and livelihood, supports women's dignity and creates pathways to empowerment and economic opportunity," said Karol Boudreaux, Chief Program Officer with the land rights group (World Bank, 2019). Thus, the discrimination against women continues in many fields especially in the business sector. The economy of our world is a very important factor for the survival of every country and women are an essential part of this economy as they makeup almost half of the world's population. So, if equal chances were presented the world's economy would blossom and reach new levels that will boost our economy.

The Egyptian culture was not fair to its females but was one of the main examples to how females were unequal to males throughout history. Consequently, even when females were able to hold jobs their entire earnings would go to their fathers or husbands. Year after year and century after century females were denied of their basic rights in Egypt. Females in Egypt weren't allowed to have an education unless they were born to a rich family which shows a huge level of inequality and discrimination (Zuhur, 2001). This level of inequality was transferred for centuries and until this day with everything that changed over time still a lot of people believe that females shouldn't be educated or take part in the labour force. According to the World Bank, in 1978 the illiteracy rate in adult females was over 80\% which means that $80 \%$ of females were never offered an education. However, after many stages and fights for female rights in Egypt this ratio improved but there are still over 35\% of illiterate adult females in Egypt in 2019 which clearly shows the cultural inheritance of female inequality in Egypt (World Bank, 2019).

As the technological factor has been lingering for years and economies that invest in technology end up winning as technology is considered the future of our world. Egypt has been one of the countries that has been working on improving the technological factor within the country and although the move towards digitalization has been going on for years now. The latest pandemic COVID-19 and the countries going on lockdown has improved the technological use globally and in Egypt was forced to enter a new stage of awareness of the technology importance and especially the information and communication technology. COVID-19 pandemic had worked to promote ICTs better than the country could have and now it became the true beginning of the digital era in Egypt. With the help of the previous information this research will try to answer the question of what is stopping Egyptian females from becoming entrepreneurs, will discuss the factors that affect the female entrepreneurship, and will find ways that could finally help the Egyptian female in increasing her employability and entrepreneurship chances. Egyptian females suffer from low employability levels due to factors that include but are not limited to, qualifications, social standards and how the society looks at women. These problems are not just faced by women in the work environment but also in their education, according to the World Bank 2017, only $12.67 \%$ of females in Egypt at least complete their post-secondary education. This among many other factors affect the female level of employability and their entrepreneurship chances.

Looking over all the previous factors its clear how females suffer from a problem in the work and business environment in Egypt. But this problem in Egypt is spread to the core of the Egyptian traditions and cultural beliefs which discriminates against women and is the reason for how they are not offered enough chances to be able to hold decent jobs or become entrepreneurs in the Egyptian community which is the core of the female entrepreneurship problem in Egypt. With our world trying to achieve a more sustainable environment especially with the goal to achieve the sustainable development goals - SDG (from the development goals the fourth goal which is quality education, the fifth goal which is gender equality, the $8^{\text {th }}$ goal which is decent work and economic growth and the tenth goal which is reduced inequality), the focus on inequality and equal chances has been clearer and in order to move toward a more advanced world and a world with the basic rules of equality according to the SDGs goal the first step is to fight the discrimination against females as this will help our world develop to a 
much more advanced world. With digitalization at the door females will have a better chance to achieve their purpose and help the country prosper as well as to get Egypt closer to achieving the global goals of sustainability. In Egypt, the labour force needs to have more female's inclusion, in order to give Egyptian females better chances and let them have their position in the business world. Female employability factors should be kept into consideration in order to have them boosted by the digital era and the boost the world is getting by trying to achieve the 17 sustainable development goals by 2030. The question and the aim of the paper is to help understand the obstacles that hinder Egyptian females to join the business world. As well as how to prevent those obstacles by understanding their dynamics. Those barriers faced by females in Egypt or even by females globally are not new but they have been going on since the beginning of time and as much as they improve, they still need to be overcome so that females could have their rights and could help by being more productive members of their societies.

This study analyses factors and reasons to why females in Egypt are subjected to fewer chances than males in the business world and how to fix this problem for future generations by finding ways to improve them and allow females to have better chances for a better future. As the importance and purpose of this study is to address factors that will help females use and utilize technology to their advantage and find ways to give females a competitive advantage in order to be able to create better employment and entrepreneurship chances in the future. The following section will provide a literature overview for the role of female entrepreneur. Section three deploys the ANOVA test for determine the significant factors affecting female entrepreneurs. Finally, conclusion and policy recommendation

\section{Literature Review}

\subsection{Theoretical review}

Many females in developing countries are deprived from education. Historically, traditions and ideologies were totally against women's rights, especially the right to education (Russell, 1992). Males, however, were educated and held high positions in the country. Educational discrimination was not just against the female but it was also against the poor. So, the rich would get their males educated and even those rich people would most likely deny their daughters the same rights to education (Russell, 1992). However, Egypt was one of the countries that overcame this discriminatory loop before others. By the dawn of the1860s, the Egyptian government had started investing in its human resources by sustaining a good educational flow that the population benefited from completely. Scratch that, the male population benefited from completely. The Egyptian educational system was a core foundation for Egypt and most countries in Africa and the Middle East. As those countries depended on the Egyptian educational system to help them lay the foundation of their own educational system but even then, females would rarely benefit from such system (Shann, 1992). In 1908, a small institution, that was an art school, was established to offer classes in Literature, Economics, History and Philosophy. Over the time, this institution kept on growing until it morphed into the mother of all universities in Egypt and Arab countries to become the prestigious Cairo University. According to Shann (1992), many of the faculty members of Middle Eastern and African countries completed their higher education in Egypt. Currently, the Egyptian government's aim is to overcome discrimination in education and it is a goal near to be achieved (Vakili, Tahmasebi, Tahmasebi \& Tahmasebi, 2016).

According to Zuhur (2001), the lack of female education was the main factor that drove the feminist movements that later helped the females to get an education. The movements improved the conditions for females in Egypt, but the odds were stacked against them due to cultural restriction reinforced by Egyptians. The Egyptian culture, until the 21st century, still believed that females should be nothing but housewives and still deny them their right to 
education. This educational factor is theoretically one of the main factors that affect female entrepreneurship. On the other hand, the business world in Egypt was mainly dependent on agricultural goods. The Egyptians used their land for agriculture since $8000 \mathrm{BC}$ and kept on utilizing the land until the late 1900s. According to Tucker (1976), only 3-4\% of the Egyptian labour force were females and even females who participated in the labour force were looked down upon and were treated unfairly. The rest of Egyptian females dedicated their lives to running chores and becoming housewives with no education nor a chance to step on a higher level on the labour market, obtaining a bigger part of the labour force (Tucker, 1976). When Egypt began moving towards industrialization and businesses started to bloom, the lack of education between females was one of the primary reasons to why they still didn't have a major participation in the industrial sector and remained as they were while males took over the industrial and business sectors (Crals \& Vereeck, 2005). Moving forward, the Egyptian economy kept on evolving to take on many new sectors which helped the economic development and put Egypt on the developing path with new small and medium enterprises every year and new job opportunities. But still females were denied in most of those opportunities due to the cultural attribute that has a high discrimination level against females and the previous lack of education and opportunities that they were subjected to over the years didn't help as well (Nambisan, Wright \& Feldman, 2019).

Putting all that aside, the most effective factors on entrepreneurship are the savings and investments. According to Tee (1987), savings is one of the important factors that affect investments as it creates the liquidity needed in order to start investing and with this available, liquidity finance for entrepreneurship will be available and will help entrepreneurs in starting new businesses, males and females are affected by the level of savings in each and every country. According to Quadrini (2009), entrepreneurship happens in the economy and is sustained if there's sustainable savings and investment and referred to the golden savings rule that indicates an increase in investment due to savings and in order to maximize benefits savings should be closer to $50 \%$ of income. All those theories prove the importance of savings and its major effect on entrepreneurship.

\subsection{Empirical review}

In a more advanced overview, in order to stop the barriers that are faced by female entrepreneurship in Egypt, the factors that affect the level of entrepreneurship should be addressed and analysed, alongside the type of the Egyptian job market and business environment as well. Those two important points are the main framework in finding a way to stop this lack of female entrepreneurship and employability (Mahrous, 2019). First, the Egyptian business environment and job market is divided to many sectors and many types of businesses. Ever since Egypt started its industrialization phase, Egypt has had many business sectors (Assaad, Krafft \& Yassin, 2020). The Egyptian market has been improved overtime and this benefited Egyptian females in terms of in job opportunities increase. However, Egyptian females just like African and some Middle Eastern females, suffer from a huge lack of education which reduces their qualifications in order to be competitive on labour markets which is one of the main reasons why females have a low employability chance (Assaad, Krafft $\&$ Yassin, 2020). Educational qualification is one of the most common barriers on most job markets and the lack of education takes away most of the job opportunities the female could get but worse, it denies females from ever becoming entrepreneurs due to the lack of knowledge and experience in addition to discrimination and culture (Crals \& Vereeck, 2005; Aljuwaiber, 2020).

According the World Bank the adult female literacy rate has increased from $22 \%$ in the late 1970 s to $65 \%$ by 2018 . The improvement in female educational levels is significant. However, only $67 \%$ of those females finished their secondary education as literacy rate can be 
increased even if primary and preparatory school has been finished. This problem in Egypt is created by many factors, including early marriage where females only finish some of their education but then stop in order to get married and become housewives (Kirby \& Ibrahim, 2011). Considering all this and the fact that in order for females to get decent jobs and increase their entrepreneurial chances they need to at least finish their secondary education. That is why the factor that affects female educational qualification the most is whether they get to finish their secondary education or not. If they do, the chances a female has in getting a higher education and decent work increases and that is why secondary education is considered a factor that determines the educational chances of females (Assaad, Krafft \& Yassin, 2020). After that comes the female economic opportunities, due to many factors mostly mentioned earlier, the female economic opportunities were very low in Egypt. Although the government has been working hard to improve the women's stance, increase their opportunities and protect them by more laws. The level of economic opportunities is significantly low compared to other countries but it is also higher than most African and neighbouring countries (Mahrous, 2019). Also, savings and investment are two very important factors in the sustainability of the economy as those factors help create new business chances and motivates entrepreneurship and innovation with the ease of financing and the chance to build a business through investing the savings in new businesses and small and medium enterprises (SMEs) that has a huge effect on the economic development and growth in Egypt. The increased level of savings, investments and the new businesses increase the job opportunities in Egypt to both males and females which help both genders in finding new job and creating new entrepreneurial chances (Crals \& Vereeck, 2005). Those chances are created for both males and females as digitalization has a huge deal to do with globalization which calls for equality and equal chances for both genders which is considered a chance for females (Dahshan, Tolba \& Badreldin, 2012). Hence, the digitalization movement has supported entrepreneurship worldwide and in Egypt as well as entrepreneurs has benefited from the new ICTs and technologies in addition to the new financial inclusion products that helped with the financing of businesses and helped entrepreneurs grow and sustain their SMEs and businesses and helped them plan a brighter future to it (Lyons \& Contreras, 2017).

\section{Model specification and data}

Scientific literature on the topic distinguish variables that affect female entrepreneurship in Egypt. Indicators can be received as education, economic opportunities, technology, saving and financial inclusion. The research model is represented in the below Figure 1.

Figure 1. Research model

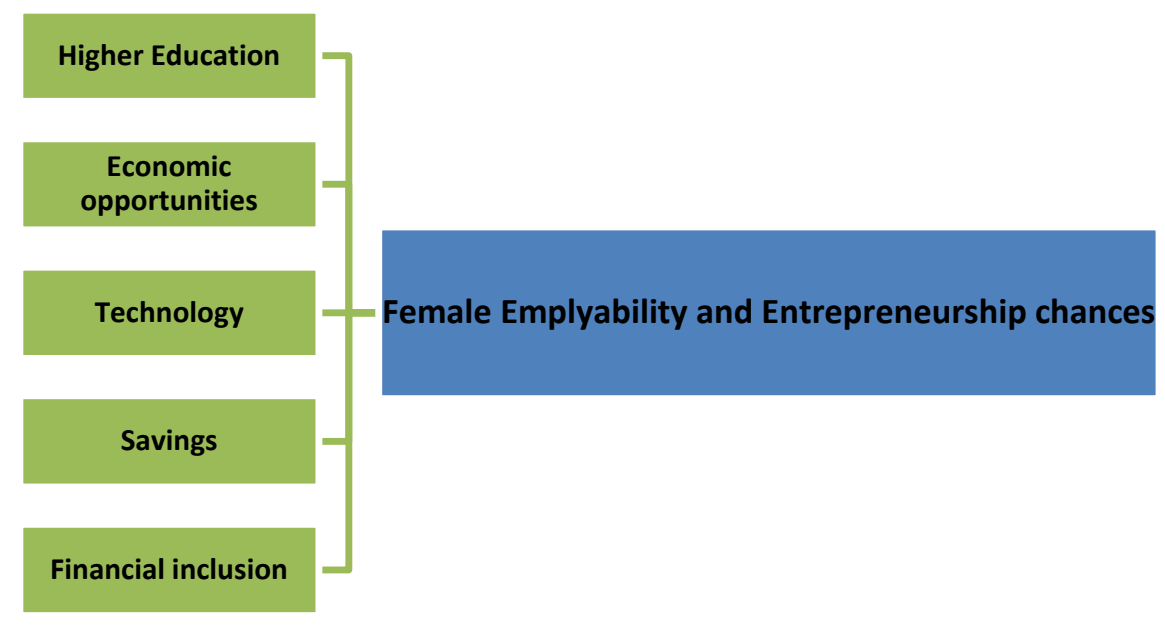


Source: author's collaboration

\subsection{Research Hypothesis}

H1 - Higher education increases the female employability chances.

H2 - The female economic opportunities in Egypt has a direct relation with entrepreneurship chances of females in Egypt.

H3 - The level of technology and the countries use of technology creates more job opportunities which increases the female employability level.

H4 - The gross savings increases the female investment and entrepreneurship chances in Egypt.

H5 - Financial inclusion helps females in gaining better entrepreneurship chances.

\section{Data \& variables}

This paper uses secondary data that is obtained from the world bank covering the period from 1991 till 2019 with data that represents every variable in order to be tested on the dependent variable in order to determine the relation and how every independent variable affect the dependent variable which is female entrepreneurship and employability. The statistics depends on a time series data as it analyses the same thing over a period of time with equal time intervals. The research is built on secondary data and all secondary data are taken and collected from previous research data and all are from the World Bank indicators. The research and analysis tackle five main factors that could affect the dependent variable. Those variables are education, technology, savings, economic opportunities and financial inclusion. All these factors help the female be more qualified and gives her a better chance in the real world but do they actually affect the dependent variable?

\subsection{Dependent Variables: Female Entrepreneurship in Egypt (FEMP)}

Female entrepreneurship is an essential factor for a more sustainable economic growth worldwide. With the world targeting a more equal and fair world females were given a chance to gain their rights and being taken seriously in the business environment after years of oppression by the male dominated society. However, after years of suppressed rights and very little gains the number of female entrepreneurs has decreased and the number of females qualified to become entrepreneurs has decreased as well. And in order to increase the number of female entrepreneurs, some factors were needed to be considered which included the level of education, technology, financial inclusion, savings and economic opportunities. All the previous factors were claimed to have an effect on female entrepreneurship and could help increase it.

Figure 2. Employers, female during 2005 till 2019

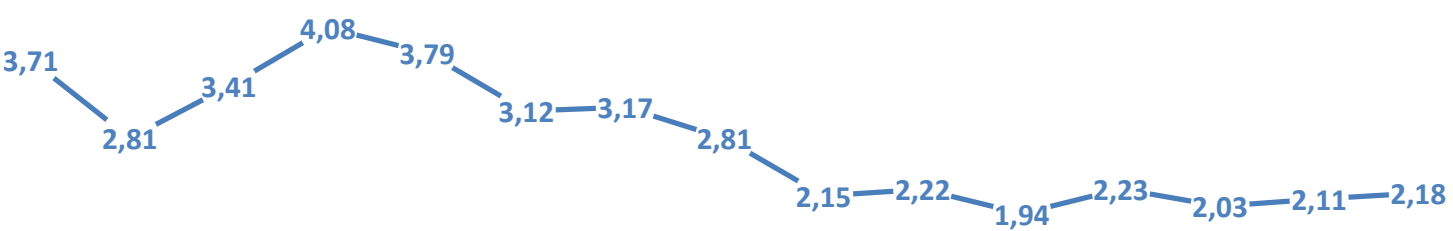

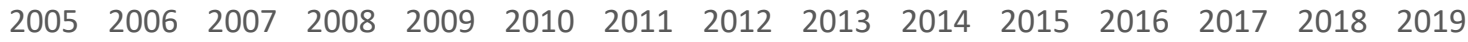

Source: https://www.worldbank.org/ 
In order to represent the female entrepreneurship, this indicator was chosen as it calculates the percentage of female employers as a percentage from the total female labour force in Egypt which indicate entrepreneurship. According to Figure 2, the percentage of female employers in Egypt has decreased ever since 2011 after the political instabilities. However, it started increasing in the past few years. As this indicator is used to determine how the changes in other factors affect the level of female entrepreneurship it also must be noted that there are other factors such as the economic and political instabilities in the country that affected the level of investments and lowered the female chances at a time.

\subsection{Independent Variables: Female Higher Education (EDU)}

In this paper, the percentage of females has been used in secondary schools as according to the world bank, most females who are enrolled in schools only get to finish their primary education and most females don't even get a chance to enrol in secondary education better yet a university or a bachelor degree. Having at least a secondary education increases the female chances in enrolling for a bachelor degree or finding a job that only requires a secondary education. This multiplies their chances and that is why this indicator was selected for analysis of the educational factor and its effect on the female employability and entrepreneurship in Egypt. According to Figure 3, the percentage of females in secondary schools is almost constant with $48 \%$ over the years. This, percentage has improved over the years, but using our time interval it is almost constant with very minor fluctuations (Vakili, Tahmasebi, Tahmasebi \& Tahmasebi, 2016).

Figure 3. Secondary education, pupils (\% female) during 2005 till 2019

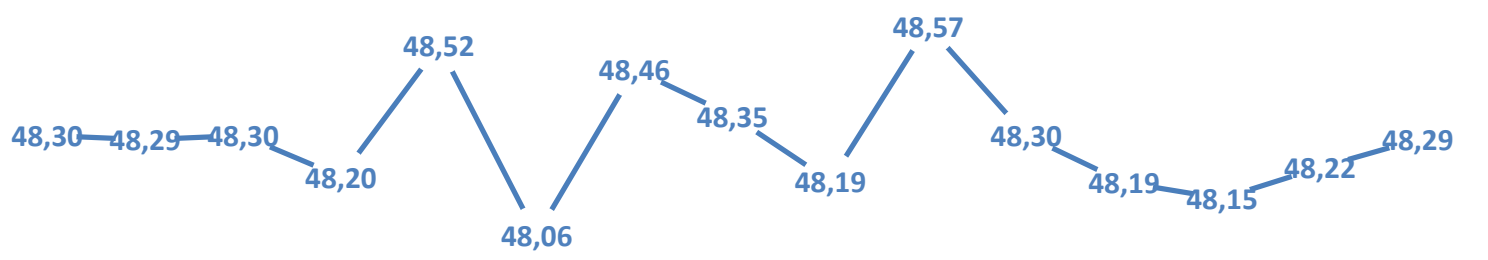

$20052006200720082009201020112012 \quad 2013 \quad 2014 \quad 20152016201720182019$

Source: https://www.worldbank.org/

\subsection{Economic opportunities: Women business and law index score (LAW)}

In many developing countries the women have fewer economic opportunities than men as the cultural and traditional aspects restrict the female and make her have fewer opportunities than males. Males in the Egyptian culture are empowered to go places, get a better education and have more chances of getting better jobs and being an influencing part of the community. The women in business and law index is an indicator that measures how laws and regulations affect women's economic opportunity. Overall scores are calculated by taking the average score of each of the eight areas (Going Places, starting a job, getting paid, getting married, having children, running a Business, managing assets and getting a pension), this score is then calculated with a highest score of 100 to determine the female economic opportunities in a country. 
Figure 4. Women Business and the Legislation Index during 2005 till 2019

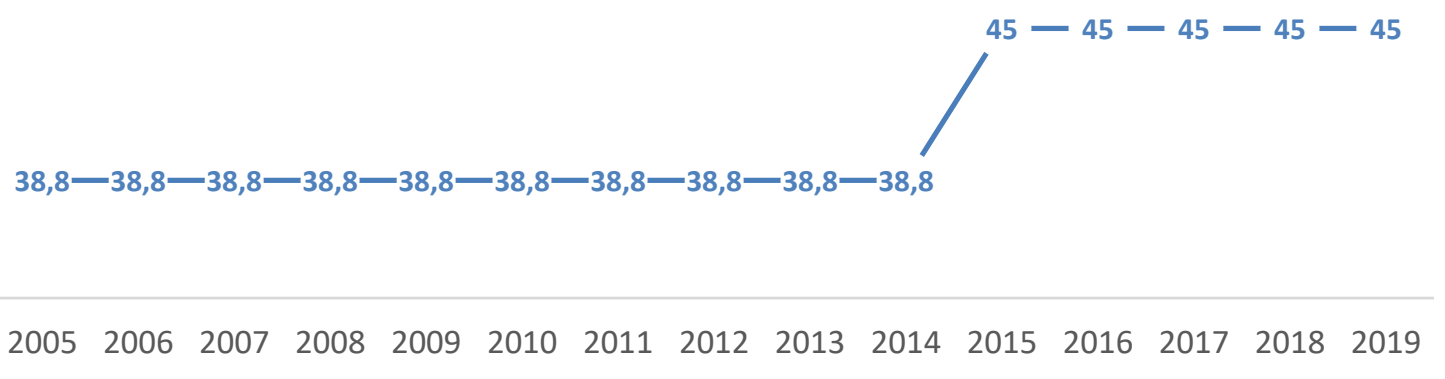

Source: https://www.worldbank.org/

This indicator is chosen in this paper as it describes the female business and legislations and how the culture, rules and regulations affect their economic opportunities and chances. Also, it shows that even if the females are excluded from the education violation and they do gain their education, their restricted by the low economic opportunities they face. Considering that, the Egyptian culture dictates that even the females that have better chances should be protected from the community and must face the cultural restrictions that they don't get to experience half the opportunities that males are subjected to under the umbrella of protecting the females. The restrictions that females are subjected to limits their economic opportunities and lowers the score of the eight areas that the indicator covers which limits their chances in the Egyptian job market and make them not be taken seriously due to the male dominated environment (Zuhur, 2001). According to Figure 4, the women business and legislation in Egypt has improved over the years and ended up increasing which indicates how the laws and community is being more acceptable to female rights and they started obtaining their rights which led to a higher score over the years. But even with the indicator increasing its still below 50 which indicates a low level of economic opportunities for women in Egypt. This indicator will be used to analyse its effect on female entrepreneurship and employability as a factor that indicates economic opportunities.

\subsection{Level of technology: \% of ICT imported}

The digital era is expanding in many fields in the Egyptian and global community. However, for this paper there is a main branch of digitalization that is essential to the business environment that is why the Information and communications technologies (ICTs) are selected. The ICT industry creates the data bases and the new technologies that are used in businesses which include, customers and employee's data bases, and creating the platforms that employees use to communicate and manage their work (Nambisan, Wright \& Feldman, 2019).

Figure 5. ICT goods imports during 2005 till 2019

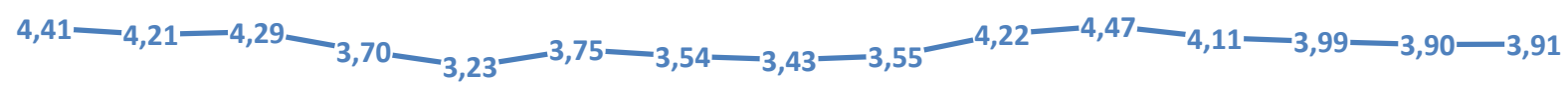

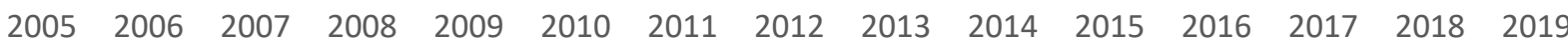

Source: https://www.worldbank.org/

ICTs had become one of the most important and wide technological aspects that keeps on growing worldwide with new innovations each and every day. The widespread of ICTs and the more people familiarizing themselves with it creates a more stable work environment and 
a more sustainable digital era which helps in creating many new jobs, economic and entrepreneurial opportunities for the entire community. This will open a new path for female entrepreneurs and will create more job opportunities especially for people with any technological knowledge as this has become one of the most important qualifications in our world today (Rizk \& Kamel, 2013).

The indicator chosen to represent the ICT growth in the Egyptian community and businesses has been the percentage of Information and communication technologies imported as a percentage of total imports. The information and communication technologies imported include computers, communication equipment, and consumer electronic equipment. These imported goods stabilize the digitalisation more and indicates how much the ICT use is growing and how ICTs are a common commodity that is demanded and required by the community. Not just that, but this indicator is used to describe the technological factor that affects the female entrepreneurship and employability chances in Egypt among other factors (Badran, 2010). According to Figure 5, this indicator has fluctuated over the years between 4.5 and $3 \%$ which means that between $4.5 \%$ and $3 \%$ of Egyptian imports are ICTs goods which are used to improve the digitalization in Egypt. The imported ICTs goods will be used to see its effect on female chances in Egypt.

\subsection{Savings: Gross Savings (\% of GNI) (SAV)}

As the main focus of the paper is female employment and entrepreneurial activities in Egypt. One of the main factors that affect investment and entrepreneurship are savings as savings has a positive relation with investment and as savings increase investments. When investment chances increase because of savings it creates a wide path to entrepreneurship which females will benefit from and will help them create their own new business chances (Tee, 1987).

Figure 6. Gross savings (\% of GNI) during 2005 till 2019

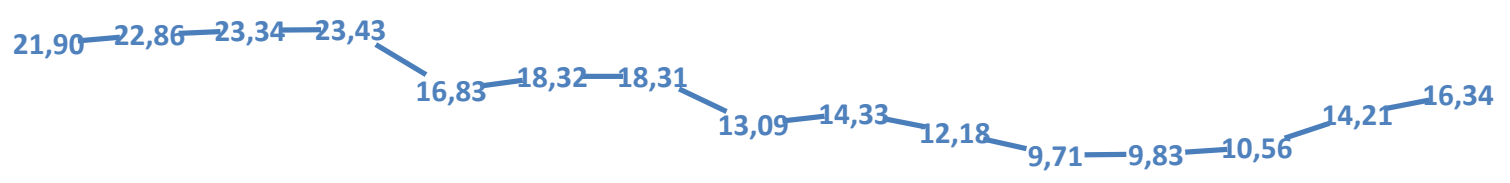

$200520062007200820092010 \quad 2011 \quad 2012 \quad 2013 \quad 2014 \quad 2015 \quad 2016 \quad 2017 \quad 20182019$

Source: https://www.worldbank.org/

Figure 6 show the gross savings in Egypt has fluctuated over the years a noticed a major drop in past years starting from 2011 after the political imbalances that happened in the country. However, gross savings has been increasing over the past few years starting from 2016 to go from $9.8 \%$ of GNI in 2016 to reach $16.3 \%$ of GNI in 2019 this indicates new investment opportunities which female entrepreneurs should benefit from.

\subsection{Financial inclusion (FIN)}

Concerning ownership at a financial, female (\% of population ages $15+)$. Financial inclusion is the process of providing financial products with all its kinds and make it accessible, useable, affordable and available to all the population of the country. After countries led by India has achieved major successes with financial inclusion and were able to innovate new technologies that fulfils the needs of the population it created a major movement that supports the moving towards financial inclusion (Lyons \& Contreras, 2017). 
After the spread of financial technologies females and the Egyptian population became more aware of the importance of the financial market which increased the financial literacy in the country. This indicator was chosen as it shows how financial inclusion is increasing in Egypt between females and how their responding to the financial literacy move (Fareed, Gabriel, Lenain \& Reynaud, 2017). According to Figure 5, show the effect of the increase of ATM machines in an increasing trend, see Figure 7a.

Figure 7a. Automated teller machines (ATMs) (per 100,000 adults) during 2004 till 2019

$$
2,6-3,3-4,4-5,4-6,5-7,7-8,6-9,2-10,3=10,9 \cdot 12,1=13,7=15,7=17,7=18,7=20,1
$$

\section{9}

Source: https://www.worldbank.org/

The available data is not limited thus another variable is recommended which represent the individual using internet as it is available since 1994 and it is increasing as explained in the following Figure $7 b$.

Figure 7b. Individuals using the Internet (\% of population) during 2000 till 2019

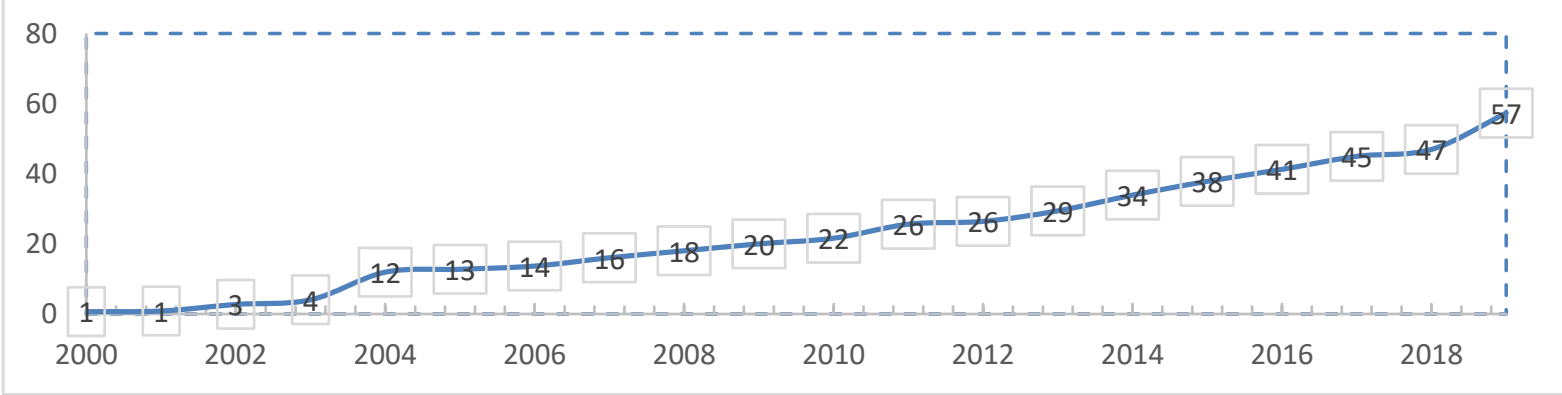

Source: https://www.worldbank.org/

After viewing the model variables which shows the maximum and minimum value for the independent variables during the period under study which reflects the small difference between them, as seen in the following Table 1.

Table 1. Descriptive statistics

\begin{tabular}{l|r|r|r|r|r|r}
\hline & \multicolumn{1}{l}{ FEMP } & \multicolumn{1}{l}{ LDU } & \multicolumn{1}{l}{ ICT } & \multicolumn{1}{l}{ SAV } \\
\hline Mean & 3.872821 & 46.83734 & 37.20714 & 2.716969 & 19.47451 & 14.60982 \\
\hline Median & 3.9935 & 46.8 & 38.8 & 3.625276 & 18.69728 & 12.335 \\
\hline Maximum & 6.491 & 48.56597 & 45 & 5.039085 & 35.29576 & 46.92434 \\
\hline Minimum & 1.944 & 43.23911 & 32.5 & 0 & 9.71221 & 0.000579 \\
\hline Std. Dev. & 1.306728 & 1.41469 & 4.303739 & 1.943329 & 6.507686 & 15.76118 \\
\hline Skewness & 0.172505 & -0.78464 & 0.421205 & -0.63714 & 0.820924 & 0.684903 \\
\hline Kurtosis & 2.103183 & 2.878924 & 2.211337 & 1.580577 & 3.605051 & 2.155935 \\
\hline Jarque-Bera & 1.077197 & 2.890207 & 1.553585 & 4.245001 & 3.572045 & 3.020287 \\
\hline
\end{tabular}

Source: author's collaboration 


\subsection{Econometric Model}

The analysis and techniques that will be used in this research is the regression model which indicates the relation and the coefficients of each of the selected variables using a quantitative method in order to be able to analyse the data obtained and check for the vitality of the hypotheses proposed. The variables set and the hypotheses of the model the economic model of the research was set to be that female entrepreneurship is determined by factors including the five factors of the model which are education (EDU), economic opportunities (LAW), technology (ICT), savings (SAV) and financial inclusion (FIN) . Which means that the economic model is as follows.

\section{Female Entrepreneurship $(F E M P)=\mathcal{F}(E D U, L A W, I C T, S A V, F I N)$}

Which indicates that female entrepreneurship (F-EMP) is a function of the five independent variables stated by the model, and the hypothesis suggests and assumes that there's a positive relation between all of the independent factors and the dependent female entrepreneurship.

The econometric model is used to derive and analyse the economic relations assumed by the hypothesis in order to conduct a quantitative analysis to determine the actual relations of the model in order to prove or reject the hypothesis claimed and to determine the relations of the economic model. The interception coefficient which indicates any other factors affecting entrepreneurship is $(\alpha)$. The coefficient of Education $\left(\beta_{1}\right)$. The coefficient of Economic opportunities $\left(\beta_{2}\right)$. The coefficient of Technology $\left(\beta_{3}\right)$. The coefficient of Savings $\left(\beta_{4}\right)$. The coefficient of Financial Inclusion $\left(\beta_{5}\right)$. And $(\mathrm{E})$ is Random error term.

$$
F E M P=\alpha+\beta_{1} E D U_{1 t}+\beta_{2} L A W_{2 t}+\beta_{3} I C T_{3 t}+\beta_{4} S_{4 t}+\beta_{5} F I N_{5 t}+\varepsilon
$$

\subsection{Empirical Results}

In the model assessment after interpreting the parameters and estimating the econometric model further analysis is required in order to determine the significance of the model and the multicollinearity and more indications that shows the importance and vitality of our model. In this section stationarity test, correlation test and ARDL test have been conducted.

\subsubsection{Stationary test}

Applying the Augmented Dickey Fuller test (ADF) and Phillips-Perron (PP) stationary test showed that all the majority of independent variable are non-stationary in level at constant and trend except education, saving and financial inclusion. While PP test it supports the ADF test as all the results showed a stationarity at the first difference, except Financial inclusion which is stationary at the second difference, see Table 2.

Table 2. Stationary test-Augmented Dickey fuller (ADF) and Phillips-Perron (PP)

\begin{tabular}{|c|c|c|c|c|c|c|c|c|}
\hline \multirow{3}{*}{ Variables } & \multicolumn{4}{|c|}{ ADF } & \multicolumn{4}{|c|}{ PP } \\
\hline & \multicolumn{2}{|c|}{ level } & \multicolumn{2}{|c|}{ 1st diff } & \multicolumn{2}{|c|}{ level } & \multicolumn{2}{|c|}{ 1st diff } \\
\hline & constant & trend & constant & trend & constant & trend & constant & trend \\
\hline FEMP & -0.7837 & - $3.35182 *$ & $-\overline{5.96548 * * *}$ & $6.21694 * * *$ & -1.17021 & -2.97839 & $\overline{7}-27605 * * *$ & - $11.4173 * * *$ \\
\hline EDU & - $2.9447 *$ & -2.83422 & $\begin{array}{l}- \\
7.31236 * * *\end{array}$ & $\begin{array}{l}- \\
7.83269 * * *\end{array}$ & - $3.06285^{*}$ & -2.68713 & $\overline{7.43963 * * *}$ & $-9.1085 * * *$ \\
\hline Law & -0.3101 & -2.53108 & $-\overline{5.58515^{* * *}}$ & $\begin{array}{l}- \\
5.54347 * * *\end{array}$ & -0.26479 & -2.55474 & $\begin{array}{l}- \\
5.58466 * * *\end{array}$ & $\begin{array}{l}5.54347 * * * \\
\end{array}$ \\
\hline
\end{tabular}




\begin{tabular}{|c|c|c|c|c|c|c|c|c|}
\hline FIN & 3.71219 & -0.26587 & $-2.70013^{*}$ & $\overline{-} \overline{5.07621 * * *}$ & 4.888465 & 0.669303 & $-2.38491^{*}$ & $\begin{array}{l}- \\
5.21779 * * *\end{array}$ \\
\hline Sav & - $2.6321 *$ & -2.82198 & -3.56878 & -4.09946 & -2.58324 & -1.88763 & $-3.56878 *$ & $-4.11497^{*}$ \\
\hline ICT & -1.3339 & -2.0139 & $\begin{array}{l}- \\
4.74264 * * *\end{array}$ & $-4.6457 * * *$ & -1.31101 & -2.01359 & -4.72694 & -4.61329 \\
\hline
\end{tabular}

Source: author's collaboration

Note: $*$ is significant at $90 \%, * * *$ significant at $99 \%$

In case of having variables that record different order of integration application of Engel Granger and Johansen techniques is ruled out as both techniques require variables of same order of integration. In case variables have I (0) and I (1) order of integration and no variable of order I (2) the appropriate choice left is to use Autoregressive Distributive Lag (ARDL) model. To apply ARDL model than it is required to determine the lag, thus we use Unrestricted VAR model. Thus, using Akaike information criterion (AIC) optimum lag length 3 was selected (see Table 3).

Table 3. VAR Lag length Selection Criteria

Endogenous Variables : FEMP, SAV, EDU, LAW, FIN ICT

\begin{tabular}{r|l|l|l|l|l|l}
\hline Lag & LogL & LR & FPE & AIC & SC & HQ \\
\hline $\mathbf{0}$ & -297.584 & NA & 1421.817 & 24.2867 & 24.57923 & 24.36783 \\
\hline $\mathbf{1}$ & -183.074 & 164.8946 & 2.917738 & 18.00589 & 20.0536 & 18.57383 \\
\hline $\mathbf{2}$ & -133.31 & 47.77304 & 1.73953 & 16.9048 & 20.70769 & 17.95956 \\
\hline $\mathbf{3}$ & 37.19502 & $1.84241^{*}$ & $.000320^{*}$ & $6.144398 *$ & $1.70247 *$ & $7.685972 *$ \\
\hline
\end{tabular}

Source: author's collaboration

The bound tests has been applied, because it does not depend of pretesting the order of cointegration of the variables and it eliminates the uncertainty of pre-testing the order of integration of the variables. Also, the bound test approach is privileged because it can be applied to a small sample size which is the case in the current study.

After determine the lag length which is determined by AIC, then the next step, to check whether variables are associated in the long run to each other, Bounds test is performed on the following model.

Table 4. ARDL Bounds Test

\begin{tabular}{|c|c|c|c|c|c|c|c|}
\hline $\mathrm{K}$ & $\mathrm{F}$ & Critical Value Bounds & \multicolumn{2}{|c|}{$10 \%$} & $5 \%$ & \multicolumn{2}{|c|}{$2.50 \%$} \\
\hline 5 & 77.42401 & I0 Bound & 2.26 & 2.62 & & 2.96 & 3.41 \\
\hline & & I1 Bound & 3.35 & 3.79 & & 4.18 & 4.68 \\
\hline
\end{tabular}

Source: author's collaboration

The results show that the computed f-statistic equal 77.424 which more than the upper bound critical value at $1 \%$ level of significance; hence, the null hypothesis was rejected, confirming the existence of co-integration among the variables series in the model. The existence of co-integration supports the long-run relationship of the factors that affected Female as employer. Based on the result of the existence of cointegration ARDL to estimates the long run elasticities using the following specification has been applied:

$$
\begin{aligned}
\text { FEMP }=\alpha_{0} & +\alpha_{1} F E M P_{t-1}+\alpha_{2} E D U_{1 t-1}+\alpha_{3} L A W_{2 t-1}+\alpha_{4} I C T_{3 t-1}+\alpha_{5} S_{a v_{4 t-1}} \\
& +\alpha_{6} \text { FIN }_{5 t-1}+\varepsilon
\end{aligned}
$$


The model selection criteria, such as Akaike info. Criterion ACI, Hannan-Quinn HQ, and Adjusted R-squared used. ARDL (1, 3, 3, 3, 3, 3) model has been established as the best model for the series.

\subsubsection{Long Run Estimates}

Results of long run model are presented in Table 5. The lag selection in the empirical model is based on general to specific methodology of lag selection (Pesaran et al., 2001).

Table 5. ARDL long run relation

\begin{tabular}{|c|c|c|c|c|}
\hline \multicolumn{5}{|c|}{ Dependent variables: FEMP } \\
\hline Variable & Coefficient & Std. Error & t-Statistic & Prob.* \\
\hline$Y(-1)$ & $0.862619 * *$ & 0.105237 & 8.196902 & 0.0038 \\
\hline EDU & $0.730243 * *$ & 0.063294 & 11.53726 & 0.0014 \\
\hline EDU (-1) & $-0.53443^{* *}$ & 0.06816 & -7.840754 & 0.0043 \\
\hline EDU $(-2)$ & $-0.27703^{*}$ & 0.084278 & -3.287054 & 0.0462 \\
\hline EDU $(-3)$ & $0.323901 *$ & 0.085364 & 3.794346 & 0.0321 \\
\hline LAW & $0.127209 *$ & 0.037814 & 3.364101 & 0.0436 \\
\hline LAW (-1) & -0.1281 & 0.039819 & -3.217113 & 0.1487 \\
\hline LAW(-2) & -0.01753 & 0.042142 & -0.415934 & 0.7054 \\
\hline LAW (-3) & 0.05904 & 0.028283 & 2.08746 & 0.1281 \\
\hline ICT & $-0.34266 * *$ & 0.04097 & -8.363673 & 0.0036 \\
\hline $\operatorname{ICT}(-1)$ & $0.580202 * *$ & 0.053811 & 10.78226 & 0.0017 \\
\hline $\operatorname{ICT}(-2)$ & $-0.55377 * *$ & 0.076924 & -7.198977 & 0.0055 \\
\hline $\operatorname{ICT}(-3)$ & $-0.39196 * *$ & 0.056364 & -6.954073 & 0.0061 \\
\hline SAV & $0.253543 * *$ & 0.025159 & 10.0777 & 0.0021 \\
\hline SAV (-1) & $-0.08239 *$ & 0.014799 & -5.567421 & 0.0114 \\
\hline $\operatorname{SAV}(-2)$ & $0.101236^{*}$ & 0.019312 & 5.242153 & 0.0135 \\
\hline SAV (-3) & $-0.07151^{*}$ & 0.012631 & -5.661622 & 0.0109 \\
\hline NET & $0.172483 * *$ & 0.028777 & 5.99372 & 0.0093 \\
\hline NET (-1) & 0.037044 & 0.031462 & 1.177436 & 0.3239 \\
\hline NET (-2) & $-0.36113^{*}$ & 0.028937 & -12.47977 & 0.0011 \\
\hline NET (-3) & $0.213679 *$ & 0.03062 & 6.978382 & 0.006 \\
\hline $\mathrm{C}$ & -15.2682 & 8.457785 & -1.805226 & 0.1688 \\
\hline Diagnostic test & & \multicolumn{2}{|c|}{ Sum squared resid } & 0.028662 \\
\hline R-squared & 0.999376 & \multicolumn{2}{|l|}{ F-statistic } & 228.9373 \\
\hline Adjusted R-squared & 0.995011 & \multicolumn{2}{|c|}{ Prob(F-statistic) } & 0.000411 \\
\hline S.E. of regression & 0.097745 & & & \\
\hline
\end{tabular}

Source: author's collaboration

Results shows that coefficients of all independent variables are significant except law, however, the coefficient has negative sign with female employer but not significant. Education, saving and ICTs sign changes across lag time with FEMP. The coefficient of Education $(0.7320)$ is highly significant but the sign in lag 2 and 3 is negative in lag 2 and 3 which can be explained that education is still in need to be linked with job opportunities. As at the beginning it reflects positively but not lasting. ICTs have appropriate positive sign (0.580202) and are significant at 5\% level of significance, however the sign varies across lags. SAV shows positive relationship with FEMP and is significant but in lag 3 the sign changes which can be explained by the changes in the price level that have direct effect on the saving. Finally, internet shows a highly significant impact on lag 3 with FEMP and the sign is positive. The impact of internet to accelerate female employability takes time to have a positive effect which the case in many developing countries as they need many initiatives to foster employability. The value of Adjusted $\mathrm{R}^{2}(0.9947)$ indicates that $99 \%$ variation in FEMP is explained by explanatory variables in model and F-Statistics is also significant at $1 \%$ significance level indicating that all independent variables in the model jointly affect FEMP. 
Table 5 shows the results of long-run test, results indicates that most of the long-run coefficients are significant (at or under 5\%), in explaining the dependent variable, information communication technology variable was significant at $10 \%$. However, rest of variables are insignificant. Following the estimation of long-run coefficients, the error correction model (ECM) based on the ARDL model was formed to estimate the short-run coefficients. Examine serial correlation, Heteroskedasticity, model specification, model stability and normality were applied to ensure nonexistence of econometric problems.

Table 6. Heteroskedasticity Test

Heteroskedasticity Test: Breusch-Pagan-Godfrey

\begin{tabular}{llll}
\hline F-statistic & 0.639538 & Prob. F $(8,17)$ & 0.7347 \\
\hline Obs*R-squared & 6.014747 & Prob. Chi-Square (8) & 0.6456 \\
\hline Scaled explained SS & 2.921097 & Prob. Chi-Square (8) & 0.9392 \\
\hline
\end{tabular}

Source: author's collaboration

To check residuals for Heteroskedasticity Breusch Pegan Godfrey test is applied. Null hypotheses of no Heteroskedasticity were rejected as probability of F-statistics and Obs*Rsquared are more than 0.05 suggesting that residuals have no problem of Heteroskedasticity.

\section{Results}

The whole regression model was proved to be significant with the variables. However, after conducting the ARDL test on the parameters to analyse their significance it was shown that four of the five picked parameters for the research were proved to be significant to the model. And only the Law independent variable was proved to be significant to the model. Which means that the savings coefficient has a positive significant relationship with the female entrepreneurship in Egypt and as the savings increase with $1 \%$ according to the results in lag 2 it increases female employability by $10 \%$, a state that provide more chances for female entrepreneurship. The results of the study reflect the current situation of the urgent need to foster female opportunity in the digital era. The insignificant of law index on female employability emphasis of the continuity of depriving move of participation in the market as still many barriers are valid and limit its participation. Also, the sign of the regressors that changes showed the unstainable impact of the changes in the independent variables on the female employability.

The limitations of this study were achieving sustainable data that would help the parameters become more significant. The indicators picked were representative to the variables but, they were not representing enough even when the model was proved to be significant with a coefficient of determination. Also, there are many more factors that affect the female entrepreneurship and employability chances not accounted in the model. However, most of the other factors has to do with the cultural beliefs and the traditional influence which couldn't be quantified to be represented in the model. Females in Egypt have a brighter future than they ever had with all the new variables that keep on changing each and every single day.

\section{Conclusion and Policy recommendation}

Female entrepreneurship in Egypt faces many challenges and it would remain a challenge until the cultural beliefs and the peoples' mentalities are more accepting to the new era the world is entering were equality is called for and women have to be treated as a significant part of the community. In order to achieve a more sustainable technological growth and the sustainable development goals which if achieved will boost our world and help create more and more chances for the female entrepreneurship and employability and won't be achieved otherwise. But In the meantime, the government should focus on making education 
mandatory for males and females in order to have a new generation that is educated and accepting to the new variables of the world. The Egyptian government is focusing on spreading equality in the meantime which is helping the females gain more grounds. And with the move towards achieving the SDGs the government and people are focusing on improving digitalization, financial inclusion and promoting equality as well by supporting SMEs and new businesses in order to boost the economy which gives females a stronger chance than ever but they have to be able to utilize this chance in order to be able to make a better future out of it (Bary, 2019). The digital era seeks qualification and with the world globalization stronger than ever, more job opportunities for females keep on presenting themselves especially with Multinational cooperation (MNCs) that try to promote and obey the new rules of equality. All of those factors promote female employability, and as employability increase, female entrepreneurial chances increase with it which creates more job opportunities and keeps on promoting the female's role in the community even in a male dominated environment such as Egypt (Dahshan, Tolba \& Badreldin, 2012).

Also, utilizing the female labour force is one of the most important factors that will promote a better economy and help Egypt in its' take off stage and could be one of the most significant factors in helping Egypt boost its development in the upcoming years. Going back to the model, the multiple regression model showed a positive relationship between most of the variables and female entrepreneurship which was already proved and anticipated from the literature and theories. However, the positive relation was proven without the significance of the variables. This insignificance could be accounted for by many things which could include a problem with the model or data itself. But this doesn't change that those factors could help promote female entrepreneurship and employability in Egypt and none of the factors discussed in the model should be overlooked as all those factors will help Egypt achieve a better future. Even if the parameters and factors are insignificant to the female entrepreneurship in Egypt, they're still significant in improving the female chances in the business world and in their employability chances and would be a key element in improving the Egyptian business environment overall. 


\section{References}

Aljuwaiber, A. (2020). Entrepreneurship research in the Middle East and North Africa: trends, challenges, and sustainability issues. Journal of Entrepreneurship in Emerging Economies, https://doi.org/10.1108/JEEE-08-2019-0123

Assaad, R., Krafft, C., \& Yassin, S. (2020). Job creation or labor absorption? An analysis of private sector job growth in Egypt. Middle East Development Journal, 12(2), 177207. https://doi.org/10.1080/17938120.2020.1753978

Badran, M. F. (2010). Is ICT empowering women in Egypt? An empirical study. In Proceedings of the Research Voices from Africa Workshop, IFIP WG (Vol. 9). Retrieved from https://www.mak.ac.ug/documents/IFIP/EMPOWERINGWOMENINEGYPT.pdf

Bary, A. (2019). SMEs Sector: A Key Driver to the Egyptian Economic Development. https://dx.doi.org/10.2139/ssrn.3334845

Crals, E., \& Vereeck, L. (2005). The affordability of sustainable entrepreneurship certification for SMEs. The International Journal of Sustainable Development \& World Ecology, 12(2),173-183. https://doi.org/10.1080/13504500509469628.

Dahshan, M. E., Tolba, A. H., \& Badreldin, T. (2012). Enabling entrepreneurship in Egypt: Toward a sustainable dynamic model. Innovations: Technology, Governance, Globalization, 7(2), 83-106. Retrieved from https://ideas.repec.org/a/tpr/inntgg/v7y2012i2p83-106.html

Fareed, F., Gabriel, M., Lenain, P., \& Reynaud, J. (2017). Financial Inclusion and Women Entrepreneurship: Evidence from Mexico. OECD Economics Department Working Papers No. 1411. https://doi.org/10.1787/18151973

Kirby, D. A., \& Ibrahim, N. (2011). Entrepreneurship education and the creation of an enterprise culture: Provisional results from an experiment in Egypt. International Entrepreneurship and Management Journal, 7(2), 181-193. https://doi.org/10.1007/s11365-010-0153-0

Lyons, A., \& Contreras, S. (2017). A simultaneous model of youth entrepreneurship and financial inclusion across developing countries. SSRN. http://dx.doi.org/10.2139/ssrn.3053615

Mahrous, A., A. (2019). Female entrepreneurship in Egypt: new theoretical and public policy implications. Marketing and Management of Innovations, 1, 151-160. http://doi.org/10.21272/mmi.2019.1-12

Nambisan, S., Wright, M., \& Feldman, M. (2019). The digital transformation of innovation and entrepreneurship: Progress, challenges and key themes. Research Policy, 48(8), https://doi.org/10.1016/j.respol.2019.03.018

Quadrini, V. (2009). Entrepreneurship in macroeconomics. Annals of Finance, 5(3), 295-311. DOI: $10.1007 / \mathrm{s} 10436-008-0105-7$ 
Rizk, N., \& Kamel, S. (2013). ICT and building a knowledge-based society in Egypt. International Journal of Knowledge Management (IJKM), 9(1), 1-20. DOI: $10.4018 / \mathrm{jkm} .2013010101$

Russell, M. L. (1992). The Female Brain Drain, the State and Development in Egypt. Journal of Developing Societies, 8(1), 122. Retrieved from https://www.africabib.org/rec.php?RID=W00093520\&DB=w

Shammas, C. (1994). Re-assessing the married women's property acts. Journal of Women's History, 6(1), 9-30. Retrieved from http://courses.knox.edu/hist267/shammasproperty.pdf

Shann, M. H. (1992). The reform of higher education in Egypt. Higher Education, 24(2), 225-246. https://doi.org/10.1007/BF00129443

Tee, K. A. (1987). Saving, investment and entrepreneurship. The Singapore Economy Reconsidered, 73, 78.

Tucker, J. (1976). Egyptian women in the work force: An historical survey. MERIP Reports, (50), 3-26. https://doi.org/10.2307/3010883.

Vakili, F., Tahmasebi, N., Tahmasebi, S., \& Tahmasebi, D. (2016). Role of education in entrepreneurship development. Journal of Ecophysiology and Occupational Health, 16(3/4). DOI:10.15512/joeoh/2016/v16i3\&4/16046

World Bank (2019). International Economics Dept. Development Data Group. World development indicators. Retrieved from https://www.worldbank.org/

Zuhur, S. (2001). The mixed impact of feminist struggles in Egypt during the 1990s. Middle East Review of International Affairs, 5(1), 78-89. Retrieved from http://www.rubincenter.org/meria/2001/03/zuhur.pdf 


\title{
THE IMPACT OF OTA - TRANSFORMING CONTEMPORARY TOURISTS' INTENTIONS
}

\section{IVAYLO IVANOV ${ }^{1}$}

\begin{abstract}
Modern hotel bookers claim to switch moods to the digital distribution model of hospitality services. A survey conducted in Bulgaria among frequent travellers reveal their attitudes when making a hotel room reservation. Taking into account the implementation of contemporary digital technologies in everyday life this article is observing the main distribution channels that are used in hotel industry. Compared are the preferences of the different age groups using a questionnaire distributed among them. Online Travel Agencies (OTA) platforms and hotels both compete and collaborate to attract customers in the worldwide web. The results of the survey reveal an ongoing process of digitalization even in sectors highly dependent on human capital. The need for remodelling market strategies of travel companies and adjusting their business performance while taking into account the trends and expectations of consumers is visible. Digitalization of the hotel reservation process in Bulgaria and the domination of Booking.com as a leading OTA confirms the fact that the domestic hotel sector follows modern world tendencies.
\end{abstract}

Keywords: OTA, hotel, reservation, Booking.com

JEL Codes: D12, G41, Z30, Z33

\section{Introduction}

The increasingly digital environment where hotel services are presented and distributed nowadays exerted a serious influence on the economic performance of hotel enterprises. According to Berne, Garcia-Gonzalez \& Mugica (2012) distributors who use ICT (information and communication technologies) to create their product as expected by consumers will be able to increase their influence and market power. They will gain a more central position, thus taking away influence from other market participants (Lowe, Williams, Shaw \& Cudworth, 2012). End users are changing their shopping and hotel reservations habits, and in this study, we try to identify the new trends and habits of frequent traveller's hotel service booking preferences in Bulgaria.

Hotel managers are facing the complex but sometimes very obvious decision where and how to deploy their inventory in the contemporary business environment. In order to maximize profits of their companies within the current market mechanism it is easy to find the best located and reputable online travel agents who are ready to promote and advertise hotel product. The increasing transaction volumes through OTA's electronic platforms reveal their influence and the major role of online consumer reviews regarding hotel services. Online reviews published on both specialized sites such as TripAdvisor and OTA websites are becoming an important aspect of research in marketing, e-commerce and e-tourism (Filieri \& McLeay, 2013). Therefore, these reviews are playing the role of a significant measurement tool in the hands of

\footnotetext{
${ }^{1}$ Tourism Department, Faculty of Economics, South-West University "Neofit Rilski”, Blagoevgrad isivanov@yahoo.com. ORCID iD https://orcid.org/0000-0003-3411-6645
}

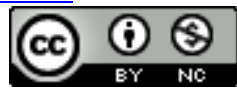

This work is licensed under a Creative Commons Attribution-NonCommercial 4.0 International License. 
hotel managers to evaluate their performance in the aspect of consumer opinions both on a global scale and in Bulgaria.

The tendencies and habits of the changing approaches to the process of making a hotel reservation are considered to point out the digital dependence and the constant online inclusion of Bulgarian frequent travellers and hotel bookers to reveal their consumer preferences, strongly impacted by OTA.

\section{Literature review}

Many hospitality professionals believe that in order to be efficient and competitive, their business must be constantly digitally connected to Computer Reservation Systems (CRS), including Global Distribution Systems (GDS) (Kotler, Bowens \& Makens, 2014). Berne et al. (2012) demonstrate that the use of changes in the balance of market forces generated by Information and Communications Technologies ICTs depends on the market structure and more precisely the number of participants, size, concentration and integration of distributors and consumers, and not so much on the structure of the distribution channel itself. Online travel agencies are taking advantage of the digital technologies and occupy important online distribution channels targeting large numbers of potential consumers and tourists.

Many studies in the field of hotel accommodation point out the leaders among Online Travel Agencies (OTA) such as Expedia group and Booking Holdings, holding the main share of sales and preferences of travellers in many countries, a fact outlined in research by Schegg (2018), Mellinas (2019), European Commission (2017), Bonazzi \& Schegg (2016), MartinFuentes \& Mellinas (2018) and many others. Online travel agencies play a key role in the hotel services sector (Kim, Kim \& Shin, 2009) and gradually online distribution channels have become a traditional way of organizing travel (Law, Chan, \& Goh, 2007). Moreover, the hotel sector is witnessing the widespread use of OTA, both by travellers and hoteliers. In their study, Inversini \& Masiero $(2014$, p. 8 ) found that $79,4 \%$ of the reservations are made online or through an intermediary (OTA, traditional tour operator, email, reservation through the hotel website) and only $20.6 \%$ of the reservations are traditional such as by phone, on site, fax, letter, etc. Some business models of online travel agents and smart business practices, considering the formation of the price, promoted the opportunity for the OTAs to offer better price deals than even hotels do on their websites (Gazzoli, Kim \& Palakurthi, 2008).

In addition, reputation is crucial for building a relationship with customers before the consumption process (Pera \& Viglia, 2016). Online reviews have a tremendous impact on consumer opinion. The high level of trust in online reviews (Gretzel \& Yoo, 2008; Fotis, Buhalis \& Rossides, 2012) can affect overnight sales (Ye, Law \& Gu, 2009; Vermeulen \& Seegers, 2009) and act as an enhancer of tourist confidence, thus reducing the risk associated with booking accommodation (Gretzel, Yoo \& Purifoy, 2007). In 2010, the European Travel Commission issued guidelines and recommendations that hotels should take action to increase their online interaction with their customers. Although positive comments on social media can improve consumer attitudes toward hotels (Vermeulen \& Seegers, 2009), the hotel industry continues to find it difficult to introduce online interaction tools in their communication (Dwivedi, Rana, Chen \& Williams, 2011).

Mellinas (2019) examines the relationship between the number of reviews and the share of reservations made through OTA platforms. This way, approximate information is obtained about the market share of each online travel agent in the distribution matrix of every hotel surveyed. The present study is not addressing hotels or OTA platforms but concentrates on the client directly, outlining his preferences for booking a hotel room in Bulgaria. 


\section{Research methodology and results}

\subsection{Methodology}

For the purpose of the study, an online and quantitative survey was conducted among 150 frequently traveling Bulgarian citizens over the age of 17. Similar studies have been conducted by Inversini \& Masiero (2014), Schegg, Stangl, Fux \& Inversini (2013), Stangl, Inversini \& Schegg (2016) and Schegg (2018), but they are all addressed to hotel sales, while the current study is aimed at consumer behaviour and habits of tourists. Correlation coefficients are derived for some pairs of variables.

The survey was conducted in January 2020 and on the basis of data obtained through descriptive statistics reveals the behaviour of traveling and hotel booking Bulgarian consumers, and highlights the most commonly used „channels" for reservations and sales of hotel reservations and the most influential online booking platforms. The respondents are divided into age groups as follows: 17 to 30 years old, 31 - 44 years old, 45 - 58 years old and people over 58 years. The age groups represent the respective generations. Out of 150 completed questionnaires for the respective questions, the following number of answers was reported: question 1 ,What is the main reason why you book a hotel in Bulgaria" - 147 answers; Question 2 „How do you usually book a hotel room?” and the related question 3 ,Why do you prefer this type of reservation?" in 147 answers; Question 4 ,Which online travel agent do you use most often?” and Question 5 „Why do you prefer this online booking agent?" with 137 answers; Question 6 ,Are you looking for reviews on the Internet about the hotels you book?” - 146 answers. The obtained results are processed with Microsoft Excel, version 2010 and tables and diagrams are compiled in order to more clearly present the results of the empirical study.

\subsection{Results}

Exploring and studying the consumer attitudes and habits of Bulgarian tourists using questionnaires can be presented through a rich set of econometric tools and in this case, we use descriptive statistics. In order to segment the answers of the respondents who participated in the survey, we use two main factors: the purpose of travel and the age of the person who makes a booking, formed in four age groups. The main part of the interviewee's states ,pleasure or rest" as the reason for booking a hotel room $-78.9 \%$, the share of tourists booking for „business travel" is $19 \%$, while the remaining $2.1 \%$ are booking for travel related to „hobby or sport”. It is noteworthy that $60.71 \%$ of the segmented in the group „I travel for work” prefer to book by phone and only $25 \%$ through an online travel agent. In the large group of travellers for leisure and enjoyment, the distribution is quite different as only $34.18 \%$ of them book by phone, while $44.44 \%$ of them use online booking platforms of travel agents such as Booking.com, Airbnb, Trivago, and 10.26\% remain for reservations through the hotel's website or email. Only $7.69 \%$ of the reservations are made with the assistance of a standard tour operator. Respondents traveling for ,sport or hobby” are small in number and cannot provide a correct distribution of their preferences in the booking process.

The empirical results of the survey show some preferences of traveling Bulgarians and the most commonly used way to book a room in Bulgaria - the use of online travel agent (OTA) can be brought to the fore with $41.78 \%$ of all respondents preferring this type of reservation. On the second position, although with a small difference, remain the reservations by phone with a share of $38.36 \%$, outlining the two main approaches when booking hotel rooms. In the background are reservations via email or the website of the hotel with $8.22 \%$ and reservations through traditional travel agents or tour operators with $6.85 \%$. Several respondents also shared other ways of booking, such as „friends help me book a hotel room” and „my company booked me a room". 
Table 1. Type of reservations, according to the distribution channel

\begin{tabular}{|l|c|}
\hline $\begin{array}{c}\text { Type of reservation according to the distribution } \\
\text { channel }\end{array}$ & Percentage \\
\hline Offline reservations & $47.26 \%$ \\
\hline Online reservations & $52.74 \%$ \\
\hline Direct reservations & $46.58 \%$ \\
\hline Indirect (through an intermediary) reservations & $53.42 \%$ \\
\hline
\end{tabular}

Source: Author's research

There is a slight prevalence in the volume of online reservations compared to the traditional offline methods used for booking hotel rooms. This fact underscores the penetration of digital preferences in shopping and booking tourist services and reveals the increasingly transforming economic environment, both globally and locally. Direct bookings also lag behind those made through an intermediary, be it online or offline travel intermediary, confirming the validity today of the process of intermediation in the hotel business. At the turn of the century, disintermediation was identified as a threat to e-travel agents by Buhalis \& Licata (2001), but in fact it now appears that the digital transformation in the sector creates opportunities for development and control of an increasing share of sales of hotel services via E-mediators. Further in the survey follows the question „Which online travel agent do you use most often?" and we find the expected favourite and leader of the European market, and as noted by Schegg (2018): „Booking.com is the most influential OTA with a share of $66.4 \%$ ”. In the study we present the following results in the figure below:

Figure 1. Preferred Online Travel Agent in Bulgaria

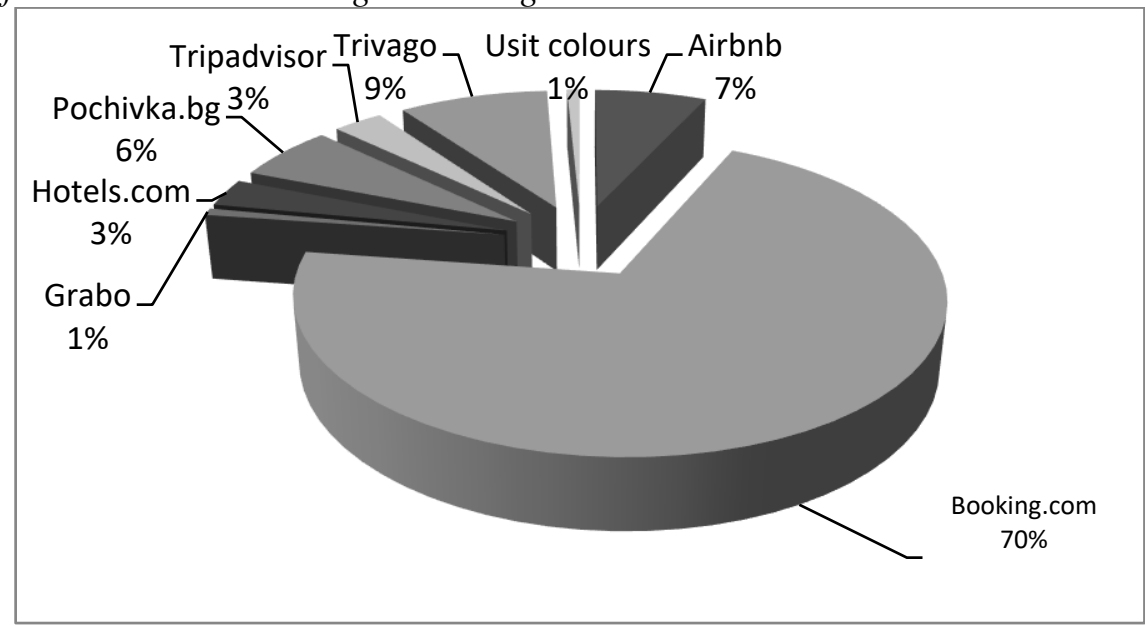

Source: Author's research

Booking.com covers $70.45 \%$ of the respondents' preferences, leaving behind „, Trivago" with 9\%, „Airbnb” with 7\% share and the local online travel agent „Pochivka.bg” with 6\%. To make the data more accurate, the distribution of preferences by age groups is presented as follows in the figure below. 
Figure 2. OTA preferences by age group

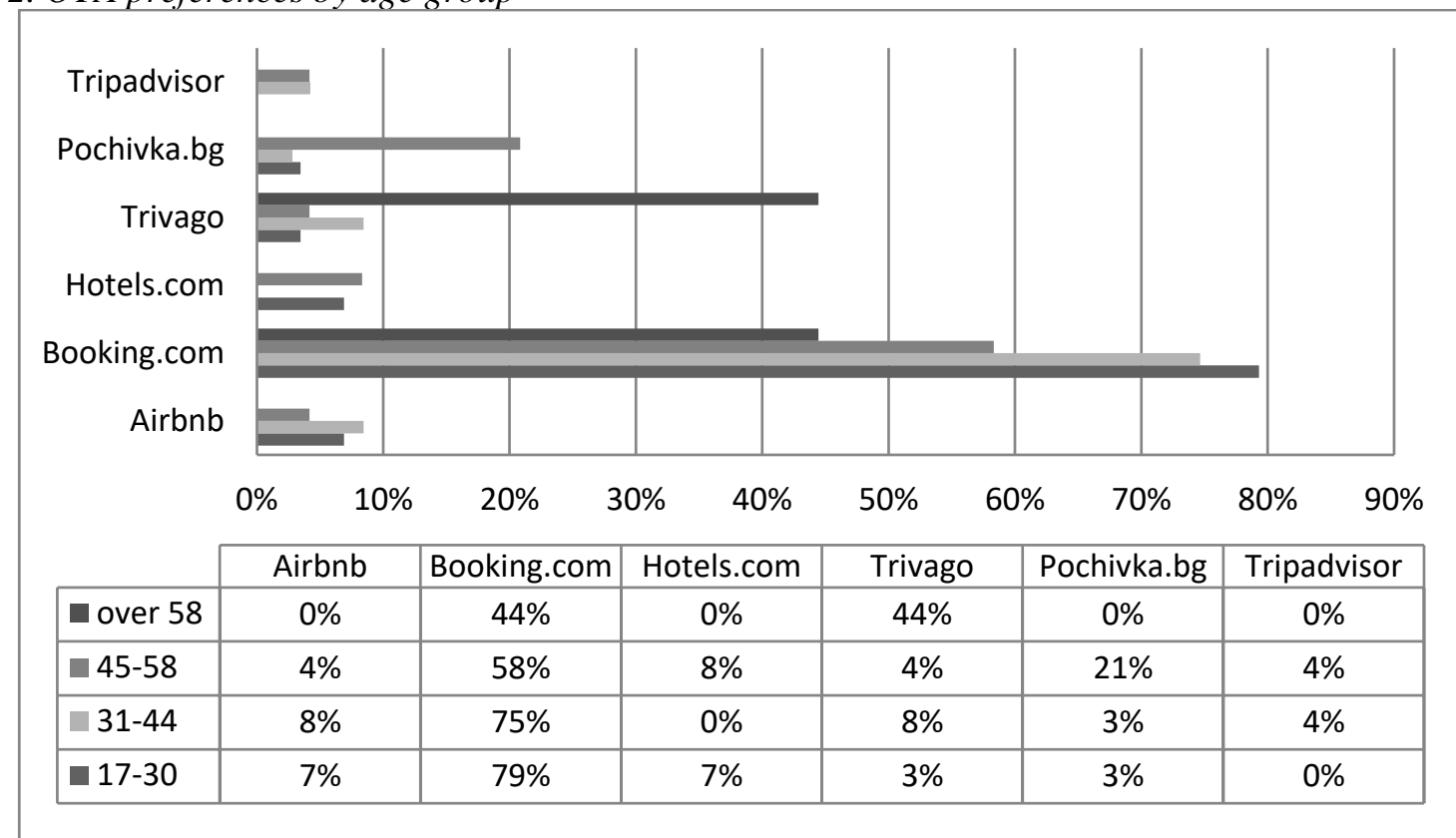

Source: Author's research

There is a growing share of Booking.com among younger age groups, with almost $80 \%$ of 17-30 years olds using this online platform for hotel reservations.

In order to disseminate and distribute the preferred approaches for booking a hotel room according to age, we have prepared the following figure based on question 2 „How do you usually book a hotel room?" from the survey:

Figure 3. Hotel room reservation preferences according age

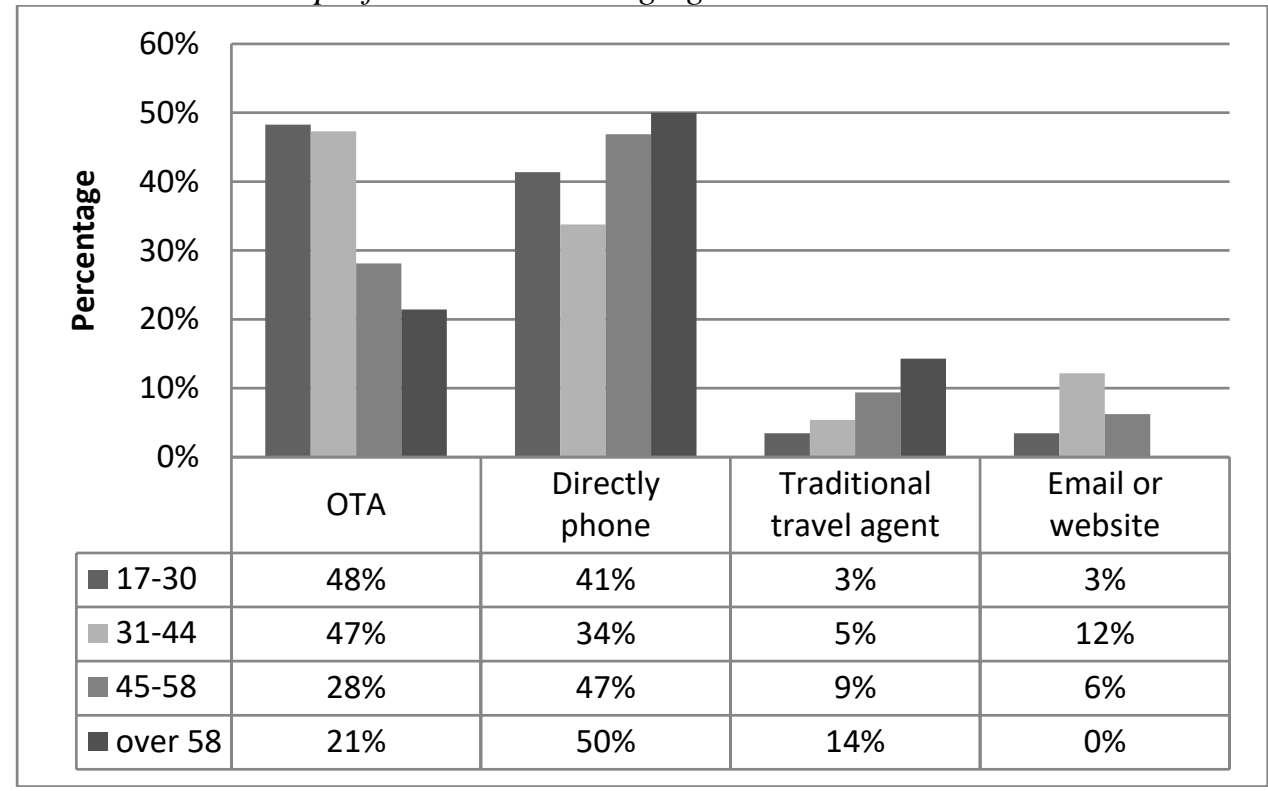

Source: Author's research 
The growing role of online travel agents and the preference of younger generations of Bulgarians for them is evident in the presented data, while on the opposite side are the traditional tour operators and travel agents, left in the background by young people.

Following the sequence of the survey and in connection with the previous question we come to Question 3 ,Why do you prefer this type of reservation?”. The following features of the choice are found: $46.9 \%$ of respondents prefer their chosen method of booking because it is „The most convenient and fast”, respectively $67.14 \%$ of those who show this preference use the online platform of Booking.com for reservations. The next reason for the preferences of modern tourists in Bulgaria is the fact that they feel this technique as „Safest and hassle-free”, with 58.82\% using Booking.com. When it comes to „That's how I get the best price" Booking.com is the preference of half of those looking for a good price. In general, we can say that the price is not the leading factor in making a reservation, while convenience, speed and security are factors which turn out to be more important than the price level of the offered tourist services. The data presented so far give a strong preference to online travel agents and specifically to the Dutch-based internet portal Booking.com. These modern trends are visible in the „Google Travel study“ (Vidal, 2019), which found that $74 \%$ of travellers plan their vacation online and only $13 \%$ of tourists continue to use traditional tour operators and travel agents. Trying to find the relationships between the age group of tourists and their preferences and techniques in the booking process, we calculate the linear correlation, using the Pearson coefficient - $r$, to reveal the following numerical expressions and dependencies: The data presented so far give a strong preference to online travel agents and specifically to the Dutchbased internet portal Booking.com. These modern trends are visible in the „Google Travel study" (Vidal, 2019), which found that $74 \%$ of travellers plan their vacation online and only $13 \%$ of tourists continue to use traditional tour operators and travel agents. Trying to find the relationships between the age group of tourists and their preferences and techniques in the booking process, we calculate the linear correlation, using the Pearson coefficient - $r$, to reveal the following numerical expressions and dependencies:

Table 2. Pearson linear correlation coefficient

\begin{tabular}{|l|l|l|}
\hline \multicolumn{1}{|c|}{$\begin{array}{c}\text { Pairs of variables: age - type of reservation, age - } \\
\text { preferred OTA }\end{array}$} & Pearson - r & \multicolumn{1}{c|}{$\begin{array}{c}\text { Strength and direction of } \\
\text { relationship }\end{array}$} \\
\hline Age group - reservation through OTA & -0.951 & Very strong, negative relation \\
\hline Age group - reservation by phone & 0.723 & Strong, positive relationship \\
\hline $\begin{array}{l}\text { Age group - reservation using traditional travel } \\
\text { agency }\end{array}$ & 0.991 & Very strong, positive dependence \\
\hline Age group - reservation by email or website & -0.444 & Moderate, negative relation \\
\hline Age group - Booking.com & -0.985 & Very strong, negative relation \\
\hline Age group - Airbnb & -0.889 & Very strong, negative relation \\
\hline
\end{tabular}

Source: Author's research

There is a strong and visible trend related to the dependence between the age group of tourists and their choice of booking approach and online travel agent. The strong and even very strong correlation is indicative, while in terms of reservations by email or via the hotel's website we do not observe a serious dependence on the age of the bookers. We can note that due to the insufficient number of respondents we cannot accept these data as representative. This fact is the main limitation for the accuracy and validity of the study. 
The answers of question 5 „Why do you prefer this online booking agent?“ are not limited to a single choice and give several answer options, the most frequently repeated answer is „I can check the reviews of previous guests“ with 61 answers. A large number of favourites are given to „This is how I get the best price“ - 46, „It is reliable and secure“ - 45 answers and „I can compare several hotels in the destination where I am looking for accommodation" with 40 preferences.

Question 6,AAre you looking for reviews on the Internet for the hotels you book?“ gives the following optional answers: „Always search on Booking.com“ with 31.51\%, „Sometimes I search, sometimes not“" with $23.30 \%$, „I look for information in different online platforms TripAdvisor, Google, Booking.com“ with $39.73 \%$ and „I do not check hotels for reviews on the Internet at all" with $5.48 \%$. The two options involving searching for reviews on online platforms and specifically on Booking.com collect a total of over $70 \%$ of preferences, as half of those looking for information on different online platforms actually book directly by phone, and $1 / 3$ of those using Booking.com for information also book hotel services by phone. This feature of the booking process reveals that often the consumers use multi-channel information gathering before resorting to a certain distribution channel where to book a hotel product. This is point where a modern shopping phenomenon called „,cross-channel free-riding” (Chiou, Wu, \& Chou, 2012; Chui, Hsieh, Roan, Tseng \& Hsieh, 2011; Starkov \& Price, 2007; Van Baal \& Dach, 2005) is observed or literally translated as „free travel through distribution channels“. This recent consumer behaviour is the acquisition of free information about the products and services they wish to obtain or use, followed by a purchase through the most convenient and inexpensive channel, seller or manufacturer. An example can be given when a user ,likes" a hotel in a destination and after checking the prices on the Internet makes a direct reservation by phone, a move that saves costs for the expense of time used for „market research“. According to Chevalier (2002), this phenomenon is associated with increased use of the Internet, while Heitz-Spahn (2013) emphasizes that added value is gained in the context of multichannel trading.

\section{Discussion}

The outlined approximate parity between the reservations through digital channels and the traditional ones is impaired by the increasing preferences of the younger generations in Bulgaria. The fact is that Generation "Y"- Millennials, currently in its active age, dictates the trends in the development of the hotel business in Bulgaria with its ability to collect and use information quickly, accurately and online. There is a visible trend that turns online travel agents into a major driving force in the digital market worldwide and in our country as a special case. The timely provision of relevant and rich information is identified as a major factor in the differentiation of the online market and directs the modern consumer more and more to the daily use of the services of companies in the online tourism sector. At the same time, traditional electronic channels for selling hotel products and services are disappearing in the background. The study rediscovers the market leader for online reservations in the face of Booking.com, holding a very significant share compared to other OTAs selling hotel services as intermediaries in Bulgaria. The influence of the Dutch rooted online travel agent is so strong that it brings the market situation in the field of OTA business closer to a monopoly. Since the beginning of the century there was a clear pathway opened for the entry of OTAs, according to some authors, and the growing role of online travel agents in the modern hotel product market was established by factors that emerged like the widespread use of the Internet and the creation and imposition of brands who inspire confidence in the consumers. To illustrate vividly the contemporary state of art and future expectations for the tourist products and services market is used a figure of Law, Leung, Lo, Leung \& Fong (2015) as seen below: 
Figure 4. Transformation of the share of hotel and travel reservations (past, present and future)

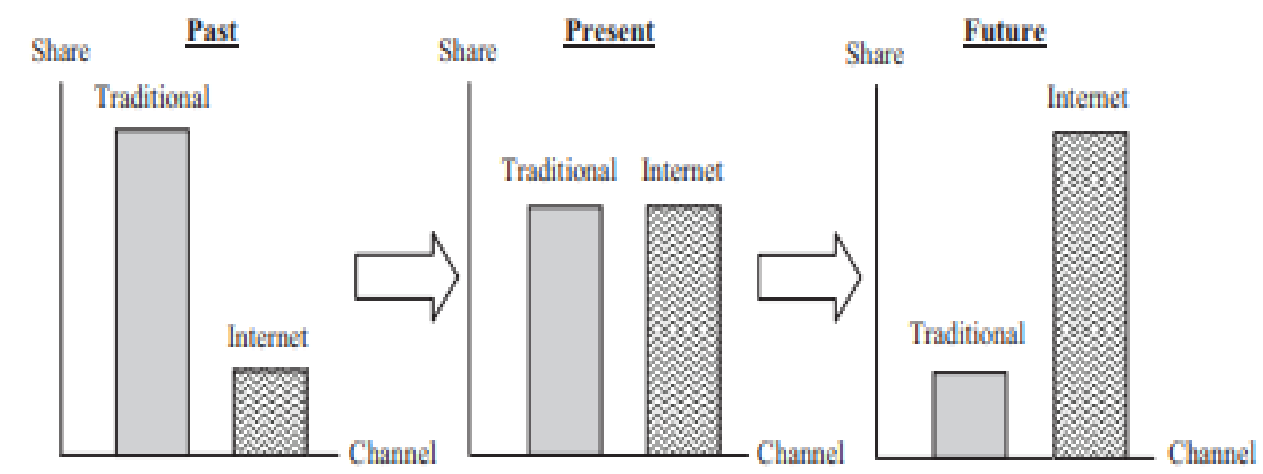

Source: Law, Leung, Lo, Leung \& Fong, 2015

The opinion of Law et al. (2015) shows that internet travel agents are in a level playing field and are gradually increasing their influence at the expense of traditional travel agents, which in turn stimulates the traditional travel agent to invest and enter the online market of modern e-travel agents. New e-travel agents still need to make efforts to develop cooperation with hotel product suppliers and to offer the best to clients through a system of online platforms. There has been a concentration of capital and resources in several major e-hotel providers such as Booking.com and Expedia, as well as the formation of collaborations and alliances (Ctrip is collaborating with Booking.com to be able to go beyond the Asian market, as well as the US platform to take place in Asia, through its Chinese partner). In this way, costs are minimized and commissions are increased, which is a catalyst for the rapid growth of online sales in the hotel sector. The number of online travel agents is increasing daily as several larger companies hold the main market in the world and are in an almost monopoly position, namely Booking Holdings (formerly Priceline) and Expedia, through their OTA branches and meta search engines, while other digital travel agents are emerging as regionally important agents such as Ctrip in China and Travel.ru in Russia. The main players Booking Holdings and Expedia Group have conquered the market of online travel agencies with a share of $83 \%$ of all hotel sales via OTA in Europe in 2017 (Schegg, 2018). The annual report of Phocuswright (2020), regarding the OTA market in the US reveals that Expedia and Booking.com retain a total share of $92 \%$ of all bookings on the market of online travel agencies, which is indicative of the huge market power and influence of these two companies on the market situation in this segment of tourism. According to Buhalis and Licata (2001), new e-intermediaries will inevitably go through a process of natural selection that will separate the stronger players - those with sound business models, stability and expansion - from those who fail. The probability of finding and placing in the right niche and the formation of partnerships, filling market needs and image will be an essential factor for the development of online distributors of hotel reservations. Interestingly, customers tend to be more loyal to OTA than to the brand of the provider itself - this is explained by greater security in payments, options for selection and filtering criteria that OTAs provide (Green \& Lomanno, 2014). When consumers buy a tourism product or service from OTA, they expect to receive value, loyalty and quality services (Bizirgianni \& Dionysopoulou, 2013). 


\section{Conclusion and Recommendations}

The change in consumer sentiment in the field of tourism and hospitality, and their digital transformation is inevitable in today's conjuncture. Bulgarians follow the global trend of an ever-increasing digitally connected world and technology as a part of everyday life. Along with new technologies, tourism enterprises and hotels in particular are being transformed, which is changing their strategies for development and operational management practices, turning them into consumer-oriented tourism organizations. From the point of view of consumer preferences, their competitiveness increasingly depends on their ability to use ICT strategically and tactically in order to improve their positioning in the preferences of the client. The Internet and ICT are making a difference in the tourism by converting companies in the sector from product-oriented to consumer-oriented. Based on the obtained data and the analysis of the results, the present study outlines the specifics of the local tourist market in Bulgaria, considering the behaviour and habits of tourists in the reservation process, and taking into account the possible behavioural characteristics of the hotel companies to achieve business benefits and success. The conducted research can serve as a basis for future more serious and in-depth study of the trends in the country's hotel business. The collected data are a rich source of information, regardless of their limitations in terms of representation and are a serious starting point for studying the consumer habits of consumers in the tourism sector in Bulgaria. Information about these preferences is a serious starting point for the direction in which modern hotel managers should steer their marketing efforts. Knowledge of the preferences of young generations of tourists shows the digital transformation in the sector and motivates those working in the sector to rethink the way they need to offer and sell their product. The small number of reservations made through own web channels (email and website) of the hotels in Bulgaria show the direction, in which it is necessary to focus the efforts of hotel managers in order to diversify the sources of reservations and sales. The information generated by the study is valuable and would stimulate the adaptation of tourism resources at a micro and macro level related to the individual wishes and demands of tourists to ensure the improvement of their satisfaction with hotel services and to guarantee a process of fair distribution of resources among participants on the market of tourist services in Bulgaria. 


\section{References}

Berne, C., Garcia-Gonzalez M., \& Mugica, J. (2012). How ICT Shifts the Power Balance of Tourism Distribution Channels. Tourism Management, 33(1), 205-14. https://doi.org/10.1016/j.tourman.2011.02.004

Bizirgianni, I., \& Dionysopoulou, P. (2013). The influence of tourist trends of youth tourism through social media (SM) \& information and communication technologies (ICTs). Procedia-Social and Behavioral Sciences. https://doi.org/10.1016/j.sbspro.2013.02.102

Bonazzi, R., \& Schegg, R. (2016). An Alternative to Online Travel Agencies for Retention of Hotel Customers. 2016 ENTRENOVA Conference Proceedings, Retrieved from https://ssrn.com/abstract $=3282253$

Buhalis, D., \& Licata M. C. (2001). The Future e-Tourism intermediaries. Tourism Management, 23(3), 207-220.

Chevalier, J.A. (2002). Free riders issues and Internet retailing. Retrieved from http://www/ftc.gov/opp/ecommerce/anticompetitive

Chiou, J. S., Wu, L. Y., \& Chou, S. Y. (2012). You do the service but they take the order. Journal of Business Research, 65(7), 883-889. https://doi.org/10.1016/j.jbusres.2011.06.035

Chui, H. C., Hsieh, Y. C., Roan, J., Tseng, K. J., \& Hsieh, J. K. (2011). The challenge for multichannel services: cross-channel free-riding behaviour. Electronic Commerce Research and Applications, 10(2), 268-277. https://doi.org/10.1016/j.elerap.2010.07.002

Dwivedi, Y. K., Rana, N. P., Chen, H., \& Williams, M. D. (2011, September). A Metaanalysis of the Unified Theory of Acceptance and Use of Technology (UTAUT). In IFIP international working conference on governance and sustainability in information systems-managing the transfer and diffusion of it. 155-170. Springer, Berlin, Heidelberg. https://doi.org/10.1007/978-3-642-24148-2_10

European Commission. (2017). Report on the monitoring exercise carried out in the online hotel booking sector by EU competition authorities in 2016. Retrieved from http://ec.europa.eu/competition/ecn/hotel_monitoring_report_en.pdf

Filieri, R., \& McLeay, F. (2013). E-WOM and Accommodation: An Analysis of the Factors That Influence Travelers' Adoption of Information from Online Reviews. Journal of Travel Research, 53(1), 44-57. https://doi.org/10.1177\%2F0047287513481274

Fotis, J., Buhalis, D., \& Rossides, N. (2012). Social Media Use and Impact during the Holiday Travel Planning Process, January 2012, DOI: 10.1007/978-3-7091-1142-0_2

Gazzoli, G., Kim, W. G., \& Palakurthi, R. (2008). Online distribution strategies and competition: Are the global hotel companies getting it right? International Journal of Contemporary Hospitality Management, 20(4), 375-387.

https://doi.org/10.1108/09596110810873499 
Green, C., \& Lomanno, M. (2014). Distribution Channel analysis: A guide for hotels. AH\&LA and STR Special Report. Retrieved from https://invattur.softvt.com/ficheros/noticias/107141153A_distribution_channel_analys is, guid_for_hotels_(1).pdf

Gretzel, U., \& Yoo, K. (2008). Use and Impact of Online Travel Reviews, Conference: Information and Communication Technologies in Tourism. ENTER 2008, Proceedings of the International Conference in Innsbruck. Austria, 2008. DOI: 10.1007/978-3-211-77280-5_4

Gretzel, U., Yoo, K., \& Purifoy, M. (2007). Online Travel Review Study: Role and Impact of Online Travel Reviews. Austin, TX: Laboratory for Intelligent Systems in Tourism, Texas A\&M University.

Inversini, A., \& Masiero, L. (2014). Selling Rooms Online: The Use of Social Media and Online Travel Agents. International Journal of Contemporary Hospitality Management, 26(2), 272 - 292. https://doi.org/10.1108/IJCHM-03-2013-0140

Kim, H., Kim, T., \& Shin, S. W. (2009). Modelling roles of subjective norms and e-Trust in customers' acceptance of airline B2C eCommerce websites. Tourism Management, 30(2):266-277. https://doi.org/10.1016/j.tourman.2008.07.001

Kotler, Ph., Bowens, J., \& Makens, J. (2014). Marketing for Hospitality and Tourism: 6th Edition, Pearson.

Law, R., Chan, I., \& Goh, C. (2007). Where to find the lowest hotel room rates on the internet? The case of Hong Kong. International Journal of Contemporary Hospitality Management, 19(6), 495-506. https://doi.org/10.1108/09596110710775156

Law, R., Leung, R., Lo, A., Leung, D., \& Fong, L. (2015). Distribution channel in hospitality and tourism. International Journal of Contemporary Hospitality Management, 27(3), 431 - 452. https://doi.org/10.1108/IJCHM-11-2013-0498

Lowe, M., Williams, A., Shaw, G., \& Cudworth, K. (2012). Self-Organizing Innovation Networks, Mobile Knowledge Carriers and Diasporas: Insights from a Pioneering Boutique Hotel Chain. Journal of Economic Geography, 12(5), 1113-1138. DOI: $10.1093 / \mathrm{jeg} / \mathrm{lbs} 021$

Martin-Fuentes, E., \& Mellinas, J. (2018). Hotels that most rely on Booking.com - online travel agencies (OTAs) and hotel distribution channels. Tourism Review, 73(4), 465479. https://doi.org/10.1108/TR-12-2017-0201

Mellinas, J. (2019). Dependency of Spanish urban hotels on Booking.com. 9th World Conference for Graduate Research in Tourism Hospitality and Leisure, Cartagena, Spain. https://doi.org/10.3727/108354219X15458295631909 
Pera, R., \& Viglia, G. (2016). Exploring how video digital storytelling builds relationship experiences. Psychology and Marketing, 33(12), 1142-1150. https://doi.org/10.1002/mar.20951

Phocuswright Research (2020). European travel market advances thanks to online mobile and leading suppliers. Retrieved from https://tinyurl.com/y9yrjmac

Heitz-Spahn, S. (2013). Cross-channel free-riding consumer behaviour in a multichannel environment: An investigation of shopping motives, sociodemographic and product categories. Journal of Retailing and Consumer Services, 20(6), 570-578. https://doi.org/10.1016/j.jretconser.2013.07.006

Schegg, R. (2018). European Hotel Distribution Study Results for the Reference Year 2017, Institute of Tourism, HES-SO Valais, May 18, 2018. Retrieved from https://tinyurl.com/y4cavmmx

Schegg, R., Stangl, B., Fux, M., \& Inversini, A. (2013). Distribution Channels and Management in the Swiss Hotel Sector. Proceedings of Information and Communication Technologies in Tourism, 554-565. Presented at the ENTER2013, Innsbruck: Springer. DOI: 10.1007/978-3-642-36309-2_47

Stangl, B., Inversini, A., \& Schegg, R. (2016). Hotels' dependency on online intermediaries and their chosen distribution channel portfolios: three country insights. International Journal of Hospitality Management, 52, 87-96. https://doi.org/10.1016/j.ijhm.2015.09.015

Starkov, M., \& Price, J. (2007). What Hot Internet Marketing Topics Are on the Minds of Hoteliers? HeBs Digital. Retrieved from https://www.hospitalitynet.org/opinion/4032615.html

Van Baal, S., \& Dach, C. (2005). Free-riding and customer retention across retailers' channel. Journal of Interactive Marketing, 19(2), 75-85. https://doi.org/10.1002/dir.20036

Vermeulen, I., \& Seegers, D. (2009). Tried and Tested: The Impact of Online Hotel Reviews on Consumer Consideration. Tourism Management, 30(1), 123-127. https://doi.org/10.1016/j.tourman.2008.04.008

Vidal, B. (2019, December 05). The New Technology and Travel Revolution. Business Intelligence \& Analytics. Retrieved from https://tinyurl.com/vj7ktrh

Ye, Q., Law, R., \& Gu, B. (2009). The Impact of Online User Reviews on Hotel Room Sales. International Journal of Hospitality Management, 28(1), 180-182. https://doi.org/10.1016/j.ijhm.2008.06.011 


\title{
FORECASTING OF SOME KEY INDICATORS OF THE RFI AND RFP PROCESSES OF THE BULGARIAN MOBILE TELECOMMUNICATION OPERATORS
}

\section{AVGUSTIN MILANOV ${ }^{1}$}

\begin{abstract}
The present paper regards the opportunities of forecasting of some key indicators in the "Request for Information" (RFI) and "Request for Proposal" (RFP) processes in the supply chain at the Bulgarian mobile telecommunication operators. The presented hereby forecasting is based on the use of the Holt-Winters method for exponential smoothing in the presence of additive and multiplicative seasonality and is made or indicators: "number of contracts", "number of contracts with savings" and "number of the issued purchase orders". The lowest "Stationary $R$ square", " $R$ square" and MAPE (Mean Absolute Percentage of Error) values are used as measurement of accuracy and for selection of the best fit models that are applied. It is also important to point out that the measurement is being done for the socalled "bottle necks" or "narrow places" in the RFI and RFP processes. The purpose of this bottle-neck forecasting is to provide timely point for "Go/Not Go" decisions point for these very same process and thus to result in an improved risk management in the form of risk aversion and risk minimization.
\end{abstract}

Keywords: forecasting, Holt-Winters exponential smoothing, supply chain management, risk management, RFI and RFP process, telecommunication operators

JEL Codes: L93, O18, F47

\section{Introduction}

The present paper regards the opportunities of forecasting of some key indicators in the "Request for Information" (RFI) and "Request for Proposal" (RFP) processes in the supply chain at the Bulgarian mobile telecommunication operators. The presented hereby forecasting is based on the use of the Holt-Winters method for exponential smoothing in the presence of additive and multiplicative seasonality and is made or indicators: "number of contracts", "number of contracts with savings" and "number of the issued purchase orders". The lowest "Stationary R square" "R square" and MAPE (Mean Absolute Percentage of Error) values are used as measurement of accuracy and for selection of the best fit models that are applied. It is also important to point out that the measurement is being done for the so-called "bottle necks" or "narrow places" in the RFI and RFP processes. The purpose of this bottle-neck forecasting is to provide timely point for "Go/Not Go" decisions point for these very same processes and thus to result in an improved risk management in the form of risk aversion and risk minimization.

\section{Literature review and some basic concept notes}

${ }^{1}$ Faculty of Economics, South-West University “Neofit Rilski”, 60 Ivan Mihailov str, Blagoevgrad 2700, Bulgaria, email: avgustin.milanov@gmail.com ORCID iDhttps://orcid.org/0000-0002-9968-7273

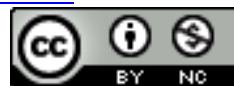

This work is licensed under a Creative Commons Attribution-NonCommercial 4.0 International License. 
The present paper's approach for forecasting of the key indicators in the RFI and RFP process in the supply chain of mobile telecommunication operators in based on the univariate methods of forecasting, or more specifically on the use of the exponential smoothing forecasting methods. As Preslav Dimitrov $(2012,2020)$ points out the development and usage of the univariate and particularly of the exponential forecasting methods dates back from the works of R. G. Brown (1959) in the 1940's the results of which were published in 1959. These were further developed and expanded by C. C. Holt (1957) and Peter Winters (1960). In 1960's Pegles (1969) developed the first taxonomy for the classification of the available at that time exponential smoothing forecasting methods. In the 1980's Gardner $(1985,1987)$ presented some interesting techniques aimed at smoothing of the error residuals in the achieved forecasts. Gardner (1985) and Taylor (2003) also further expanded the opportunities for classifying the exponential smoothing forecasting methods according to so-called "forecasting profiles" or "forecasting patterns".

The problem of the initialization of variables that are to be used in the exponential smoothing equations was also regarded by numerous authors such as Ledolter and Abraham (1984) and Hyndman (2014). Hyndman, Koehler, Snyder, Grose (2002) and Hyndman, Koehler, Ord and Snyder (2008) published their works on the usage of the so-called state-space approach in exponential smoothing.

In the years, the capacity of the univariate and particularly of the exponential forecasting methods to produce reliable forecast was further explored also by other researchers such Ledolter and Abraham (1984), Gardner and McKenzie (1985, 1988), Chatfield and Yar (1988), Hamilton (1994), Tashman and Kruk (1996), Delurgio (1998), Williams and Miller (1999), Tsay (2005) and many others.

In Bulgaria, up to the 1990's only a small portion of the univariate forecasting methods (actually the simplest ones) and the exponential smoothing methods were virtually unknown due to the weak English language skills of the researchers and the preference given in the field of forecasting to the multivariate forecasting methods and mainly the usage of French and Swedish econometric models. In 1996 Sirakov published a book named "Conjuncture and Forecasting of International Markets" in which an application of the Brown's single exponential smoothing was made in regards to the Bulgarian export of textile production equipment and machinery for the African countries and mainly in Nigeria. This application was however very narrow in scope. An Internet publication that tried to make the exponential forecasting smoothing methods more popular in Bulgaria was published in 2007 by Ivanov (2007) from the New Bulgarian University as a part of his lecture course materials on business processes forecasting. Another try for a more explicit explanation and usage of the exponential forecasting methods and namely the Halt and Halt-Winters method was made in another book published in Bulgarian language by Mishev and Goev (2012), i.e. "Statistical analysis of time series". Even though, however, the theoretical presentation of the regarded method was limited and narrowed to the practical application of several software packages. In the field of the Bulgarian tourism, the published studies in the application of the exponential smoothing methods up to 2010 were also limited. However, within the period of 2010 up to 2020, a significant number of publications were made by Dimitrov (2010, 2011, 2012, 2013), Dimitrov, Krasteva and Mirchova (2014), Dimitrov, Kalinova, Gantchev and Nikolov (2015), Dimitrov and Stoyanova (2015) (2016), Dimitrov, Daleva and Stoyanova (2016) (2017), as well as by Dimitrov, Krasteva, Dimitrov and Parvanov (2018). All these publications regard the use of the Halt and Halt-Winters methods for forecasting of the number of tourism arrivals, the tourism receipts and the tourism remunerations in Bulgaria, as well as within certain micro tourism destinations within this country. 


\section{Methodology and main results}

For the needs of the research that stands for the present paper, as well as taking into account of the extremely dynamic development of the sector of the mobile telecommunication operators both globally and in Bulgaria, as well as the capacity of these very same mobile operators to produce and store big volumes of data including time series for their RFI and RFP process, the method of Holt-Winters was selected for carrying out of the necessary forecasting.

The mathematical notation of the Holt-Winters method for multiplicative seasonality, as pointed by Dimitrov et al. (2016) is as follows:

$>$ The smoothing of the level (the base) - "B":

(1)

$$
B_{t}=\alpha \frac{Y_{t}}{S_{t-L}}+(1-\alpha)\left(B_{t-1}+T_{t-1}\right) \quad 0 \leq \alpha \leq 1
$$

The smoothing of the trend - "T":

(2)

$$
T_{t}=\beta\left(B_{t}-B_{t-1}\right)+(1-\beta) T_{t-1} \quad 0 \leq \beta \leq 1
$$

The smoothing of the seasonal (cyclicity) factor - "S":

(3)

$$
\left.S_{t}=\gamma \frac{Y_{t}}{B_{t}}+(1-\gamma) S_{t-L} \quad 0 \leq \gamma \leq 1\right)
$$

The calculation of the final forecast " $\mathbf{F}_{\mathbf{t}+\mathbf{m}}$ " for " $\mathbf{t + m}$ " the period ahead of time:

$$
F_{t+m}=\left(B_{t-1}+m T_{t-1}\right) S_{t+m-L},
$$

Where:

, $\alpha$ ", , $\beta$ " and " $\gamma$ " are the smoothing constants for the base, trend and seasonality (cyclicity), which can take the value between 0 and 1 .

And the mathematical notation of the Holt-Winters method in the presence of additive seasonality is as follows (Dimitrov et al., 2016):

$>$ The smoothing of the level (the base) - "B":

(5)

$$
B_{t}=\alpha\left(Y_{t}-S_{t-L}\right)+(1-\alpha)\left(B_{t-1}+T_{t-1}\right) \quad 0 \leq \alpha \leq 1
$$

The smoothing of the trend - "T":

(6)

$$
T_{t}=\beta\left(B_{t}-B_{t-1}\right)+(1-\beta) T_{t-1} \quad 0 \leq \beta \leq 1
$$

he smoothing of the seasonal (cyclicity) factor - "S":

(7)

$$
S_{t}=\gamma\left(Y_{t}-B_{t}\right)+(1-\gamma) S_{t-L} \quad 0 \leq \gamma \leq 1
$$

The calculation of the final forecast " $F_{t+m}$ " for " $t+m$ " the period ahead of time:

$$
F_{t+m}=B_{t-1}+m T_{t-1}+S_{t+m-L},
$$

Where:

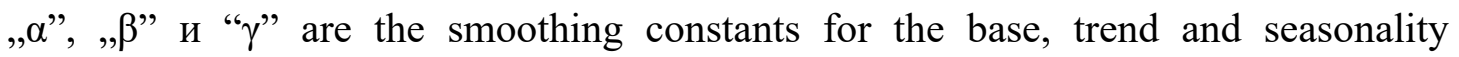
(cyclicity), which can take the value between 0 and 1 .

The initialization of the values of the level "B", the trend " $T$ " and the seasonal factor "S" is achieved though the following set of equations $(9,10,11$ and 12$)$ :

$>$ For the level (base) " $B_{0}$ ": 
(9)

$$
B_{0}=\frac{1}{L}\left(Y_{1}+Y_{2}+\ldots Y_{L}\right)
$$

For the trend " $\mathbf{T}_{\mathbf{0}}$ ":

(10)

$$
T_{0}=\frac{1}{L}\left(\frac{Y_{L+1}-Y_{1}}{L}+\frac{Y_{L+2}-Y_{2}}{L}+\ldots+\frac{Y_{L+L}-Y_{L}}{L}\right)
$$

For the seasonality (cyclic) factor - "S $\mathbf{S}_{\mathbf{0}}$ ":

$$
S_{0}=\frac{1}{N} \sum_{j=1}^{N} \frac{Y_{L(j-1)+i}}{A_{j}} \quad \forall_{i}=1,2, \ldots, L,
$$

Where:

$$
A_{j}=\frac{\sum_{i=1}^{L} Y_{L(j-1)+i}}{L} \quad \forall_{j}=1,2, \ldots, N,
$$

$A j$ represents the average value of $Y$ where $\mathrm{j}$ is the concerned time series.

Here, for the initialization of the seasonal factor other alternative methods are also available and Hyndman (2014) recommends the following approach for the multiplicative seasonality:

(13)

$$
S_{o}=Y_{i} / B_{m}, \text { where } \mathrm{i}=1, \ldots, \mathrm{m} \text {. }
$$

However, the present paper will use equation (11) even if it is a little bit more complex to achieve and is close to an autoregressive approach for initialization of the seasonal indices.

The Forecasting the basic parameters of the RFI and RFP processes is made through indicators: "number of contracts", "number of contracts with savings" and "number of the issued purchase orders". The forecasting itself is carried out by the use of the Holt-Winters exponentials smoothing in the presence of additive and multiplicative seasonality, based on the lowest "Stationary R square", "R square" and MAPE values (Figure1, Figure 2, Figure 3, Figure 4, Figure 5 and Figure 6).

Figure 1. Number of contracts - additive cyclicity

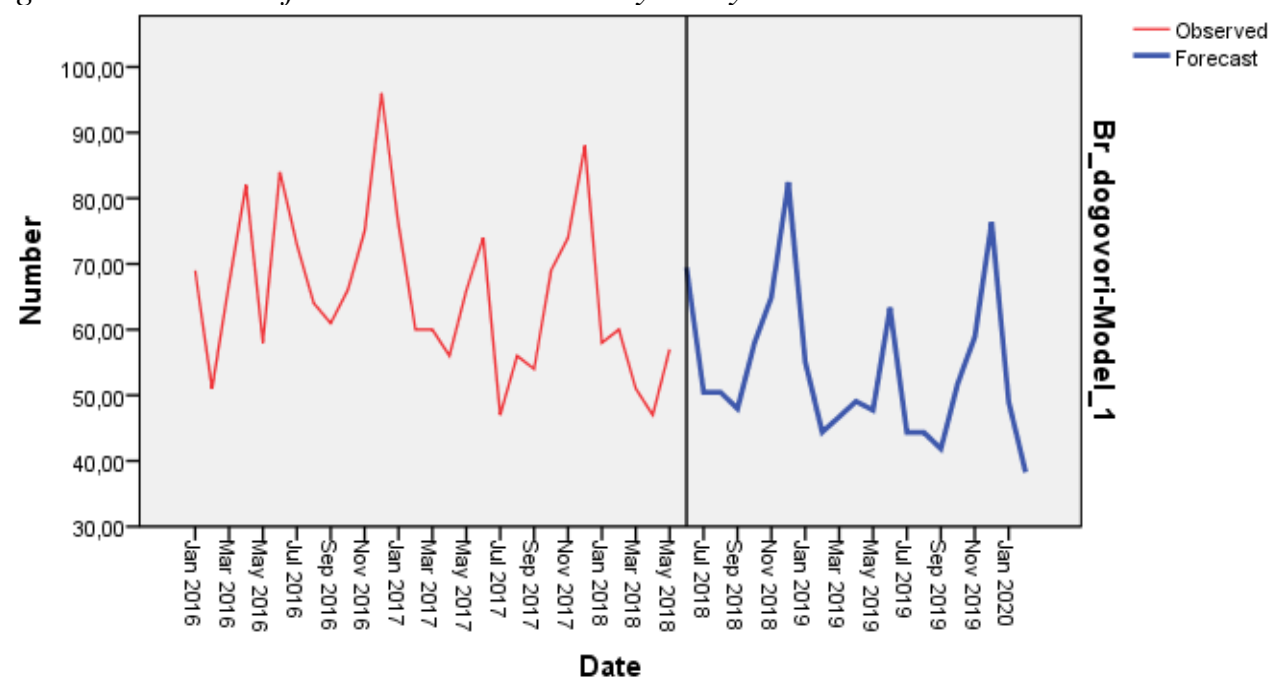

Source: Author's own calculations (2020) 
Figure 2. Number of contracts - multiplicative cyclicity

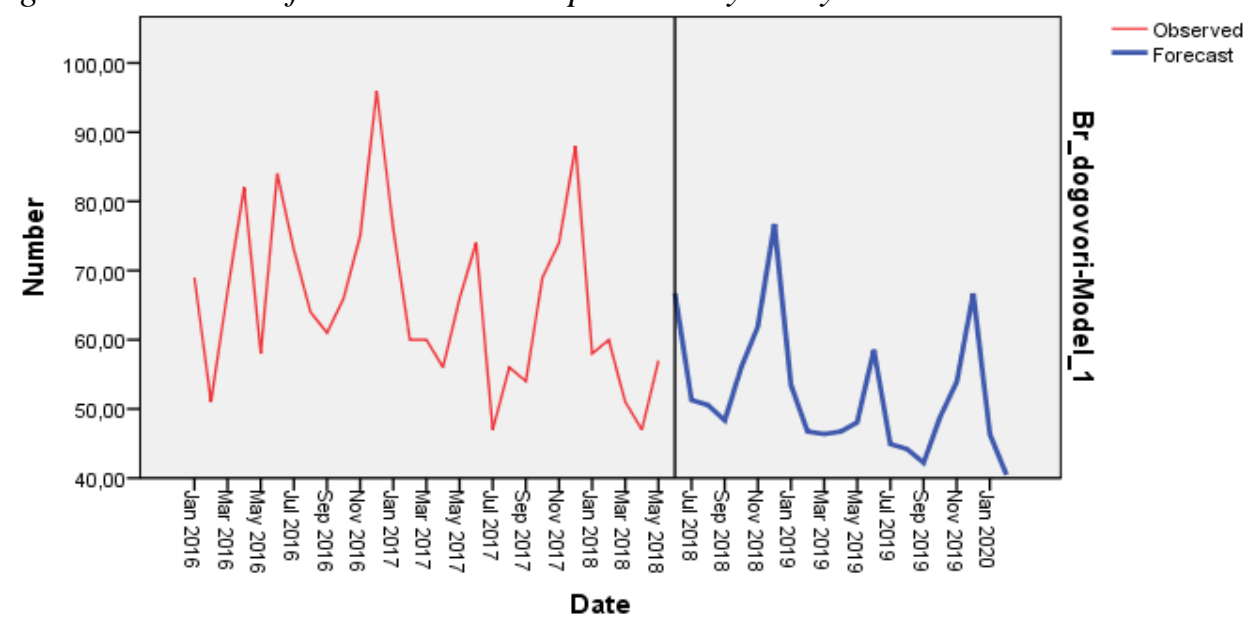

Source: Author's own calculations (2020)

Figure 3. Number of issued purchase orders - additive cyclicity

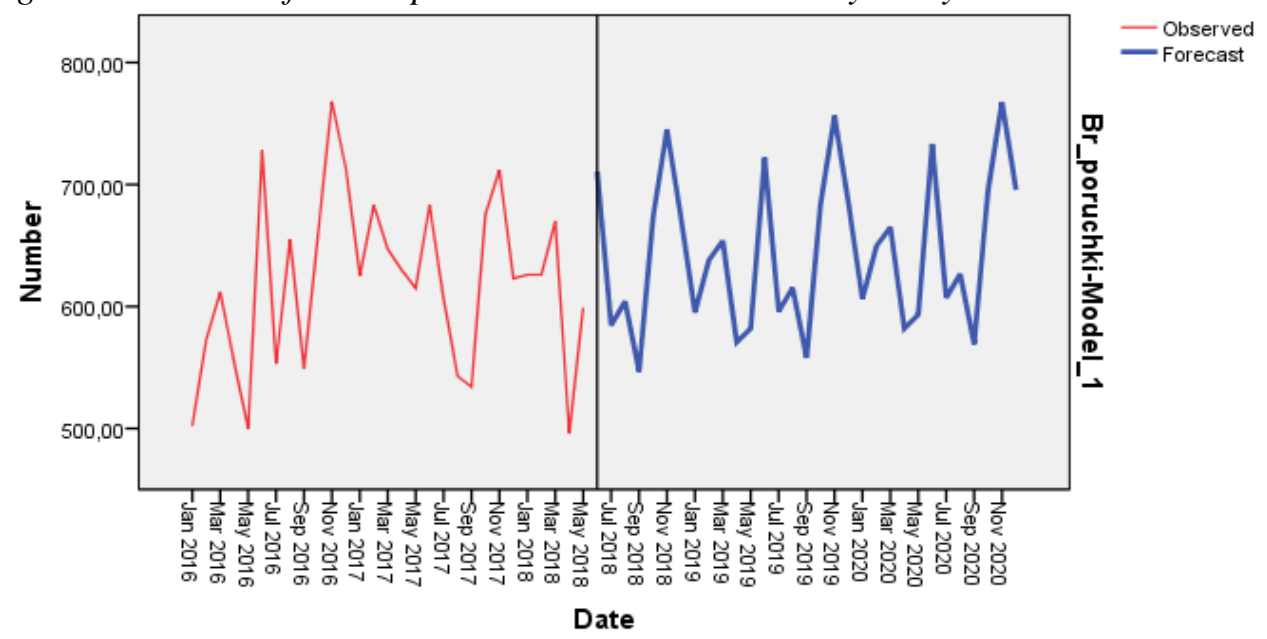

Source: Author's own calculations (2020)

Figure 4. Number of issued purchase orders - multiplicative cyclicity

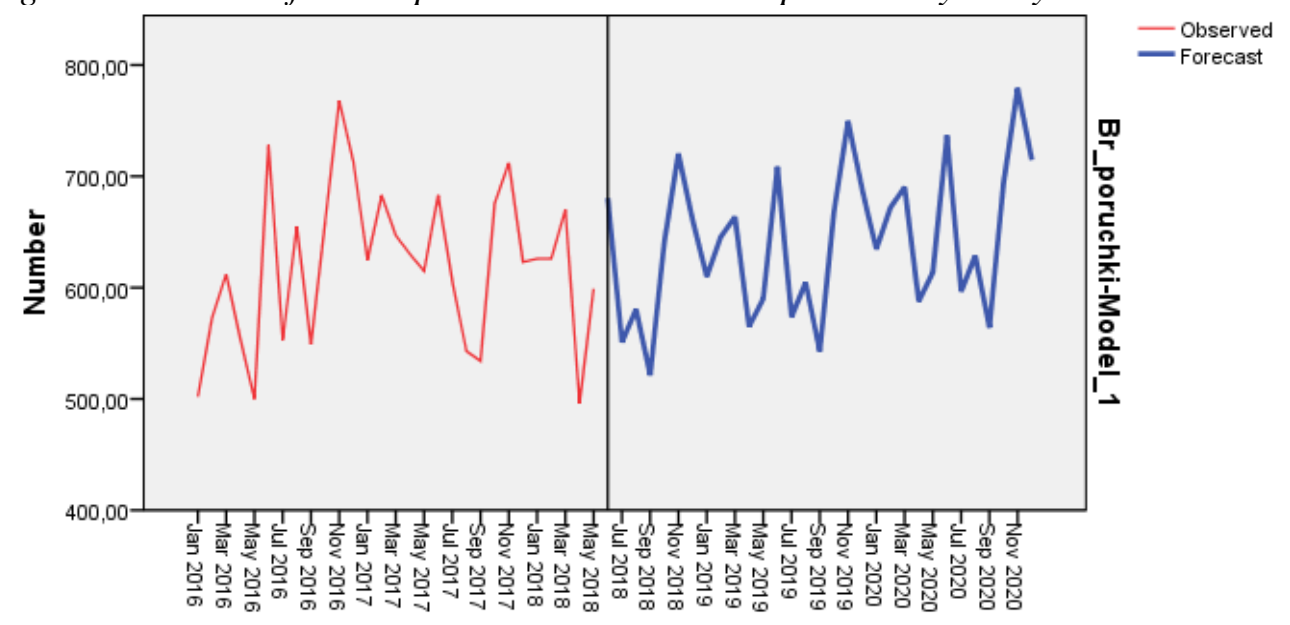

Date

Source: Author's own calculations (2020) 
Figure 5. Number contracts with savings-additive cyclicity

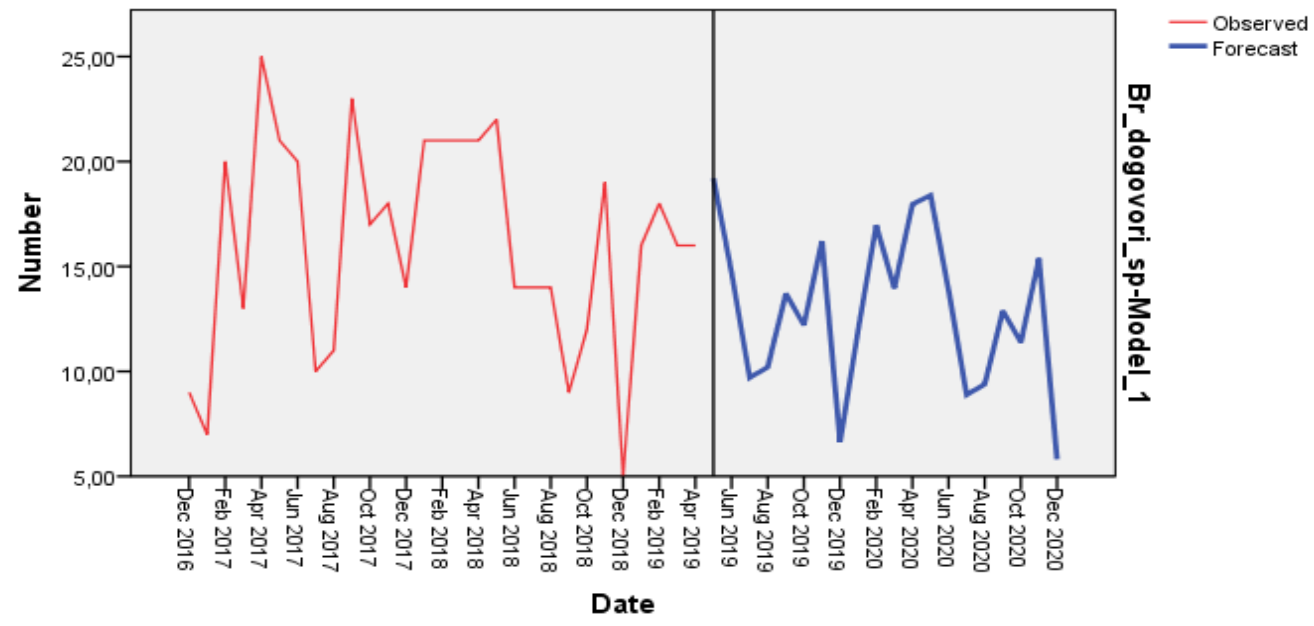

Source: Author's own calculations (2020)

Figure 6. Number contracts with savings - multiplicative cyclicity

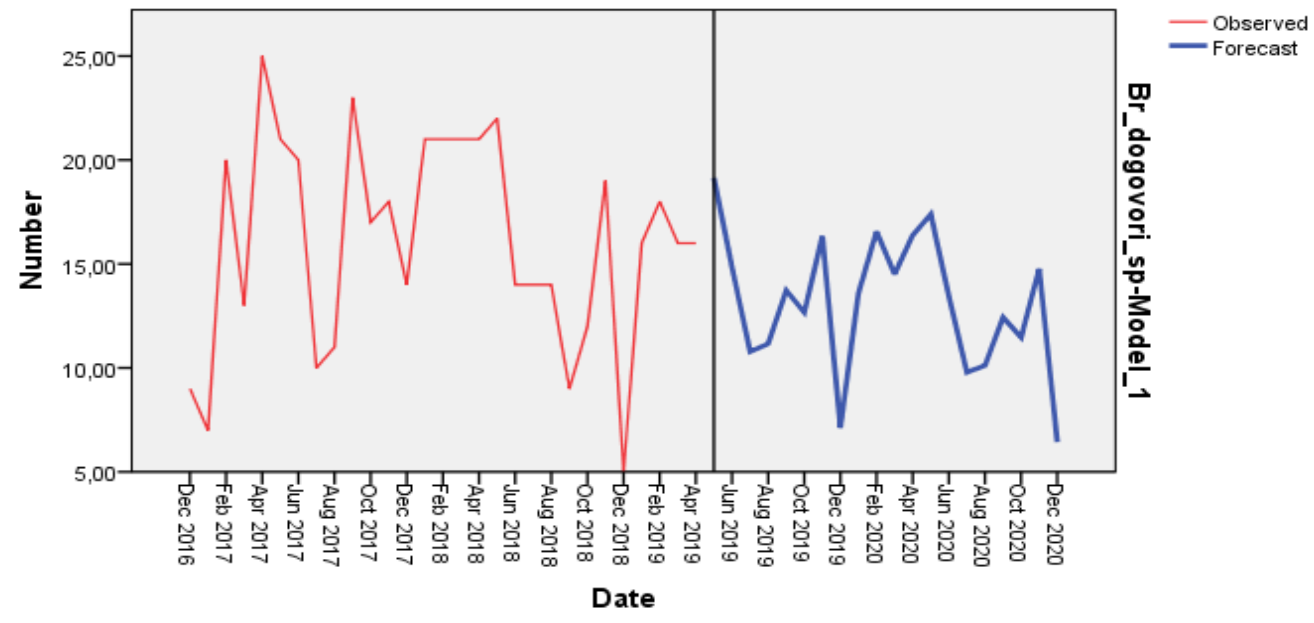

Source: Author's own calculations (2020)

The produced hereby minimums within the forecasting curves are suggested to be used for "GO/NOT GOT" decision points for risk minimization and risk aversion purposes.

\section{Conclusion}

The presented methodology for forecasting of the key indicators in RFI and the RFP processes of the supply chain of the mobile telecommunication operators have not only proved valuable information for the future development of these very same processes. It also produced by the means of the predicted minimums within the forecast curves the necessary "Go / Not go" decision points, that were badly need for analysis and evaluation of the processes and elaborating of the respective decision that were aimed at risk minimization and risk aversion. 


\section{References}

Brown, R. G. (1959). Statistical Forecasting for Inventory Control. McGraw-Hill. Retrieved from http://documents.irevues.inist.fr/handle/2042/28540

Chatfield, C., \& Yar, M. (1988). Holt-Winters forecasting: Some practical issues. The Statistician, 37(2), 129-140. https://doi.org/10.2307/2348687

DeLurgio, S. A. (1998). Forecasting Principles and Applications. Pennsylvania State University: Irwin/McGraw-Hill.

Dimitrov, P. (2010). Short-run forecasting of tourism arrivals in separate sectors of Bulgarian tourism industry. In International Scientific Conference "Alternatives for Development of the Modern Tourism. 378-389.

Dimitrov, P. (2011). Long-run market situation forecasting in tourism. Journal of Science \& Research. 1, 23-33. Retrieved from August 31, 2020 from http://www.bkonk.bg/images/Body_broi_02_final.pdf

Dimitrov, P. (2012). Long-term forecasting of the spa and wellness subsector of the Bulgarian tourism industry. Tourism \& Management Studies, 7, 140-148. Retrieved from https://www.academia.edu/1475952/Long_run_Forecasting_of_Spa_and_Wellness_S ubsector_of_the_Bulgarian_Tourism_Industry

Dimitrov, P. (2013). Long-run forecasting of the number of the ecotourism arrivals in the municipality of Stambolovo, Bulgaria. Tourism \& Management Studies, 9(1), 41-47.

Dimitrov, P. (2020). Експоненциално прогнозиране на туристическите пазари [Exponential Forecasting of the tourism markets]. Sofia, Bulgaria: Avangard-Prima Publishing House.

Dimitrov, P. M., Daleva, D. T., \& Stoyanova, M. (2016). Forecasting the number of Sport Tourism Arrivals in Southwest Bulgaria. Journal of Media Critiques [JMC], 2(8), 173-182. Retrieved from https://www.ceeol.com/search/article-detail?id=470162

Dimitrov, P. M., Daleva, D., \& Stoyanova, M. (2017). Forecasting of the Volume of the SPA and Wellness Tourism Receipts in the South-West Bulgaria. Journal of Spatial and Organizational Dynamics, 5(2), 83-99. Retrieved from https://www.jsodcieo.net/journal/index.php/jsod/article/view/88

Dimitrov, P., Kalinova, M., Gantchev, G., \& Nikolov, C. (2015). Exponential forecasting of the monthly volume of the tourism receipts in Bulgaria. Tourism \& Management Studies 11(1), 104-110.

Dimitrov. P, Krasteva, R., Dimitrov, B., \& Parvanov, P. (2018). Bulgarian tourism and the problem of poverty in Bulgaria. Tourism \& Management Studies, 14(2), 45-52.

Dimitrov, P, Krasteva, R., \& Mirchova, S. (2014). Forecasting of the number of passengers serviced at the Sofia Airport. Contemporary Issues in Tourism \& Management 
Studies. University of the Algarve. 71-88. Retrieved from https://www.ualg.pt/en/node/113050

Dimitrov, P., \& Stoyanova, M. (2015). Long-run forecasting of the spa and wellness tourism development in Bulgaria, Varna. 82-91. Retrieved from http://unicat.nalis.bg/Record/IUV.000032739

Dimitrov, P., \& Stoyanova, M. (2016). Long-run forecasting of the number of international tourism arrivals in Bulgaria. International Scientific Conference "Cultural Corridor Western Transbalkan Road: Cultural Tourism Without Bounderies". South-West University "Neofit Rilski", 125-131.

Gardner, E. S. (1985). Exponential Smoothing: the state of the art. Journal of Forecasting, 4(1), 1-28. https://doi.org/10.1002/for.3980040103

Gardner, E. S. (1987). Chapter 11: Smoothing methods for short-term planning and control. In S. Makridakis and S. C. Wheelright (Ed.), The Handbook of forecasting - A Manager's Guide, (2nd Ed.) (pp. 174-175). New York: John Wiley \& Sons. https://doi.org/10.1016/0169-2070(89)90075-7

Gardner, E.S., \& McKenzie, E. (1985). Forecasting trends in time series. Management Science, 31(10), 1237-1246. https://doi.org/10.1287/mnsc.31.10.1237

Gardner, E.S., \& McKenzie, E. (1988). Model identification in exponential smoothing. Journal of the Operational Research Society, 39(9), 863-867. https://doi.org/10.1057/jors.1988.146

Hamilton, J .D. (1994). Time Series Analysis. Princeton, NJ: Princeton University Press.

Holt, C. C. (1957). Forecasting trends and seasonals by exponentially weighted averages. Carnegie institute of technology. Pittsburgh ONR memorandum.

Hyndman, R., Koehler, A. B., Snyder, R., \& Grose. S. (2002). A state space framework for automatic forecasting using exponential smoothing methods. International Journal of Forecasting, 18(3), 439-454. https://doi.org/10.1016/S0169-2070(01)00110-8

Hyndman, R., Koehler, A. B., Ord, J. K., \& Snyder, R. D. (2008). Forecasting with exponential smoothing: the state space approach. Springer Science \& Business Media.

Hyndman, R. J. (2014). Initializing the Holt-Winters method. Hyndsight - A blog by R. J. Hyndeman. Retrieved from http://robjhyndman.com/hyndsight/hw-initialization/

Ivanov, M. (2007). A try and conclusions from the forecasting of the business processes with the help of time series (a MS PowerPoint presentation in Bulgarian language). Retrieved June 07, 2016 from http://www.nbu.bg/PUBLIC/IMAGES/File/departments/informatics/Izsledvania/Mart in_Ivanov_prolet_2007.pdf 
Ledolter, J., \& Abraham, B. (1984). Some comments on the initialization of exponential smoothing. Journal of Forecasting, 3(1), 79-84.

https://doi.org/10.1002/for.3980030109

Mishev, G., \& Goev, V. (2012). Statistical Analysis of Time Series. Sofia, Avangard-Prima Publishing House.

Pegles, C. C. (1969). Exponential forecasting: some new variations. Management Science, 15(5), 311-315.

Sirakov, S. (1996). Конюнктура и прогнозиране на международните пазари [Conjuncture and Forecasting of International Markets]. Sofia, Bulgaria: Stoilov Publishing House.

Taylor, J. W. (2003). Exponential Smoothing with a damped multiplicative trend. International Journal of Forecasting, 19(4), 715-725. https://doi.org/10.1016/S01692070(03)00003-7

Tashman, L. J., \& Kruk, J. M. (1996). The use of protocols to select exponential smoothing procedures: a reconsideration of forecasting competitions. International Journal of Forecasting, 12(2), 235-253. https://doi.org/10.1016/0169-2070(95)00645-1

Tsay, R. S. (2005). Analysis of Financial Time Series. New York: John Wiley \& Sons.

Winters, P.R. (1960). Forecasting sales by exponentially weighted moving averages, Management Science, 6(3), 324-342. https://doi.org/10.1287/mnsc.6.3.324

Williams, D. W., \& Miller, D. (1999). Level-adjusted exponential smoothing for modeling planned discontinuities. International Journal of Forecasting, 15(3), 273-289. https://doi.org/10.1016/S0169-2070(98)00083-1 


\title{
THE LIABILITY OF THE STATE FOR DAMAGE CLAIMS RESULT OF VIOLATION OF THE EUROPEAN UNION LAW
}

\section{VESELINA KANATOVA-BUCHKOVA ${ }^{1}$}

\begin{abstract}
The article deals with the questions connected with different court procedures on damage claims grounded in State and Municipalities Liability for Damages Act (1989) result of illegal acts of Bulgarian administrative bodies. The article designates the specific issues of the state liability including the issues connected with the new regulation of the court liability for violation of the European Union law.
\end{abstract}

Keywords: damage compensation, European Union law, procedural prerequisites for admissibility, claim.

JEL Codes: K4, K23, K33

\section{Introduction}

The liability of the state through its bodies for unlawful activities is a general principle of the public law, stipulated in the State and Municipalities Liability for Damages Act (SMLDA), (1989). The liability of the state for damage in all cases is non-contractual liability and has an objective character - it arises regardless the culpable behaviour of the official executing public functions. The institute for the non-contractual liability of the state plays a substation role in the protection of the rights of the individuals and legal entities against the illegal acts and actions of the state's bodies as it is an additional tool, along with the possibility of appeal, to control the activities of the state bodies and to claim for damage reparation for violation of subjective rights. It is an expression as well of another main legal principle - that of the legality. State bodies are generally obliged to issues acts and perform actions that do not contradict the "law" in the general sense of the term and when this principle is infringed, the individuals are entitled to claim from the state the reparation of the damage occurred.

The individuals could claim damage reparation when law is infringed. The term "law" covers all binding legal rules, part of the domestic legal system, that regulate the behaviour of the subjects. The European law, in that sense, became an internal part of the domestic legal system since the accession of Bulgaria to the European Union (EU) in 2007, as well as the cornerstone of the European Union institutional law - the liability for breach of the Union law (Gutman, 2016). However, until 2019, the SMLDA (1989) did not provide an explicit rule on the liability of the public authorities for damage caused by infringement of the Union law, similar to the explicit rule of article 1 of the SMLDA (1989) on the liability of the administrative bodies for damages caused by illegal administrative activities or article 2 of the SMLDA (1989) on the liability of the judiciary for damages caused by violation of the defendant's rights. In 2019 an amendment in the SMLDA (1989) was accepted by adoption of article 2c of the SMLDA (1989) that particularly specifies the domestic courts which are competent to resolve disputes arisen from violations of the European Union (EU) law. Although the new article 2c of the SMLDA (1989) could be defined as a procedural norm,

\footnotetext{
${ }^{1}$ Assoc. prof., "Law and History Faculty”, South-West University "Neofit Rilski”, Blagoevgrad. veselina.kanatova@gmail.com

ORCID IDhttps://orcid.org/0000-0002-4389-3529
}

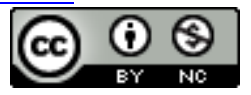

This work is licensed under a Creative Commons Attribution-NonCommercial 4.0 International License 
because it does not specify the preconditions of the liability of the public authorities in cases of inflictions of the Union law, it could serve as a legal basis for damage claims grounded on violation of the European Union (EU) law. Article 2c of the SMLDA (1989) establishes a material ground for the damage claims result of European Union (EU) law infringement because it explicitly links the violation of the Union law to the possibility of bringing an action for damage before the administrative or civil court. Furthermore, with the adoption of article 2c of the SMLDA (1989) the legislator recognizes the right of individuals to hold accountable not only the administrative bodies for illegal administrative acts, but also the administrative court itself for its refusal to comply with Community law or decisions of jurisdictions that are not part of the judiciary, to which the Bulgarian court belongs.

As the State and Municipalities Liability for Damages Act (1989) applies to the liability of the executive and judiciary authorities, the article deals with the responsibility of these authorities, although the violation of the European Union (EU) law could lead to the liability of the legislative in cases where the preconditions of its emergence are met.

\section{Methodology}

The systematic and comparative-legal methods were used in the article. The systematic method reveals the relationship between the different institutes of the liability - the liability of administrative bodies in cases of illegal administrative acts and the liability of the violation of the EU law, as well as the prerequisites of the liability, etc., which are relevant to the subject of current study. The comparative legal method presents the case law of the Court of Justice of the European Union that designates the legal frame of the state's liability and the main conditions of it comes into being.

\section{Legal base of the liability for violating the European Union law}

The institute of the liability of the state bodies, including the administrative ones, is regulated in the State and Municipalities Liability for Damages Act (1989). The SMLDA (1989) lays down the legal basis which specify the types of state bodies, from whose acts or actions the persons can claim compensation for damages, as well as the specific preconditions under which this claim can be realized. The material basis for the liability for damages resulting of the activity of the administrative bodies is established in article 1, paragraph 1 of the Law. The liability of the administrative bodies is an expression of the principle of rule of law that requires supervision of the actions of administration and reparation of damage caused by illegal actions of administration (Adaoglu, 2016). The administrative bodies shall be liable in the cases when they issue an illegal administrative act or perform unreasonable actions by which they cause property or non-property damages to the persons. A specific feature of the liability of administrative bodies is that they could be hold responsible for damage reparation in cases of administrative silence as well (Saddy \& Teixeira, 2016). The liability is expressed in the payment of monetary compensation for damages, the amount of which is determined according to their type - real losses or lost profits (property) or non-property (damage to good name, honour, dignity, etc.). The main feature of the responsibility of administrative bodies for unlawful administrative activities is its objective nature. It is objective liability for another's illegal behaviour, which is subject to the established principles of tortious (non-contractual) liability under article 45 from the Law for obligations and contracts. The liability of the state and municipalities for damages is also defined as "public liability", due to the fact that the damage arise from an illegal exercise of state power as imperium, i.e. in a legal relationship between unequal parties (Elenkov, Lazarov \& Kandeva, 2007). As the liability of the executive arises in the process of exercising administrative activity, it could also be designated as "administrative tort" under the SMLDA (1989). The responsibility of the administrative bodies is an objective responsibility, which occurs regardless of the guilty conduct of the official, who 
issued the illegal administrative act or carried out the unfounded factual action or inaction. In that sense, the damage compensation shall be paid by the administrative body and not by the official who directly issued the illegal administrative act or carried out the unfounded factual action. The personal liability of the official towards the administrative body, sentenced to compensate the damages, shall be realized according to the type of legal relationship with the body and its assessment whether and in what way to punish the official. In case the legal relationship between the official and the administrative body is labour, his responsibility towards the employer is realized by the Labour Code (1986) and the established in the same rules for property and disciplinary liability of the employee, and when the official is a state employee, his responsibility to the appointing authority is in accordance with the rules of the Civil Servant Act (1999) and the disciplinary sanctions provided for therein.

The main precondition for the occurrence of the objective responsibility of the administrative bodies is the illegality of the administrative act or factual action or inaction. The illegality is established by issuing a court decision on an appeal of the affected persons, which annuls the administrative act or the effect of the administrative action or inaction. In this regard, the main prerequisite for engaging the responsibility of the administrative bodies under article 1 of the SMLDA (1989) is the preliminary annulment of the administrative act or factual action or inaction. The claim for damages from illegal administrative activity shall be filed, according to the second paragraph of article 1, before the administrative court. The administrative court rules according to the proceedings for compensations, established in the Administrative Procedure Code (2006).

Article 1 of the SMLDA (1989), on the other hand, covers the non-contractual liability only of the administrative and no other state bodies, such as the administrative court. Until the amendment of the SMLDA (1989) in 2019, individuals had no other line of defence against incorrect court decisions than to challenge them before the second instance, whose decision is final and not subject to appeal.

In 2019 the Bulgarian legislator accepted an amendment in the SMLDA (1989) that has established the legal regulation of the procedure for claims against the administrative bodies as well as the court authorities for damages resulting of substantial infliction of the European Union law. Article 2c of SMLDA (1989) was accepted named "Procedure for dealing with claims against the state for damages for violation of the European law". For the first time the legislator connects the liability for damage not only to administrative authorities but also to court authorities. At the same the law expands the liability to cases where a sufficiently serious infringement of the Union law is executed and thus introduces a new legal ground of the noncontractual liability of the state bodies. Article $2 \mathrm{c}$ could be defined as procedural norm as it deals with the procedural questions of the damage claims for violation of the European union law which, when result of the administrative acts and court decisions of administrative courts, are filed before the administrative or Supreme Administrative Court and when result of civil court authorities are held before the civil courts according the Civil Procedure Code (2008).

The amendments in the State and Municipalities liability act follow a Judgment of the Court of Justice of the European Union C-571 - Kantarev (2016) on request for a preliminary ruling of Varna Administrative court (Bulgaria) regarding a damage claim against the Bulgarian National Bank (BNB) under article 1 of the SMLDA (1989).

The request had been made in proceedings between Mr Nikolay Kantarev and the Bulgarian National Bank concerning the harm that Mr. Kantarev claimed to have sustained due to the late payment of the guaranteed deposit on the basis of deposits made to a current account opened with Commercial Trade Bank (CTB) which became unavailable. Mr. Kantarev claimed that the Bulgarian national bank (BNB) failed to comply with the obligation to apply EU law with direct effect in the field of repayment of guaranteed deposits, as the BNB had in relation to Directive 94/19/EC of the European Parliament and of the Council of 30.05.1994 on Deposit 
Guarantee Schemes (1994). In the preliminary request the administrative court asks about the procedure that should be followed when deciding on the liability of the bank - whether it should be the procedure according to the SMLDA (1989) or the procedure according to the Obligation and Contracts Act (1950) having in mind the different legal prerequisites of the administrative and civil damage liability. According to the SMLDA (1989), specifically article 1, claim against state or administrative body could be filed only when the administrative act is previously annulled by the court, while this prerequisite under the Obligation and Contacts act is not stated. The question of the Varna administrative court had been provoked by the lack of national legislation determining the procedure for examining damages claims for breaching of EU law and established criteria for distinguishing the jurisdiction of the court - the administrative or general civil court. The request for the preliminary ruling was provoked and from the inconsistent case - law of the Bulgarian courts regarding the jurisdiction of the civil or administrative court's ruling on actions for damages for harm caused by a breach of EU law. In the previously stated case, the Bulgarian National Bank missed to fulfil its obligations to guarantee the deposits in the stated terms which miss action was not annulled as illegal, but the BNB violated EU law through the said inactivity, as a result of which the plaintiff suffered property damage. Firstly, the Court noted that the principle of State liability for loss and damage caused to individuals as a result of breaches of European Union law for which the State can be held responsible is inherent in the system of the treaties on which the European Union is based. "Thus, it is for each Member State to ensure that individuals obtain reparation for loss and damage caused to them by non-compliance with EU law, whichever public authority is responsible for the breach and whichever public authority is in principle, under the law of the Member State concerned, responsible for making reparation"'2. Furthermore the Court, as to the conditions for incurring the non-contractual liability of the State to make reparation for loss and damage caused to individuals as a result of breaches of EU law, rules that a right to reparation arises when three main prerequisites are at hand: if the rule of EU law infringed confers rights to the individuals, if the breach of that rule is sufficiently serious and if there is a direct causal link between that breach and the loss or damage sustained by the individuals. The Court concluded that the principle of effectiveness requires the national legislation to ensure the individuals the access to court that does not require additional conditions as the three general conditions pointed by the Court. In that respect, the preliminary annulment of the miss activity of the Bulgarian National Bank should not be a prerequisite of the damage claim in the case, or the payment of the $4 \%$ state tax as the Obligation and Contracts Law (1950) requires. The Court ruled that the state liability for reparation of damage result of breach of the European Union law should be held according the procedure in SMLDA (1989).

The judgment of the Court of Justice of the European Union (CJEU) in Kantarev (2016) became the reason for the establishment of article 2c in the Liability of the State and Municipalities for Damage act, which despite of its title reference as to the procedure to be followed when filing claims against the administrative or court authorities for violation of the EU law, is the material legal ground for such claims. Article 2c of the SMLDA (1989) enshrines the basic principle of the non - contractual liability of Member States for damage caused to individuals by infringements of Community law of the European Union, established in the case law of the Court of Justice of the European Union (CJEU).

The institute of non-contractual liability of the state for damages for violation of EU law has been consistently introduced in a number of decisions of the CJEU, which assume that the non-contractual liability of the state derives from the principle of loyal cooperation established in Art. 4, $\S 3$ Treaty of EU (2012), and is inherent in the system of treaties on which

\footnotetext{
${ }^{2}$ See judgment of 28 July 2016, Tomášová, C 168/15, EU:C:2016:602, paragraph 22 and the case-law cited, 2016)
} 
the Union has been founded ${ }^{3}$. It is considered that the liability of a Member State for damage caused by an infringement of Community law is linked to the need to ensure the effective exercise of the rights conferred on individuals by Community law and their protection. It is the protection of the rights conferred on individuals by Community law that requires them to be able to obtain compensation from national courts for damage caused by an infringement of those rights, including where the infringement results from a final judicial act.

Article 2c from the SMLDA (1989) introduces the institute of non-contractual liability of the state for damages from violation of EU law in the national legislation as an independent ground for engaging the liability of the state through its bodies for damages, among other grounds under the law. Despite the imprecise legislative technique that refers to the general ground of the state responsibility under article 1 of the SMLDA (1989), the provision of article $2 \mathrm{c}$ regulates a new special substantive legal basis for liability for damages from administrative activity, along with article 1 of the SMLDA (1989), when the damages are caused by a sufficiently significant breach of European Union (EU) law.

Prior to the amendment of the SMLDA (1989), the grounds for engaging the state's liability for damages from violation of EU law were derived from the principle of loyal cooperation (Art. 4, $\S 3$ of the Treaty of EU, 2012). Member States are obliged to take all necessary measures, general and specific, to ensure the fulfilment of their obligations under the Treaties or by acts of the institutions of the Union, to assist the Community in achieving its objectives and to refrain from any measures which might jeopardize those objectives. A number of specific obligations derive from the general principle of loyal cooperation, including for national courts, some of which are stated in the Treaties and others derived from the case law of the Court of Justice. The institute of non-contractual liability of a Member State for damage caused by infringement of the Union law is considered by the researchers to have arisen following the Judgment of the Court of Justice of the European Union (CJEU) in the Francovich (1991) case, from which date it became part of EU law and the basis for engaging the responsibility of the state through its bodies. The Judgment of the CJEU in the Francovich (1991) case has been defined as a legal norm, created exceptionally by the Court of Justice, further developed in the subsequent case law of the Court of Justice of the European Union (CJEU), which has been the basis for engaging the non-contractual liability of the state for damages for violation of EU law, not article 4, $\S 3$ of the Treaty of the European Union (TEU) (Kostov, 2013). Furthermore, the Judgment of the CJEU in Francovich (1991) case has been considered to established a doctrine in the sphere of the non-contractual liability of the state bodies (Kostov, 2017). Regardless which view of the basis of the non-contractual liability of the state will be shared, with the amendments to the SMLDA (1989) in 2019 and the introduction of the provision of article $2 \mathrm{c}$ overcomes the search for a legal basis in the domestic legislation for claims for damages for violation of EU law.

Article $2 \mathrm{c}$ applies independently from the general provision of article 1 of the SMLDA (1989) that states the general principle of the damage liability of the state through its administrative bodies in cases of unlawful administrative activities. Article 1 of the SMLDA (1989) is the legal ground of the liability of the administrative bodies for damages arisen from illegal administrative activity. The main condition for damage claims under article 1 is the annulment of the administrative act because of its conflict with the law. There is a contradiction, in that sense, in the norm of $2 \mathrm{c}$ when referring to article 1 of the SMLDA (1989) saying that when the damages are caused by a sufficiently significant violation of the EU law

\footnotetext{
3 in that sense are: Judgment of 19 November 1991 С 6/90 и С 9/90 (Francovich and others), Recueil, c.I 5357; Judgment from 5 May 1996 г. С 46/93 и С 48/93 (Brasserie du pêcheur и Factortame), Recueil, c.I 1029; Judgment C-392/93 British Telecommunications (1996), c. I-1631; Judgment C-5/94 Hedley Lomas (1996), c.I2553; Judgments on joined cases C-178/94, C-179/94, C-188/94, C-189/94 and C-190/94 Dillenkofer and Others (1996), c. I-4845 and others
} 
under article 1, the procedure for consideration of the claim is that under the Administrative Procedure Code (2006). The second paragraph of article 1 explicitly regulates the procedure for consideration of claims for damages from illegal administrative activity, due to which the repeated reference to the Administrative Procedure Code (2006) in article 2c is not necessary. Moreover, the ground for liability for damages for breach of European Union (EU) law is not related to the annulment of the act, action or omission resulting from an administrative activity as illegal. If a court decision rejects the challenge against the administrative act its legality is confirmed and the ground of article 1 of the SMLDA (1989) does not occur. At the same time, however, if the court decision is rendered in violation of EU law, which is sufficiently substantial and from which the persons bound by the decision suffer damages, then there will be ground for engaging the state's liability for damages under article 2c of the SMLDA (1989). The grounds of article $2 \mathrm{c}$ may also arise in cases when the administrative act has entered into force as unappealed, but contradicts EU law, which has been related to damages to its addressees. That is why the reference to article 1 of the SMLDA (1989) in the norm of article $2 \mathrm{c}$, in addition to not being necessary, confuses the regulation of liability for damages for violation of EU law, which, as indicated, is a ground different from the general hypothesis of article 1 of the Liability of the SMLDA (1989).

Subjects of liability under article 2c of the Liability of the SMLDA (1989) are the administrative authorities, whose act, which entered into force as unappealed or excluded from judicial review by a special law, violates a rule of EU law or the administrative court, respectively the Supreme Administrative Court, whose court decision rejects the challenge of an administrative act and thus infringing EU law.

The liability of the administrative bodies and administrative courts for damages caused by violation of the European Union (EU) law is an objective liability that arises regardless of whether the actions of the administrative body or the court were intentional in connection with the application of European Union (EU) law. The rule is explicitly established in the case law of the Court of Justice of the European Union (CJEU) and repeatedly mentioned in the judgments of the CJEU. In that sense the Court of Justice of the European Union (CJEU) in case C-429/09 (Fus) states that: “... although certain objective and subjective circumstances which may be linked within the national legal system to the concept of culpable unlawful conduct are relevant in assessing whether or not a breach of European Union law is sufficiently serious in the light of the case-law (...), the obligation to compensate individuals for damages cannot be made conditional on a concept of culpable unlawful conduct which goes beyond that of a sufficiently serious breach of European Union law."

The principle of non-contractual liability applies in any case where a Member State infringes Community law, irrespective of which institution of the Member state is responsible for that breach. In that regard the Court of Justice of the European Union (CJEU) in C-224/2001 (Kobler) judged that in international law a State which incurs liability for breach of an international commitment is viewed as a single entity, irrespective of whether that breach which gave rise to the damage has been attributable to the legislature, the judiciary or the executive. That principle has to apply a fortiori in the Community legal order since all State authorities, including the legislature, are bound in performing their tasks to comply with the rules laid down by Community law which directly govern the situation of individuals. The mentioned judgment of the CJEU answers the request of a preliminary ruling on the question whether the principle of the non-contractual liability of the Member States is also applicable where the infringement of the EU law stems from a decision of a court adjudicating at last instance and whether, if so, it is for the legal system of each Member State to designate the court competent to adjudicate on disputes relating to reparation of the damage. The Court ruled that: "In the light of the essential role played by the judiciary in the protection of the rights derived by individuals from Community rules, the full effectiveness of those rules would be 
called in question and the protection of those rights would be weakened if individuals were precluded from being able, under certain conditions, to obtain reparation when their rights are affected by an infringement of Community law attributable to a decision of a court of a Member State adjudicating at last instance (...) that the principle of res judicata does not preclude recognition of the principle of State liability for the decision of a court adjudicating at last instance" (Kobler, C-224/2001)

Practically, that decision affirmed the principle of State liability for damage caused by infringements of Community law by final judgments, which liability is fully compatible with the principle of res judicata and the independence of the judiciary. In that regard, the decision emphasized on the differences between the two proceedings, the damages proceedings against a Member State and the proceedings in which the final judgment was given, as to the purpose and the parties. "The applicant in an action to establish the liability of the State will, if successful, secure an order against it for reparation of the damage incurred but not necessarily a declaration invalidating the status of res judicata of the judicial decision which was responsible for the damage. In any event, the principle of State liability inherent in the Community legal order requires such reparation, but not revision of the judicial decision which was responsible for the damage ${ }^{4} . "$

\section{Conditions of the damage liability of executive and judiciary for infringement of the EU law}

The State and Municipalities Liability for Damages Act (1989) does not establish conditions of the damage liability of the executive and judiciary for violation of Union law. In fact, the legal regulation of liability for infringement of European Union law is limited to the new provision of article $2 \mathrm{c}$, which designates only the procedure for filing the claim for damages, but does not indicate the material prerequisites of the claim. The lack of material regulation, in that sense, requires the preconditions of the damage claim to be derived from the case law of the Court of Justice of the EU. In numerous decisions the CJEU has ruled that the liability of the state for infringement of the law of the union arises when three general conditions are at stake, namely - infringement of a Union rule which has a direct effect and confers rights for the individuals, the breach of the norm is sufficiently substantial and there is a causal link between the infringement and the damage suffered.

These three conditions are sufficient to involve the State's liability for infringement of EU law. The Member States are not entitled in their national legislation to lay down additional requirements for the State's liability for damages, such as the prior annulment of the act, the action or the inaction, exhaustion of domestic remedies or filing for preliminary administrative proceedings for damage reparation from court decision before the Supreme Judicial Council.

\subsection{Breach of EU law}

The first condition for engaging the liability of the administrative bodies or court to repatriate the damage arose from the administrative act or service or the final court decision is the violation of the EU law. The breach of law is an obligatory condition of the liability as the state bodies could not be hold responsible for originally defined as lawful and justified conduct (Sonnekus, 2017).

The sources of Union law have been differentiated as primary and secondary sources of legal norms - primary and secondary law, which stay in normative hierarchical dependence. At the top of the normative hierarchy is the primary law, which covers the treaties - the Treaty on European Union, the Treaty on the Functioning of the European Union and its annexes, the Treaty of Lisbon, the Charter of Fundamental Rights as well as the general principles of Union law. The international agreements concluded by the EU with third countries or organizations

\footnotetext{
${ }^{4}$ See CJEU in C-224/2001 (Kobler)
} 
under Art. 261, $\S 1$ Treaty on the Functioning of the European Union (TFEU) 2012 are subject to primary law and are also part of Union law. Secondary law covers the legal acts of the Union listed in article 288 of the TFEU - regulations, directives, decisions, recommendations and opinions. Binding legal force has the regulations, directives and decisions. Recommendations and opinions are not a source of rights or obligations, but provide guidance on the interpretation and content of Union law.

The regulation is generally applicable and binding in its entirety. It shall apply directly in all Member States from its entry into force, on the date specified in the Regulation or, if no specific date is specified, on the twentieth day following that of its publication in the Official Journal of the European Union, without the need to implement it into national law.

The Directive has been binding on all the Member States to which is addressed as to the result to be achieved, but leaves it to the national authorities to choose the forms and means of its implementation. The national legislature must adopt an act transposing the directive into national law, bringing national legislation in accordance with the objectives set out in the directive. The individuals are subject to the relevant rights not directly from the directive but by the national law that implemented it. The principle of loyal cooperation obliges Member States to transpose directives in a way that ensures the effectiveness of EU law. Therefore, it is considered that incorrect transposition of a directive leads to its direct effect in the Member State, if, in addition, its provisions are sufficiently precise and clear and create rights for individuals. The directive applies directly also in cases where not implemented at all in the stated terms into national law and has clear provisions which create rights to the individuals. In these cases, the individuals could rely directly on the provisions of the directive before the administrative authorities or court and the breach of the directive gives rise to the right for damage claim under article 2c of the SMLDA (1989).

The decision is binding in its entirety when it designates specific addressees - Member States, natural or legal persons. However, it is binding only on them and provides for measures relating to the specific situation of the Member States or persons concerned. The individual may assert the rights conferred by a decision addressed to a Member State only if it has adopted an act transposing the decision or it is sufficiently clear, creates rights and has not been transposed into national law.

EU law is an integral part of the legal systems of the member states. The violated norm may be part of both the primary and the secondary legislation, may have direct effect or may not be directly applicable. Article 291 (1) of the Treaty on the Functioning of the European Union (2012) obliges Member States to take all necessary measures under national law to implement legally binding Union acts. Furthermore, is an obligation of the court to apply EU law in cases where the national law is inconsistent with the requirements of Union law. The obligation to apply directly the EU law when the national law does not meet the European standards of protection the rights of the individuals, despite the court, have and the administrative authorities. The obligation for administrative authorities to apply EU law is reciprocal to the right of individuals to invoke binding rules, including directives and decisions with direct effect.

The priority of European Union law over national law and its direct effect do not release Member States from the obligation to repeal a national law which does not comply with Community law. This is because maintaining it creates uncertainty in subjects about the ability to rely on it. On the other hand, administrative bodies and the court are obliged to apply the Community legal order when an internal norm contradicts it, regardless of its effect until its repeal, as well as regardless of the type of norm - whether it is legal or by-law. To the greatest extent, the rule of observance of the principles of Community law applies to the administrative court, which is obliged to ensure the full effect of these rules. The national court responsible for the application of the rules of Community law within its jurisdiction is required to ensure 
the full operation of those rules, leaving any provision of national law contrary to them, if necessary on its own initiative, without demanding or waiting for the repeal of such a provision by legislative or other constitutional order ${ }^{5}$.

Moreover, the decisions of the CJEU on the interpretation of Community law, rendered on references for a preliminary ruling, have a declaratory effect, which leads to the fact that they operate from the entry into force of the interpreted rule, i.e. have retroactive effect, unless the court limits the effect of the decision in time. "A preliminary ruling does not create or alter the law, but is purely declaratory, with the consequence that in principle it takes effect from

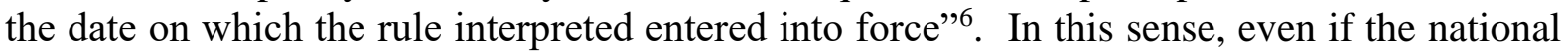
rule is not repealed, the later judgment of the CJEU, which finds a conflict with Community law, is a ground for it not to be applied by both the administrative authorities and the court. That is why the application of an internal norm, which has not been repealed, but contradicts Community law, will constitute a violation of EU law within the meaning of article $2 \mathrm{c}$ of the Law on Liability of the State and Municipalities for Damage and will lead to the opportunity for damage claims by private individuals.

The scope of the violation of a norm of the European Union (EU) law also includes cases of non-compliance with the case law of the Court of Justice of the European Union, as well as those in which the court was obliged to make a preliminary reference, the answer to which depends on resolving the administrative law dispute, but did not do so. In its practice, the Court of Justice of the European Union (CJEU) has held that failure of the court to make a reference for a preliminary ruling on the application of European Union law, where it is necessary to resolve a dispute, constitutes a breach of the primary rule of Art. 267 of the Treaty on the Functioning of the European Union (TFEU, 2012) and infringes the European Union law. Whether this violation is sufficiently significant is already a matter of judgment by the court which considers the claim for damages under article 2c of the SMLDA (1989).

\subsection{The term "significantly substantial breach" of EU law}

Article 2c of State and Municipalities Liability for Damages Act (1998), on second place, demands the infringement of the EU law to be of a "sufficiently substantial" nature. The assessment of whether the violation is sufficiently substantial belongs to the court hearing the claim for damages. According to the CJEU case-law, such a breach implies a manifest and grave disregard by the Member State for the limits set on its discretion. The factors which may be taken into consideration in that regard include, inter alia, the clarity and precision of the rule breached, the measure of discretion left by that rule to the national authorities, whether any error of law was excusable or inexcusable, whether the infringement and the damage caused was intentional or involuntary, or the fact that the position taken by an EU institution may have contributed towards the omission, adoption or retention of national measures or practices contrary to EU law.

In any case where there has been a manifest breach of Court of Justice of the European Union (CJEU) practice, the infringement of Community law is considered to be sufficiently serious.

These criteria have been identified as guiding the practice of the CJEU in dealing with disputes concerning the direct effect of rules of directives which confer rights, in so far as regulations are legally binding regulations applicable under national law. Therefore, some of the criteria are the clarity of the norm of the directive, as well as the scope of the operational autonomy of the member states with a view to transposing the measures established in it. Community law does not define the limits of the discretion of the Member States in choosing the measures when implementing in the national law the EU directives. Undoubtedly, the

\footnotetext{
${ }^{5}$ See Judgment of the Court of Justice of the European Union (CJEU) on case C-106/77 (Simmenthal)

${ }^{6}$ See Judgment of the Court of Justice of the European Union (CJEU) on case C-2/06 (Willy Kempter)
} 
choice of a decision should be in accordance with the general principles of the law of the Union as principles that respect freedom, democracy and the rule of law. The Treaties contain few references to the principles of Union law which are established and developed mainly in the case law of the Court of Justice. These are the principles of legal certainty, institutional balance, justified legal expectations, proportionality, legitimacy, the principle of equal treatment and others. The settled case-law of the Court of Justice of the European Union (CJEU) accepts, in the absence of Community rules in one field, it is for the domestic legal system of each Member State to designate the courts and tribunals having jurisdiction and to lay down the detailed procedural rules governing actions for safeguarding rights which individuals derive from Community law, provided, first, that such rules are not less favourable than those governing similar domestic actions (principle of equivalence) and, secondly, that they do not render practically impossible or excessively difficult the exercise of rights conferred by Community law (principle of effectiveness) ${ }^{7}$.

In this respect, compliance with the principles of Union law has emerged as one of discretion limits of the Member States. If a fundamental principle of Union law is infringed in the act transposing a directive, there is a breach of EU law. Whether this violation will be qualified as sufficiently significant is a matter for the court which hears the case on a claim for damages under article $2 \mathrm{c}$, whose decision will take in mind the circumstances of the specific case and the justification of the violation in view of the protection and predominance of the public over the private interest. There may be cases where specific principles are not applied or are applied, but to a lesser extent, given the need another legally defensible principle of both Union and domestic national law to prevail.

\subsection{Direct link between the damage and the EU law breach}

The third prerequisite of the claim for damages under article $2 \mathrm{c}$ is the existence of a causal link between the violation and the occurred damages. The link should be direct - the administrative act or the court decision that breach the law of the Union should be the main reason for the damage. The causal link is present when the act is a condition that causes negative consequences in the sphere of the injured person, which condition is a condition sine qua non for the damage, i.e. a condition without which the damage would not have occurred. Conversely, there is no causal link where the damage would have occurred in the legal sphere of the injured party and if the administrative act or court decision had not been issued. The damage, in this sense, should naturally and objectively result from the act and not be its accidental consequence. The existence of the casual link in all cases is a task of the national court to determine (Vehovec, 2012). In practice, the absence of a direct causal link in many cases is a ground for the rejection of the damage reparation claim by the court.

The three abovementioned conditions are sufficient for the individual to file a damage claim against the administrative authority or administrative court and engage their liability for EU law violation under article $2 c$ of the SMLDA (1989).

In the case before the court the applicant must indicate the provision of breached Community law which he considers to have direct effect and confers rights and to prove the occurrence of the damage claimed. On the other hand, the plaintiff is not required to prove or refer to the case law of the Court of Justice. The assessment of the existence of the case law of the Court of Justice of the European Union (CJEU), which is applicable in the concrete dispute, belongs to the administrative court hearing the claim for damages. The assessment of whether there is a breach of a rule which directly confers rights and whether that breach is substantial also belongs to the administrative court.

\footnotetext{
${ }^{7}$ See Judgment of the Court of Justice of the European Union (CJEU) on case C-2/06 (Willy Kempter).
} 


\section{Conclusion}

The amendment of the Law on Liability of the State and Municipalities for Damages (1998) in 2019 and the acceptance of article 2c explicitly established the legal basis for liability for damages for violation of EU law. Among the responsible subjects, along with the administrative bodies, is now the administrative court. Apart from the correct application of the law in the broadest sense of the word, including European Union (EU) law, the court must now observe the practise of the Court of Justice of the European Union (CJEU), which makes its task to resolve the dispute correctly and fairly even more difficult and responsible. On one hand, the designated amendment of the law has increased the scope of protection of personal rights of the individuals and legal entities entitling them to claim reparation from final court judgment whose legal strength applies directly in their legal sphere and could not be repealed.

On the other hand, with the adoption of article 2c of SMLDA (1989) another basic problem of the damage claims, resulting of the infringement of the Union law, was solved the problem connected with the competent court to resolve the dispute. The regulation is already clear - when the damages are caused by an administrative body or a court decision of the administrative court, the claim is brought before the administrative or Supreme Administrative Court, following the procedure established in the Administrative procedure code and when the damages are caused by a civil court, the claim is brought before the civil court under the procedure of the Civil Procedure code. 


\section{References}

Adaoglu, H. S. (2016). Actions for Damages in EU Law: A Comparative Analysis of the Liability of EU Institutions and the Liability of Member States. AMME IDARESI DERGISI, 49(2), 79-104.

Elenkov, A., Lazarov, K., \& Kandeva, E. (2007). Коментар на Административнопроцесуалния кодекс [Comment on the Administrative Procedure Code]. Сиби, София. Retrieved from https://tinyurl.com/y8hcpzz2

Gutman, K. (2016). Liability for breach of EU law by the union, member states and individuals: damages, enforcement and effective judicial protection. Research Handbook on EU Institutional Law. Edward Elgar Publishing.

Kostov, St. (2013). Правната квалификация на иска за обезщетяване на вреди, причинени от Република България в нарушение на правото на Европейския съюз [The legal qualification of the claim for damage reparation again the Republic of Bulgaria for infringement of the European Union law], Адвокатски преглед, 10. Retrieved from https://www.vas.bg/p/A/d/Adv10_2013_2-2058.pdf.

Kostov, St. (2017). Извъндоговорната отговорност на ЕС и на държавите членки [The non-contractual liability of the European Union and the Member States]. Сиби, София. Retrieved from https://tinyurl.com/y 7 yfmql8

Saddy, A., \& Teixeira, A. V. (2016). State liability for inactivity of the Public Administration: a specific study of administrative silence. A\&C-REVISTA DE DIREITO ADMINISTRATIVO \& CONSTITUCIONAL, 16(65), 109-133.

Sonnekus, J. C. (2017). Liability of the State for Damage Caused by Lawful/Rightful Conduct of State Organs. JS Afr. L., 225. Retrieved from https://tinyurl.com/y9eu2q8b

Vehovec, M. T. (2012). Cause of Member State Liability, The. Eur. Rev. Private L., 20, 851. Retrieved from https://tinyurl.com/y9bz3usy

\section{Regulations and Decisions}

Administrative Procedure Code (APC, 2006). Retrieved from http://shorturl.at/eiTU6.

C-224/2001 (Kobler). Retrieved from https://tinyurl.com/yd9gozf5

C-429/09 (Fus). Retrieved from https://tinyurl.com/y7xg2ddh

Civil Procedure Code (2008). Retrieved from https://tinyurl.com/y7jy8184

Civil Servant Act (CSA, 1999). Retrieved from https://tinyurl.com/ydblc5fn

European Union, The European Parliament and the Council of the European Union. (1994). Deposit-guarantee schemes. (Directive 94/19/EC) Retrieved from https://tinyurl.com/ya5furkp 
Judgment of the Court of Justice of the European Union /C-571/2016 - Kantarev. Retrieved from https://tinyurl.com/ycwjujyj

Judgment of 19 November 1991 C 6/90 and C 9/90 (Francovich and others), Recueil, c.I 5357. Retrieved from https://tinyurl.com/yb7arymm

Judgment of 5 May 1996 г. С 46/93 and C 48/93 (Brasserie du pêcheur и Factortame), Retrieved from https://tinyurl.com/y83kgryp

Judgment C-392/93 British Telecommunications (1996). Retrieved from https://tinyurl.com/y6wu5ns8

Judgment C-5/94 Hedley Lomas (1996), Retrieved from https://tinyurl.com/yc7jn7ck

Judgments on joined cases C-178/94, C-179/94, C-188/94, C-189/94 and C-190/94

Dillenkofer and Others (1996). Retrieved from https://tinyurl.com/ya3lhjux

Judgment of 28 July 2016, Tomášová, C 168/15, Retrieved from https://tinyurl.com/y8f8ku3g

Judgment on case C-106/77 (Simmenthal). Retrieved from https://tinyurl.com/y8nn5y7y

Judgment on case C-2/06 (Willy Kempter). Retrieved from https://tinyurl.com/y79cmclh

Labour Code (1986). Retrieved from https://tinyurl.com/ybrhwqjw

State and Municipalities Liability for Damages Act (SMLDA). (1989) Retrieved from https://tinyurl.com/y9v3rltc

Obligation and Contracts Act. (1950). Retrieved from https://tinyurl.com/y79dtgk6

Treaty of EU (2012). Retrieved from https://tinyurl.com/y3hyjjlw

Treaty on the Functioning of the European Union (TFEU) (2012). Retrieved from https://eurlex.europa.eu/legal-content/EN/TXT/?uri=celex\%3A12012E\%2FTXT. 